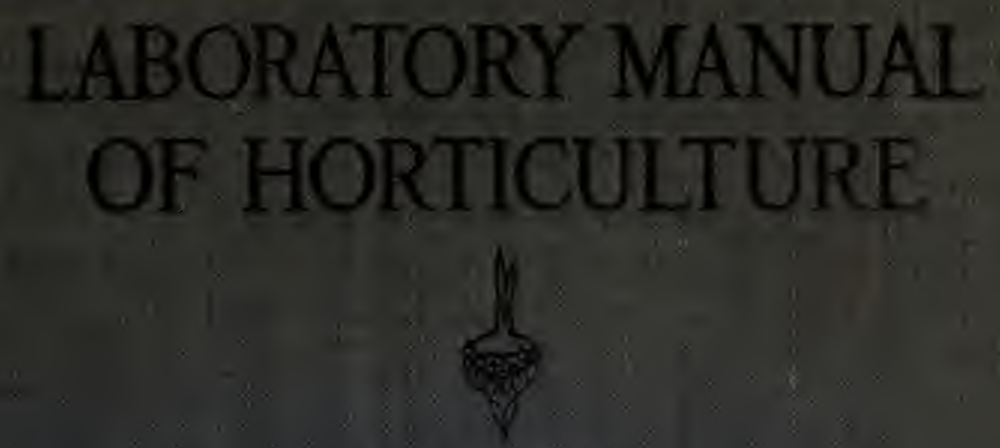

HOOD 

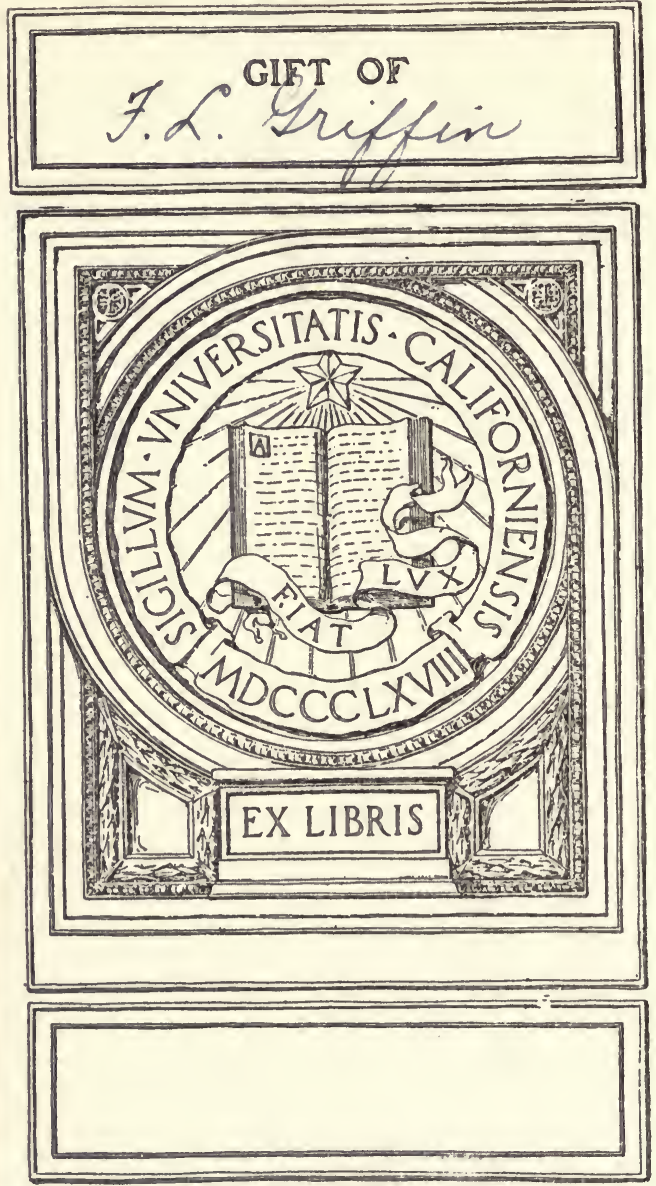
<smiles>C1=C[C@@H]2CCC[C@@H]12</smiles> 


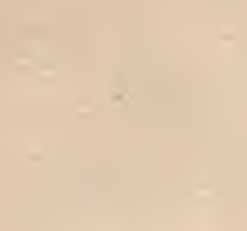

tf 


\title{
LABORATORY MANUAL OF HORTICULTURE
}

\author{
WITH ILLUSTRATIONS OF \\ METHODŚ, EQUIPMENT, AND APPARATUS
}

BY

GEORGE W. HOOD

ASSOCIATE PROFESSOR OF HORTICULTURE

UNIVERSITY OF NEBRASKA

GINN AND COMPANY

BOSTON - NEW YORK - CHICAGO - LONDON

ATLANTA DAllas - COLUMBUS - SAN FRAxCisco 

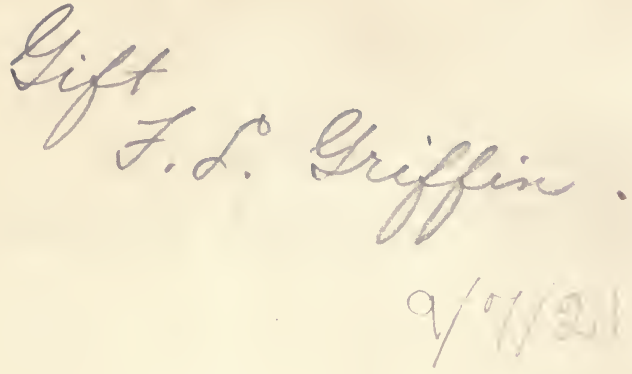

COPY RIGHT, 1915, BY

GEORGE W. HOOD

ALL RIGHTS RESERVED

215.8 


\section{PREFACE}

This manual contains the exercises that have been given in connection with the work in General Horticulture at the Ohio State University, Michigan Agricultural College, and University of Nebraska.

It is a modest attempt to fill a place that, for a long time, has seemed to be vacant. The aim is to give the student an outline by which he can better grasp some of the fundamental principles of horticulture, and an opportunity to learn by actual experimentation and observation the reasons for certain necessary operations in horticulture.

It is the object of this manual to give explicit directions for every detail of the work. In certain exercises it may be impossible for the student to do all the tasks outlined, but only such parts as are suited to the conditions under which the student is working should be attempted. This must be determined by the instructor, who, it is hoped, will select those exercises that are most practicable for his class.

The drawings asked for and the questions raised in the several exercises are designed to bring out fundamental principles and important points as well as to fix firmly in the mind of the student the necessity of careful and systematic work.

The author has made use of suggestions found in other works, and has endeavored to bring together the information that will be the most helpful to the student, and to present it in such a manner that it will be of value to the beginner. He makes no claim of completeness for this outline: only such exercises have been included as seem best adapted to a general course in horticulture. Most of these exercises can be done in the laboratory, but after the fundamental principles have been thoroughly mastered field practice should be given in pruning, spraying, etc.

The exercises are arranged in groups which naturally fall under a common head. It is not likely that the instructor can begin with the first exercise and continue uninterruptedly to the 


\section{LABORATORY MANUAL OF HORTICULTURE}

last; he will probably find it desirable to make the order in which the exercises are used conform to the work in hand. For instance, if the discussion is on buds and pruning, it will be advisable to turn to that section and work out those exercises. If the discussion is on seeds, then the laboratory exercises dealing with germination of seeds should be assigned, and so on through the book. Care should be taken, however, not to assign tasks based on preceding exercises that have not been already worked out or discussed.

The author wishes to express his appreciation to Professor Wendell Paddock of the Ohio State University, Professors R. A. Emerson and J. R. Cooper of the University of Nebraska, and others for valuable suggestions offered in connection with this work.

GEORGE W. HOOD 


\section{CONTENTS}

EXERCISES

I. Comparative study of seed-testers . . . . . . . . 2

II. Seed-testing . . . . . . . . . . . . . . 6

III. Seed vitality limited by age . . . . . . . . . . . 10

IV. Absorption of water by seeds . . . . . . . . . . . 12

V. Germination hastened by soaking seeds . . . . . . . . 16

VI. The effect of drought on germinating seeds . . . . . . 18

VII. Seeds treated with chemicals to hasten germination . . . 20

VIII. The effect of commercial-fertilizer solutions on seeds . . 24

IX. The action of fungicides on seeds . . . . . . . . . 26

X. A study of bulbs . . . . . . . . . . . . . . 28

XI. A study of corms . . . . . . . . . . . . . . 30

XII. A study of soft or green wood cuttings . . . . . . . . 32

XIII. A study of leaf cuttings . . . . . . . . . . . 36

XIV. A study of root cuttings . . . . . . . . . . . 38

XV. A study of hardwood, or dormant, cuttings . . . . . . 40

XVI. A study of one-eye, two-eye, three-eye, mallet, and heel cuttings . . . . . . . . . . . . . . 44

XVII-XVIII. A study of buds (Prunus sp.)

Plums

Prunus domestica . . . . . . . . . . . . 48

Prunus triflora . . . . . . . . . . . . . 50

Prunus americana . . . . . . . . . . . . 50

Prunus hortulana . . . . . . . . . . . . 52

Prunus munsoniana . . . . . . . . . . . 52

The cherry

Prunus avium (sweet cherry) . . . . . . . . 54

Prunus cerasus (sour cherry) . . . . . . . . 58

XIX. A study of buds (Amygdalus sp.)

The peach

Amygdalus persica . . . . . . . . . . . 60

North China race . . . . . . . . . 60

Persian race . . . . . . . . . . . 62

South China race . . . . . . . . . . 62

Spanish race . . . . . . . . . . . . 64

Amygdalus platycarpa . . . . . . . . . . 64

Peen-to race . . . . . . . . . . . . 64

XX. A study of buds - pomaceous fruits

The apple

Malus sylvestris . . . . . . . . . . . . . . 66

The pear

Pyrus communis and Pyrus sinensis . . . . . . . 68

The quince

Cydonia vulgaris . . . . . . . . . . 70

$[\mathrm{V}]$ 


\section{LABORATORY MANUAL OF HORTICULTURE}

XXI. A study of buds - vine fruits

The grape

Vitis labrusca . . . . . . . . . . . 72

Vitis vinifera . . . . . . . . . . . 74

Vitis labrusca $\times$ vinifera . . . . . . 74

XXII. Pruning . . . . . . . . . . . . 76

XXIII. The pruning of the apple . . . . . . . 80

XXIV. The pruning of the pear . . . . . . . . 82

$\mathrm{XXV}$. The pruning of the plum and the cherry . . . . 84

XXVI. The pruning of the peach . . . . . . . 86

XXVII. The pruning of the grape . . . . . . . 88

XXVIII. The pruning of the brambles . . . . . . 90

XXIX. The pruning of the bush fruits . . . . . . . 92

XXX. The study of shield and prong budding . . . . 94

XXXI. The study of plate budding and H-budding . . . . 98

XXXII. The study of flute budding, ring budding, and chip budding . . . . . . . . . . . 102

XXXIII. The study of grafting-waxes

Beeswax and resin waxes . . . . . . . 108

Alcoholic waxes . . . . . . . . . 110

Pitch wax . . . . . . . . . . 110

XXXIV. The study of splice, whip, and double-whip grafting 112

XXXV. The study of cleft grafting and bark grafting . . 118

XXXVI. The study of bridge grafting . . . . . . . . . 126

XXXVII. The study of side grafting. . . . . . . . . 128

XXXVIII. The study of veneer grafting . . . . . . 130

XXXIX. The study of Bordeaux mixture . . . . . . . 132

XL. The study of lime-sulphur . . . . . . . . . . 138

XLI. The study of self-boiled lime-sulphur . . . . . . 144

XLII. The study of ammoniacal solution of copper carbonate 146

XLIII. The study of Paris green and arsenate of lead . . 148

XLIV. The study of kerosene emulsion . . . . . . 152

XLV-LIV. A study of the apple . . . . . . . . . . 154

LV-LX. A study of the grape. . . . . . . . . . . 174

LXI-LXVI. A study of the peach . . . . . . . . . . 186

LXVII-LXXII. A study of the pear . . . . . . . . . . 198

LXXIII-LXXVIII. A study of the plum . . . . . . . . . . 210

GLOSSARY . . . . . . . . . . . . . 223

INDEX . . . . . . . . . . . . . . . 233 
LABORATORY MANUAL OF HORTICULTURE 


\section{EXERCISE I}

\section{COMPARATIVE STUDY OF SEED-TESTERS}

Material. Dinner plates, blotters, canton flannel, germinating cups, tile germinator, Geneva seed-tester, germinating chamber.

Seed-testers are used for the purpose of testing the vitality of seeds. They differ greatly, and their efficiency varies with the kind. Study carefully four kinds.

1. The dinner-plate germinator consists of two large-sized dinner plates, one turned over the other, between which are two or three blotters covered with two pieces of canton flannel. Make a drawing showing the two plates and the inside material. The drawings should be at least three inches in diameter. Describe fully. Label all parts and describe the materials of which it is made. What can you say about the efficiency of this tester?

2. Germinating cups are small earthen cups three inches in diameter or three inches square and one and one-half inches deep, covered with a lid of the same size and shape as the top of the cup, in which are a number of small holes. Make a drawing, natural size, of a germinating cup and lid. Label, and give the dimensions on the drawings. Describe how the seeds can be germinated in this vessel. The cups must be placed in a shallow pan of water. Discuss the purpose of this procedure.

3. The tile germinator is a large tile twelve inches wide by fifteen inches long and two inches deep, in which have been molded pockets of varying sizes from one inch to three inches in diameter. This tester is placed in a shallow pan of water the same as the germinating cups. Make a drawing of the top view and a cross section, showing the number, size, and the depth of pockets. What advantage, if any, has this tester over the previous one? Give the exact dimensions on your drawing. Make the drawing two by three inches. How does the moisture get to the seeds? Discuss fully how you would germinate seeds in this tester. A pane of glass is usually placed over the top of the tester. What is the purpose of the glass? Give your opinion as to the value derived from its use. 
COMPARATIVE STUDY OF SEED-TESTERS

STUDENT'S NOTES AND REPORT

[3] 


\section{LABORATORY MANUAL OF HORTICULTURE}

4. The Geneva seed-tester is a galvanized iron pan ten inches wide, fourteen inches long, and three and one-half inches deep, with a ledge three eighths of an inch wide along the sides. The seeds are held in folds of cloth suspended on rods which rest on this ledge. Describe how the water is carried to the seeds.

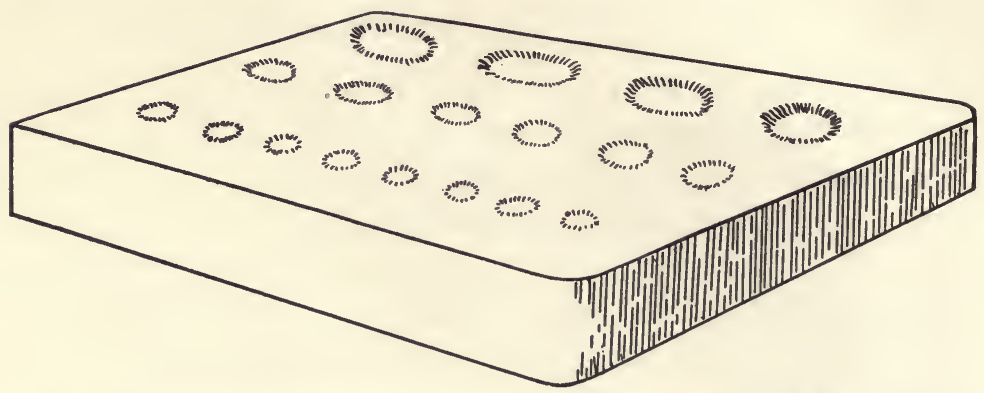

Fig. 1. Tile germinator, showing the different-sized holes in which the seeds are placed for testing

Make a drawing of the pan, three inches in length and of proportional width, showing the ledge. Draw an end view of the cloth. Give the depth of the pocket in inches, and measure the length of each end of the cloth from the supporting-rod. Why should the end pieces of the cloth be longer than the depth of the pocket?
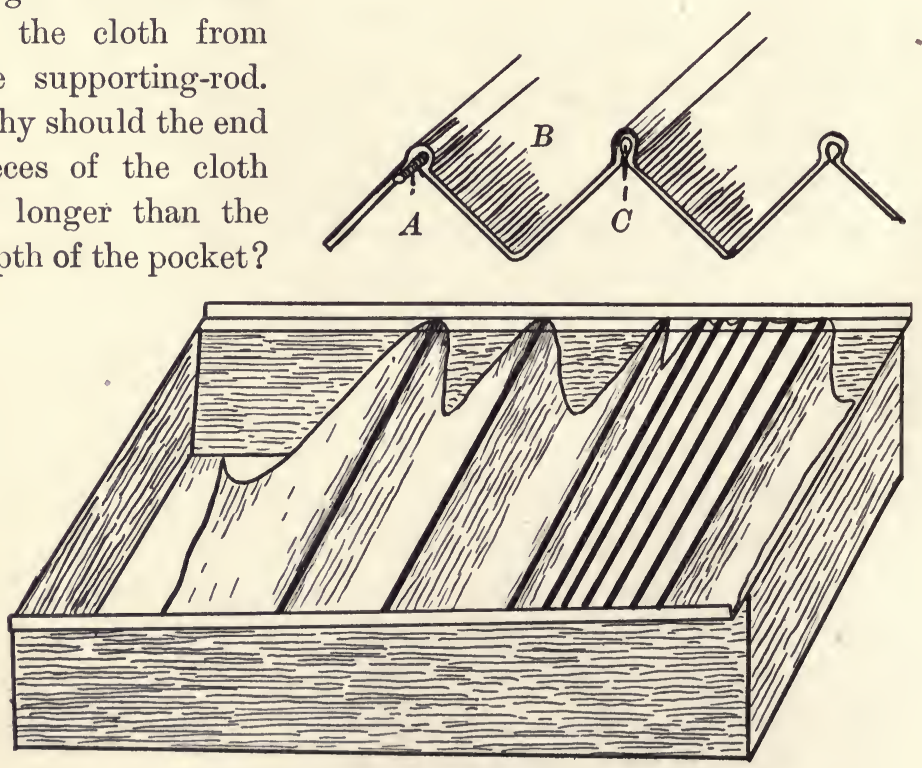

Fig. 2. Geneva seed-tester

$A$, supporting-rod for the cloth ; $B$, Canton flannel pocket ; $C$, opening through which the supporting-rod passes

[4] 
COMPARATIVE STUDY OF SEED-TESTERS

STUDENT'S NOTES AND REPORT 


\section{EXERCISE II}

\section{SEED-TESTING}

Material. Seeds of clover, celery, onion, cucumber, tomato, wheat, cabbage, oats, eggplant, beet, peas, rye, beans.

Apparatus. Sprouting-chamber, Geneva seed-tester, pane of glass the size of the tester.

Use the Geneva seed-tester to familiarize the student with this method, which can be applied on a large or a small scale. Each

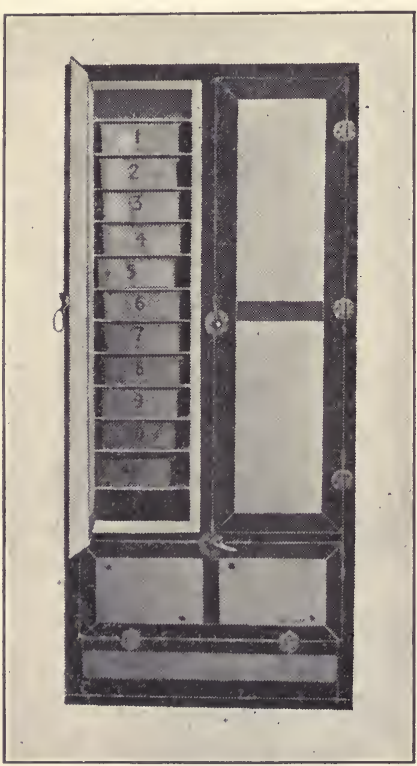

Fig. 3. Sprouting-chamber, or germinating-oven, showing the Geneva seed-testers on the shelves seed-tester should be thoroughly sterilized by placing about one inch of water in the pan, allowing the cloth to remain in the folds suspended on the rods, and boiling the water from fifteen minutes to a half hour, or until everything is thoroughly steamed. A piece of glass should be placed over the top of the tester to hold the steam and to give a more thorough sterilization.

1. Count out one hundred seeds of clover, celery, onion, cucumber, tomato, wheat, cabbage, oats, eggplant, beets, rye, and fifty seeds of peas and beans. Place the seeds in the tester, which has previously been thoroughly sterilized with steam. Discuss why we sterilize the tester. The tester should be placed in a sprouting-chamber where the temperature can be maintained around $80^{\circ} \mathrm{F}$. Why? Discuss fully what would happen to the seeds if the temperature were to fall as low as $50^{\circ} \mathrm{F}$. Why is it important that seeds should not be planted until the soil is thoroughly warmed up? Will any seed germinate in the presence of oxygen and moisture 
SEED-TESTING

STUDENT'S NOTES AND REPORT

Table of Results

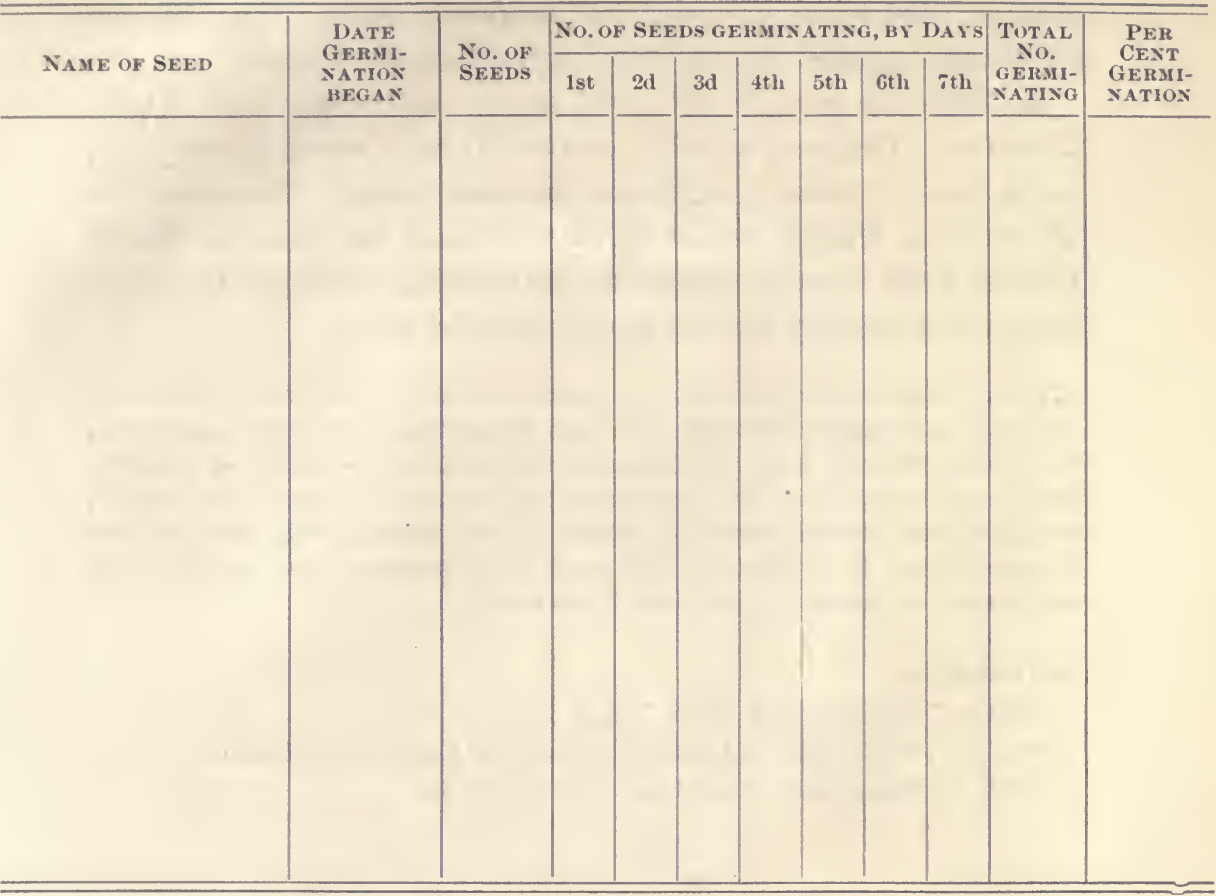




\section{LABORATORY MANUAL OF HORTICULTURE}

without heat? In testing seeds do all of them germinate at the same time? Discuss the irregularity of seeds in germinating when the same external conditions are given. Is a sproutingchamber necessary in order to germinate seeds? Discuss the advantages gained by the rapid germination of seeds.

2. Tabulate your results, and figure out the per cent of germination. This test should continue from a week to ten days, but a week is usually sufficient for most seeds. Remove all of the seeds as they germinate after the count has been tabulated. Discuss fully what is gained by seed-testing. Discuss the three essentials necessary for the germination of seeds.

Note. I have found that the most convenient size of the Geneva seed-tester for class use is eight inches wide, fourteen inches long, and three inches deep. No. 12 wire makes a good size to support the cloth, and the length of the cloth most convenient is four feet, containing ten pockets. In making the pockets, enough Canton flannel should be allowed for the making of the seam, so that the pocket may be at least one and one-half inches deep. Two or three such cloths may be placed in each pan if necessary.

\section{ReFERENCES :}

Bailey, "The Nursery Book," chap. i.

Bulletin No. 35, Rhode Island Agricultural Experiment Station.

Goff, "Principles of Plant Culture," pp. 24-32. 
SEED-TESTING

STUDENT'S NOTES AND REPORT 


\section{EXERCISE III}

\section{SEED VITALITY LIMITED BY AGE}

Material. Seeds of the cucumber, tomato, and cabbage, from one to ten years old.

Apparatus. Sprouting-chamber, Geneva seed-tester.

It is common knowledge that certain seeds lose their vitality with age. This varies with the variety of seed, the climate, the humidity, and other conditions.

1. Secure one hundred seeds each of the cucumber, tomato, and cabbage, one year old, two years old, three years old, four years old, five years old, six years old, seven years old, eight years old, nine years old, and ten years old, and place them in a Geneva seed-tester, the same as in Exercise II. Carry the germination test seven days and tabulate your results.

2. From your results, plot a curve showing the decrease in the vitality due to the age of the seed. At what age does the greatest vitality occur in each kind of seed? How do you account for this? Discuss the age limit of the different seeds.

TABle of Results

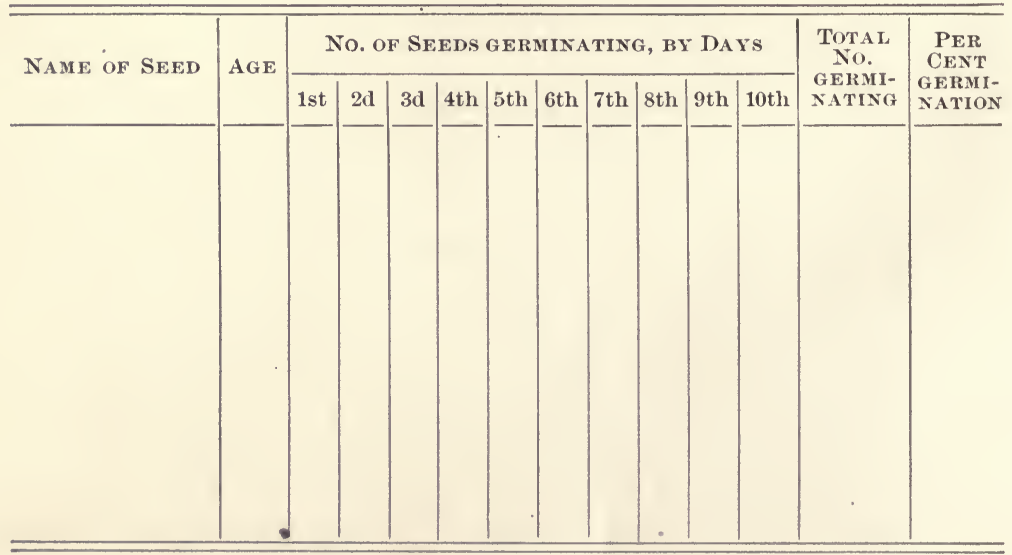

Note. Different-colored inks may be used to represent the different seeds ; for example, black $=$ cucumber, red $=$ tomato, green $=$ cabbage . 
SEED VITALITY LIMITED BY AGE

STUDENT'S NOTES AND REPORT

How to plot the CURVE

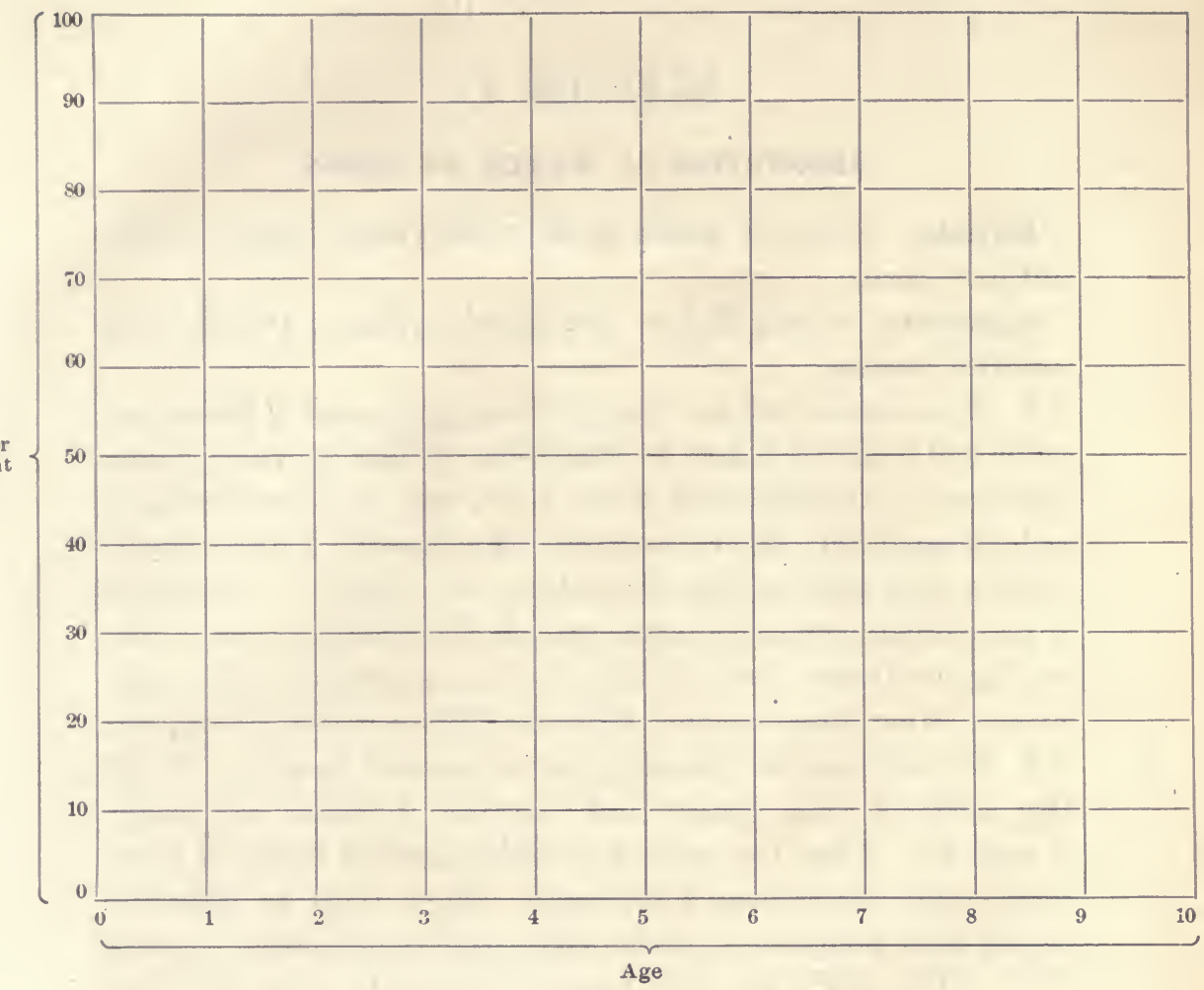




\section{EXERCISE IV}

\section{ABSORPTION OF WATER BY SEEDS}

Material. Seeds of beans, peas, corn, canna, honey locust, and field beans.

Apparatus. Scale, 250-cc. graduated cylinder, 100-cc. widemouthed bottles.

1. To determine volume. Partly fill the graduated cylinder with water and read the height to which the column of water stands. Now count out fifty seeds of the bean, pea, and corn and drop each lot separately into the water in the cylinder. Remove the air bubbles each time by slightly shaking the cylinder. The height of the column of water is again read and the difference in the two readings indicates the volume of each sample in cubic centimeters. How does this vary wth the different seeds? Explain.

2. To determine the amount of water absorbed by seeds. Weigh fifty seeds of peas, beans, and corn and tabulate the weight of each lot. Place the seeds in a wide-mouthed bottle of about $100 \mathrm{cc}$. and cover them with water. Allow them to stand for twenty-four hours in a room where the temperature is about $70^{\circ} \mathrm{F}$. The following day remove the seeds, wipe dry, and weigh. Tabulate your results. Discuss. Allow the same seeds to soak in water for another day and note whether there has been any increase in weight. At what time was the greatest amount of water taken up? Discuss.

3. Now take fifty more seeds, the same as in 2 , and treat in the same manner, only place them in a temperature of about $40^{\circ} \mathrm{F}$. Note your results and explain.

4. Secure fifty seeds of the canna or honey locust and treat them in the same manner as in 1 and 2. Note the difference, if any, and discuss. How do you account for the change?

5. Weigh out two samples of field beans and place one lot in water and the second sample in damp sand. Weigh each lot the two following days and compute the per cent of water absorbed by each. 
ABSORPTION OF WATER BY SEEDS

STUDENT'S NOTES AND REPORT 


\section{LABORATORY MANUAL OF HORTICULTURE}

6. Weigh out two samples of field beans and place one sample in loose, moist sand and the other in the same kind of sand, but well packed and pressed over the seed. Weigh the seeds the two following days. Discuss and give your reason for the results obtained.

REFERENCE :

Goff, "Principles of Plant Culture," pp. 22-25. 
ABSORPTION OF WATER BY SEEDS

STUDENT'S NOTES AND REPORT 


\section{EXERCISE V}

\section{GERMINATION HASTENED BY SOAKING SEEDS}

Material. Seeds of beans, peas, corn, lettuce, beet, cabbage, salsify, parsnip, carrot, wheat, and oats.

Apparatus. 100-cc. wide-mouthed bottles, Geneva seed-tester, sprouting-chamber.

1. Count out fifty seeds of beans, peas, and corn. Divide these into two lots of twenty-five seeds each and allow the first lot to soak for two hours. Treat the second lot in exactly the same way, but allow them to soak for twelve hours. Now place both sets in a Geneva seed-tester and allow them to germinate. What differences do you observe? How do you account for your results? Explain.

2. Count out one hundred seeds each of lettuce, beet, cabbage, salsify, parsnip, carrot, wheat, and oats and treat the same as in 1.

Now compare these results with those obtained in Exercise II, and plot a curve for beans, cabbage, and salsify, showing the difference, if any, in time of germination. Explain fully your results. What is gained by the soaking of seeds? Do all seeds respond alike? If not, why? 


\section{EXERCISE VI}

\section{THE EFFECT OF DROUGHT ON GERMINATING SEEDS}

Material. Seeds of clover, peas, beans, alfalfa, cowpeas, corn, wheat, rye, and oats.

Apparatus. Sprouting-chamber, Geneva seed-tester.

Germination is often interfered with by the drying out of the soil. The seeds of all dicotyledons suffer considerably from drying out, while the cereals and, in general, the seeds of all monocotyledons suffer but little. There are, however, a few exceptions, as corn, clover, beans, peas, etc.

1. Count out one hundred seeds each of clover, peas, beans, alfalfa, cowpeas, corn, wheat, rye, and oats. Place them in a Geneva seed-tester and allow them to germinate from twentyfour to forty-eight hours. Now remove the tester from the germinating-chamber, pour out the water, and spread the cloths out so that the seeds will dry for twenty-four hours, or until they are well dried, then pour water in the tester, and again wet the seeds thoroughly and place them in the germinating-chamber. Do this several times and note the results. At the same time carry on a check for each seed which has been treated in the normal way to compare with the others. What difference is seen in the germination? Do all the seeds respond alike? If not, why? What seeds are injured the most by drying out? What ones are not injured? Study carefully each sample and determine why some seeds are injured and some are not. Has the construction of the seed anything to do with the drying out? Tabulate and discuss your results fully. 
THE EFFECT OF DROUGHT ON GERMINATING SEEDS

\section{STUDENT'S NOTES AND REPORT}

TABLE of Results

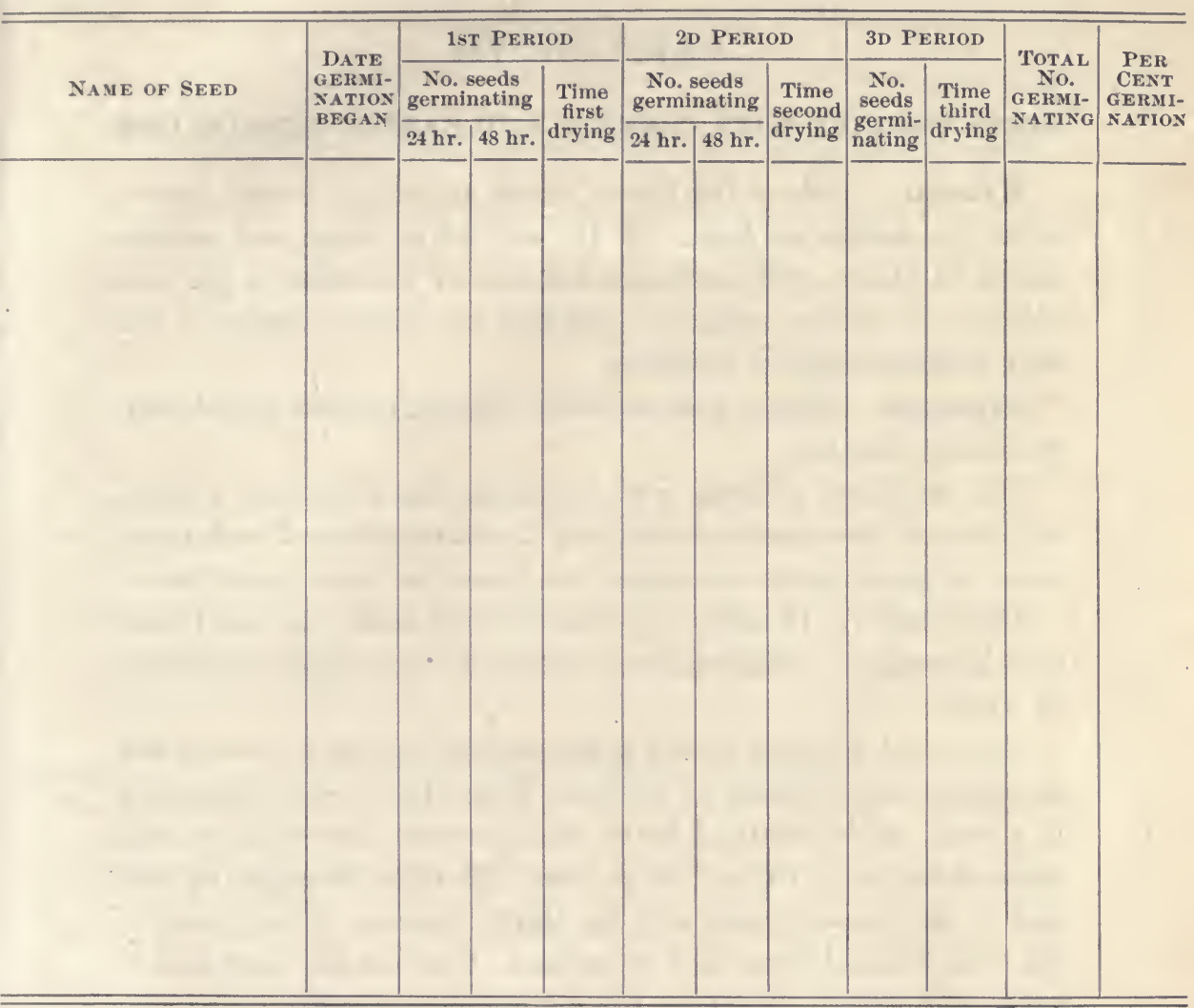




\section{EXERCISE VII}

\section{SEEDS TREATED WITH CHEMICALS TO HASTEN GERMINATION}

Material. Seeds of the honey locust, asparagus, wheat, barley, oats, rye, radish, cabbage. 5, 10, and 50 per cent and concentrated sulphuric acid, saturated solution of limewater, 2 per cent solution of iodine, saturated solution of chlorine water, 1 per cent monobromide of camphor.

Apparatus. 100-cc. wide-mouthed bottles, Geneva seed-tester, sprouting-chamber.

The treatment of seeds with chemicals has long been known, but definite information concerning the exact effect of such treatment on germination is meager and based on three hypotheses.

Hypothesis 1. If seeds are treated with acids, the hard seed coat is loosened, which makes possible the more rapid imbibition of water.

Count out five lots of ten seeds each of the honey locust and asparagus and proceed as follows: Place the seeds of each lot in a small, wide-mouthed bottle and immerse four of them each respectively in 5, 10, and 50 per cent dilutions of sulphuric acid and in the concentrated acid for thirty minutes. Place them in the Geneva seed-tester and germinate. Use one lot untreated to serve as a check. Tabulate the results every twenty-four hours on both treated and untreated seeds. Describe what action the acid of different strengths has on the seeds. What per cent of acid gives the best result? What per cent solution would you advise? Are both kinds of seed acted upon alike by the same solution? Plot a curve showing the increase in the time of germination over the nontreated seed. Use colored inks to show the difference in the time.

Hypothesis 2. If the evolution of carbonic acid gas can be hastened by the use of chemicals, germination will be facilitated.

Count out ten lots of one hundred seeds each of wheat, barley, oats, and rye. Place one lot of each seed in a 100-cc. widemouthed bottle, cover the seeds with a saturated solution of limewater, and allow them to remain immersed for thirty minutes. 


\section{LABORATORY MANUAL OF HORTICULTURE}

Now place the seeds in a Geneva seed-tester and germinate. The second lot of seeds should be germinated untreated in the same tester, under the same conditions, to serve as a check. Tabulate your results and describe fully what takes place. Plot a curve to show the increase in germination of seed that has been treated over seed that has not been treated.

Hypothesis 3. If you can set oxygen free, to unite with the carbon of the seed and thus form carbonic acid gas, which must pass off, germination will be hastened.

a. Count out one hundred seeds each of the radish, cabbage, and onion, and place each in a wide-mouthed bottle. Now cover them with a 60 per cent alcoholic solution of iodine (approximately 1.1 per cent solution) and allow the seed to soak or be kept moist with the solution until germination begins. Note the time of sprouting. Tabulate your results to show the increase in time. Discuss.

b. Count out four lots of one hundred seeds each of the radish. Place each lot in a bottle and keep the first moist with pure water, the second. with a 60 per cent alcoholic solution of iodine, the third with a saturated solution of chlorine water (approximately 1.8 per cent), and the fourth with a 1 per cent solution of monobromide of camphor. Describe fully what takes place and tabulate your results. Plot a curve to show what effect the different chemicals have on the germination of the radish seeds. 


\section{SEEDS TREATED WITH CHEMICALS TO HASTEN GERMINATION}

\section{STUDENT'S NOTES AND REPORT}

No. of seeds

\section{Curve to show Radisi Germination}

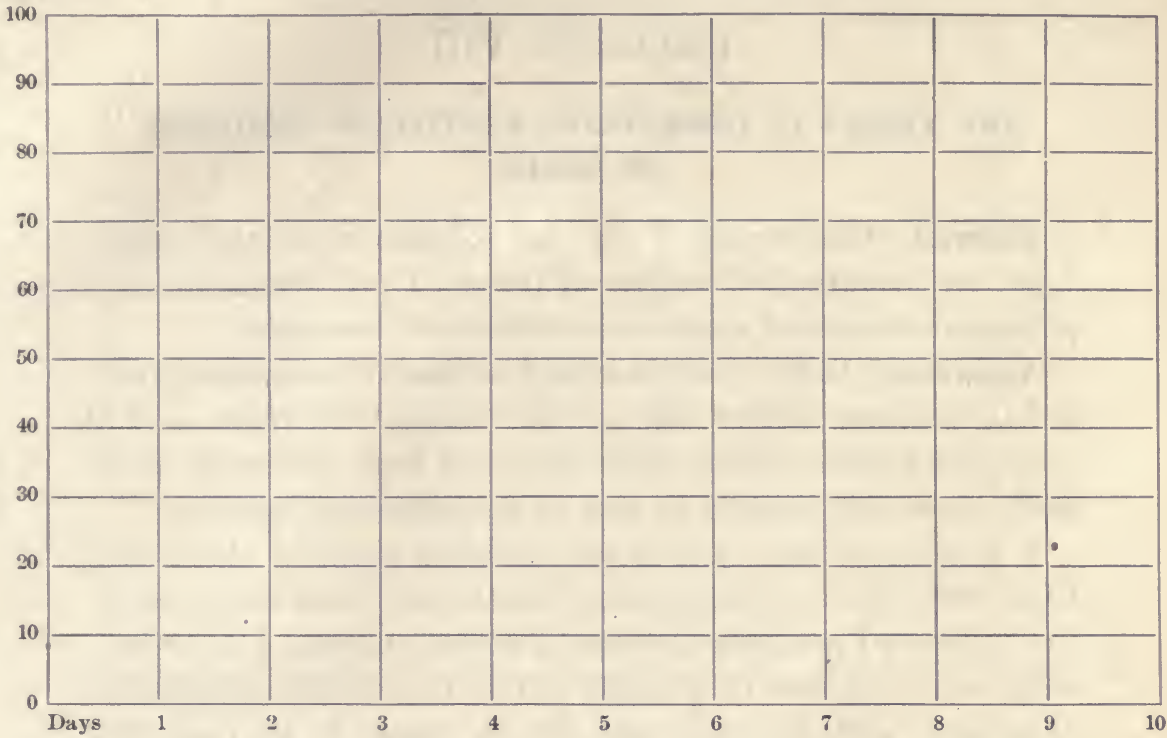

Noтє. Use different-colored inks or different symbols to represent the different solutions. 


\section{EXERCISE VIII}

\section{THE EFFECT OF COMMERCIAL-FERTILIZER SOLUTIONS ON SEEDS}

Material. Clover seed, 1 per cent solution of sodium nitrate, 1 per cent solution of muriate of potash, 1 per cent solution of phosphoric acid, and a saturated solution of limewater.

Apparatus. 100-cc. wide-mouthed bottles, Geneva seed-testers. It has long been known that certain chemical fertilizers, as well as certain forms of other chemicals, have some influence on the seed, in the soil solution as well as in an aqueous solution.

-1. Count out four lots of one hundred seeds of the clover. Place each lot in a wide-mouthed bottle and cover them respectively with a 1 per cent solution of sodium nitrate, a 1 per cent solution of muriate of potash, and a 1 per cent solution of phosphoric acid, allowing each lot to remain in its respective solution for twenty-four hours. Remove each sample, and germinate in the Geneva seed-tester. Place the fourth batch untreated in the seed-tester to serve as a check. Tabulate and diseuss your results in each case. Plot a curve showing the per cent of germination with each of the fertilizers and also when no fertilizer is used. Does it pay to allow a commercial fertilizer to come in direct contact with the seed? Discuss.

2. Mix in equal proportions a saturated solution of limewater with a 1 per cent solution of each of the following: sodium nitrate, muriate of potash, and phosphoric acid. Now with each solution treat such a batch of seeds as in 1, and germinate. Does the addition of the limewater to the seed aid in preventing any detrimental effect of the commercial fertilizers?

Do the fertilizers all act alike on the different seeds? Which fertilizer shows the most injurious effect? Are the seeds hastened or retarded in germinating by the use of fertilizers? Discuss. Tabulate your results, and plot a curve showing what effect the limewater has when added to each of the fertilizers. 
THE EFFECT OF COMMERCIAL-FERTILIZER SOLUTIONS

\section{STUDENT'S NOTES AND REPORT}

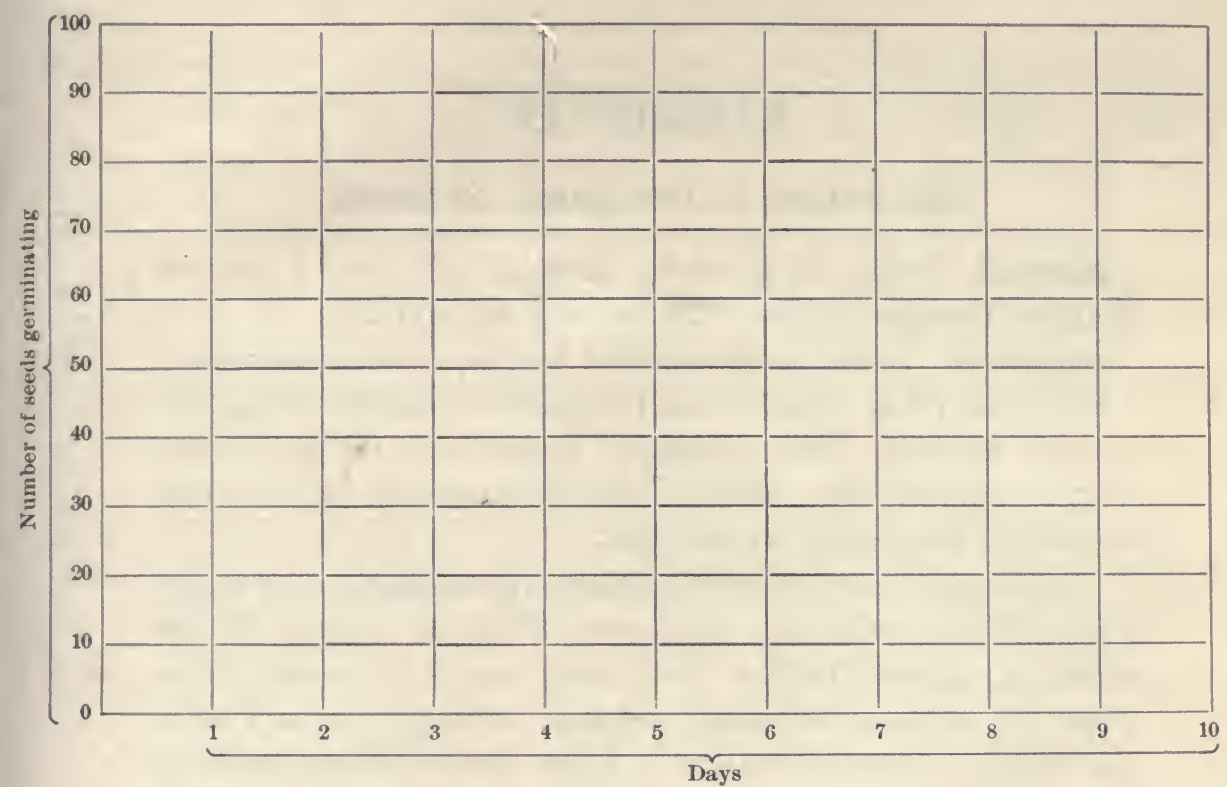

Note. Use different-colored inks or different symbols to illustrate each fertilizer.

\section{RECORD}

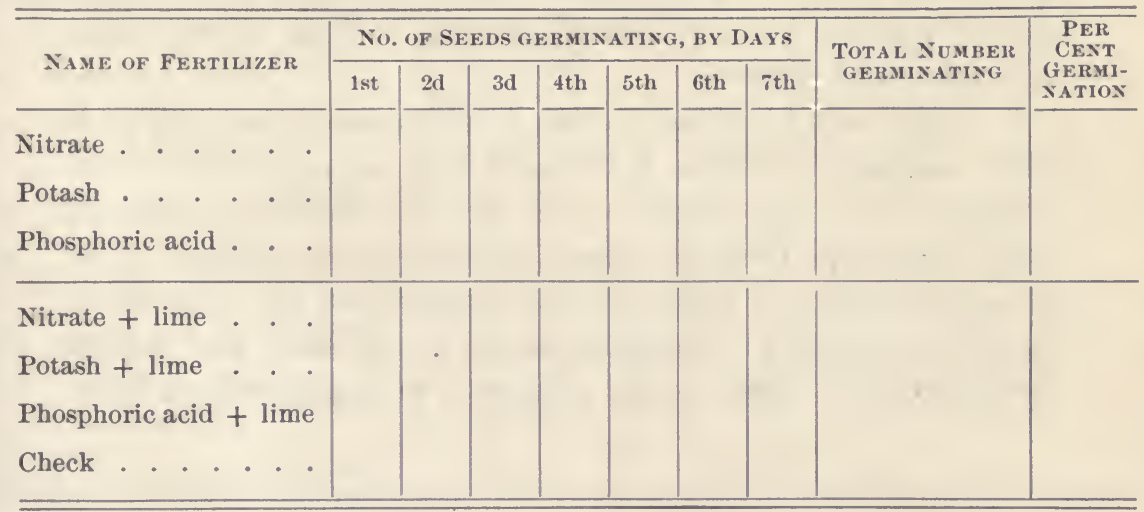




\section{EXERCISE IX}

\section{THE ACTION OF FUNGICIDES ON SEEDS}

Material. Seeds of the wheat, cabbage, and corn, 1 per cent solution of copper sulphate, 25 per cent salt solution.

Apparatus. 100-cc. wide-mouthed bottles, Geneva seed-tester.

Seeds are often treated with fungicides to destroy the spores of some diseases. This treatment, however, is dangerous and must be applied with extreme care and precision, in order that no damage may result to the seed.

1. Count out two lots, of one hundred seeds each, of the wheat, of the cabbage, and of the sweet corn. Place the samples of each variety in separate bottles. Now cover one lot of seeds with a 1 per cent solution of copper sulphate. Place the second lot in pure water to serve as a check. Allow both batches to soak for two hours, and then germinate. Tabulate your results, and explain. What strength of solution would you recommend for the treatment of seeds in order to insure the best results? Compare the treated seeds with the check. What is gained by the treatment? Did you note any fungus growing? What seeds, if any, were affected? Discuss.

2. Count out four lots of one hundred seeds each, as in 1 . Place each lot in a 100-cc. bottle, and keep one as a check. Pour enough of the salt solution over the first batch to cover the seeds, and allow them to remain immersed one minute. Soak the second batch of seeds for five minutes and the third batch for fifteen minutes. Germinate as in 1 , and note the results. Describe fully. Tabulate the results as in 1, and discuss fully. 


\section{THE ACTION OF FUNGICIDES ON SEEDS}

\section{STUDENT'S NOTES AND REPORT}

\section{Copplir Sulphate Solution}

\begin{tabular}{|c|c|c|c|c|c|c|c|c|c|c|c|c|c|c|c|c|c|c|}
\hline & \multirow{2}{*}{\multicolumn{3}{|c|}{ Nasie }} & \multirow{2}{*}{\multicolumn{3}{|c|}{ OF SEed }} & & & & \multicolumn{7}{|c|}{ No. of Seeds germisatixg, by Days } & \multirow{2}{*}{$\begin{array}{c}\text { TOTAL } \\
\text { NUMBER } \\
\text { GERMI- } \\
\text { NATIXG }\end{array}$} & \multirow{2}{*}{$\begin{array}{l}\text { PER Cent } \\
\text { GERMiNATION }\end{array}$} \\
\hline & & & & & & & & & & 1st & $2 d$ & $3 \mathbf{d}$ & 4 th & 5th & 6th & 7th & & \\
\hline Wheat & . & - & $\therefore$ & • & - & • & • & • & - & & & & & & & & & \\
\hline Cabba & & . & - & . & - & . & - & • & - & & & & & & & & - & \\
\hline Corn & . & - & . & . & - & - & - & • & - & & & & & & - & & & \\
\hline
\end{tabular}

\section{Salt Solution}

\begin{tabular}{|c|c|c|c|c|c|c|c|c|c|c|c|c|c|}
\hline \multirow{2}{*}{ NAME } & \multirow{2}{*}{ OF } & \multirow{2}{*}{ SEED } & & \multirow{2}{*}{$\begin{array}{l}\text { LENGTH } \\
\text { OF TIME } \\
\text { IMMERSED }\end{array}$} & \multicolumn{7}{|c|}{ No. of SEeds Germinatixg, by Days } & \multirow{2}{*}{$\begin{array}{c}\text { TOTAL } \\
\text { NUMBER } \\
\text { GERMI- } \\
\text { NATING } \\
\end{array}$} & \multirow{2}{*}{$\begin{array}{l}\text { PER CeNt } \\
\text { GERMINATION }\end{array}$} \\
\hline & & & & & 1st & $2 d$ & $3 d$ & 4 th & 5th & 6th & 7 th & & \\
\hline \multirow[t]{4}{*}{ Wheat. } & - & $\cdot$ & - & $1 \mathrm{~min}$. & & & & & & & & & \\
\hline & & & & $5 \mathrm{~min}$. & & & & & & & & & . \\
\hline & & & & $15 \mathrm{~min}$. & & & & & & & & & 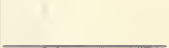 \\
\hline & & & & Check & & & & & & & & & \\
\hline \multirow[t]{4}{*}{ Cabbage } & - & .. & - & $1 \mathrm{~min}$. & & & & & & & & & \\
\hline & & & & $5 \mathrm{~min}$. & & & & & & & & & \\
\hline & & & & $15 \mathrm{~min}$. & & & & & & & & & \\
\hline & & & & Check & & & & & & & & & $\cdot$ \\
\hline \multirow[t]{4}{*}{ Corn } & . & .. & ${ }^{\circ}$ & $1 \mathrm{~min}$. & & & & & & & & & \\
\hline & & & & $5 \mathrm{~min}$. & & & & & & & & & 1 \\
\hline & & & & $15 \mathrm{~min}$. & & & & & $\cdot$ & & & & \\
\hline & & & & Check & & & & & & & & & 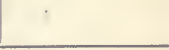 \\
\hline
\end{tabular}

\section{ReFERENCE :}

Bulletin No. 10, United States Department of Agriculture, Division of Vegetable Physiology and Pathology. 


\section{EXERCISE X}

\section{A STUDY OF BULBS}

Material and apparatus. Bulbs of the hyacinth, tulip, onion, and lily; sharp knife.

Bulbs of all kinds are specialized buds. They are made up of a short and rudimentary axis closely incased in transformed

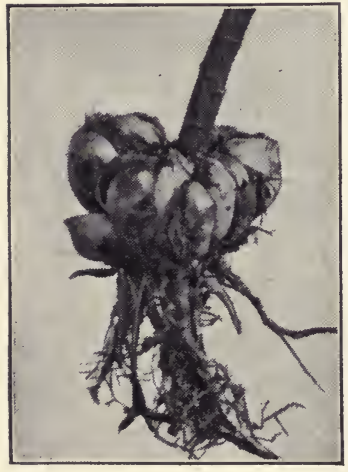

FIG. 4. Bulb of Easter lily and thickened leaves called bulb scales. Bulbs occur only in plants which are accustomed to long periods of inactivity, and are divided into two classes determined by the scales.

1. Study bulbs of the hyacinth, onion, tulip, and tiger lily or Easter lily. Make a drawing of each one, natural size, showing the external characteristics. Describe fully the differences in each bulb. How does the lily differ from the hyacinth?

2. Keep a close watch for bulbils, which are little bulbs found on the parent bulb. Where do you find these located? Are they in essentially the same place in each bulb? Make a drawing of the bulbil, natural size, showing the attachment to the parent.

3. Draw a cross section, natural size, of each bulb. What differences do you observe? Carefully examine and describe the bulb scales of the hyacinth and the tulip. How does the scale of the lily differ from that of the tulip and the hyacinth?

4. Draw a cross section of each scale. Describe in detail the differences. Measure the thickness of each bulb scale. What significance does the thickness of the bulb scale have? What is contained in the scales of all bulbs? How do the scales of the lily differ in arrangement and shape from those of the hyacinth and the tulip?

REFERENCE :

Bailey, "The Nursery Book," chap. ii. 


\section{BULBS}

STUDENT'S NOTES AND REPORT

[29] 


\section{EXERCISE XI}

\section{A STUDY OF CORMS}

Material and apparatus. Corms of the gladiolus and the crocus; sharp knife.

A corm is a bulblike organ, differing from a bulb in being solid throughout and not composed of fleshy scales. Cormous plants are multiplied in essentially the same way as are bulbous plants.

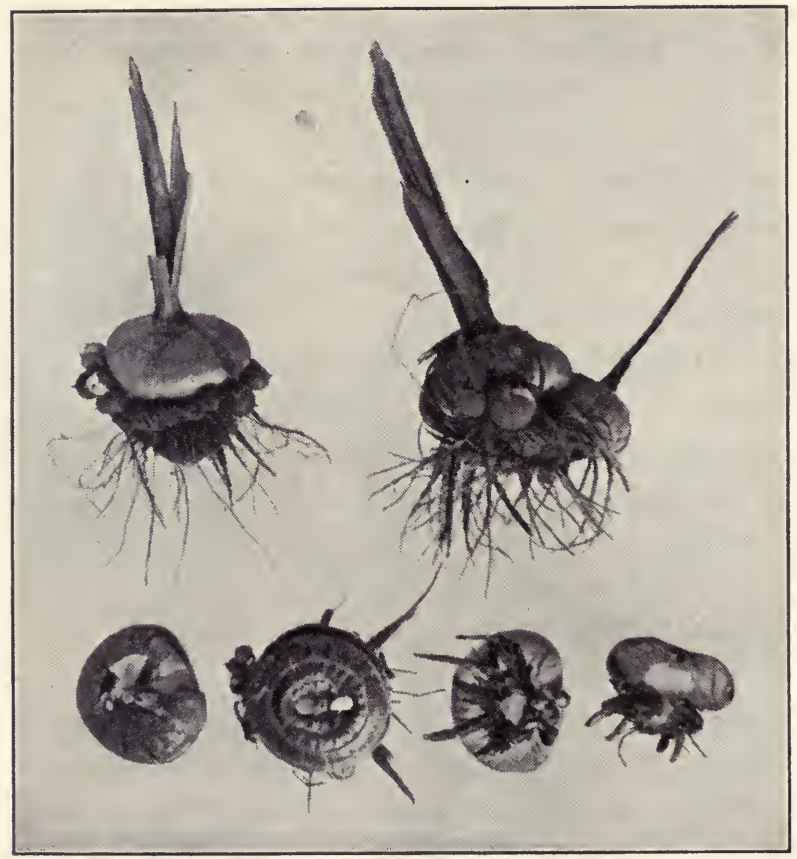

FIG. 5. Corms of the gladiolus, showing the cormels, or the little corms, about the parent

1. Study the corm of the gladiolus and the crocus. Make a natural-size drawing of each of the corms. What external differences do you note? Remove the outer husk and note the lines surrounding the corm. Discuss how a corm grows.

2. Draw a cross section, natural size, of both of the corms. How do they differ from the bulbs in Exercise $\mathrm{X}$ ? Is the shape of the corm the same as that of the bulb? Look for the central axis. Is this differentiated from the main body of the corm? Carefully examine the corm for eyes. Discuss fully. 
THE STUDY OF CORMS

STUDENT'S NOTES AND REPORT

[ 31 ] 


\section{EXERCISE XII}

\section{A STUDY OF SOFT OR GREEN WOOD CUTTINGS}

Material. Stock plants of the geranium, coleus, chrysanthemum, carnation, cactus, oleander, hydrangea, and rose, and rooted cuttings of each.

Soft or green wood cuttings are more commonly employed than those from mature wood because they root more quickly and can

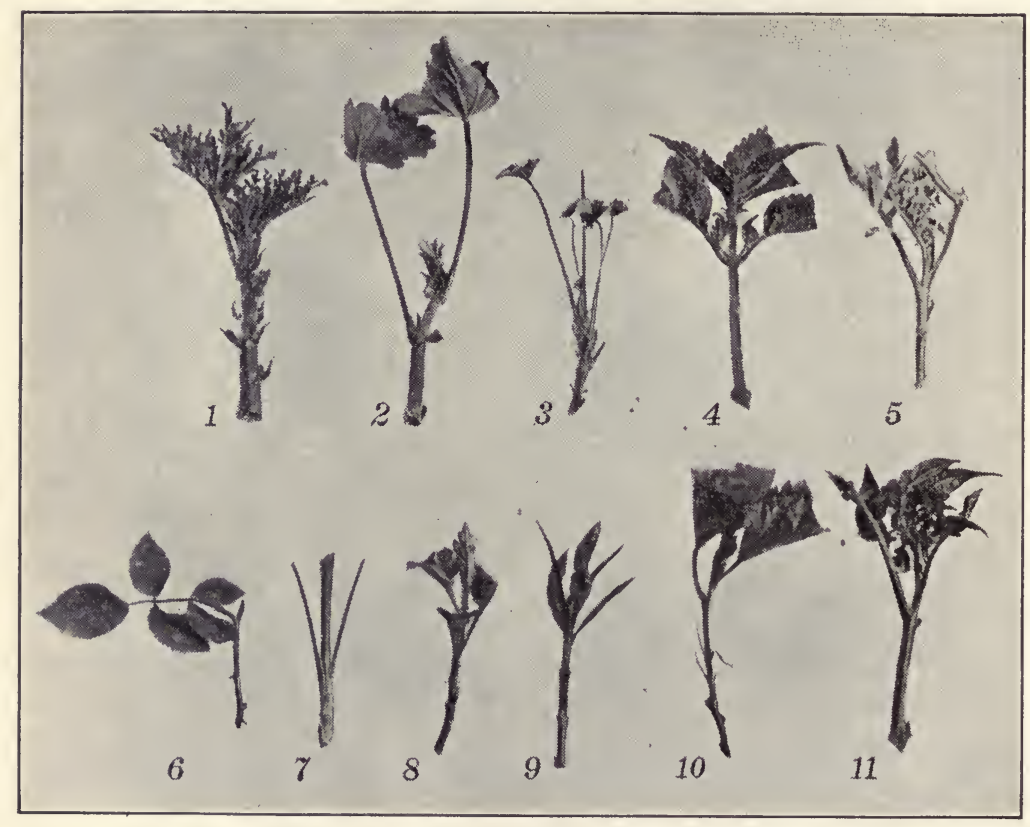

Fig. 6. Soft wood cuttings of different plants

1 , rose geranium ; 2 , geranium ; 3 , variegated geranium ; 4,5 , coleus ; 6 , rose ;

7 , carnation; 8 , chrysanthemum ; 9 , oleander ; 10 , hibiscus ; 11 , tomato

be handled under glass in winter, and also because more species are capable of propagation by this method. All soft-wooded and many ornamental plants are propagated by green wood cuttings.

There are two general classes of green wood cuttings: first, those that are made from the soft and still-growing wood, and second, those that are made from the green but nearly ripened wood. 
SOFT OR GREEN WOOD CUTTINGS

STUDENT'S NOTES AND REPORT 


\section{LABORATORY MANUAL OF HORTICULTURE}

1. Select several plants, such as the geranium, coleus, carnation, chrysanthemum, cactus, etc., and study. Make a number of cuttings from each kind of plant. Draw a cutting, natural size, from each of the plants, and label. It is always best to remove about one half of the leaves before planting the cutting. Why is this procedure necessary? Explain. Now secure some cuttings from each of the above plants that have been rooted, and examine carefully. Where do the roots start? Is there any callus tissue present? If so, describe. Make a drawing showing the callus tissue, and the roots just starting. Label all of the parts.

2. Secure several plants with semihard wood, such as the oleander, rose, hydrangea, etc., and compare these plants with those in 1. What difference do you find in the texture of the wood? Describe any other unlikeness or differences. Make a natural-size drawing of each cutting, four inches in length. Differentiate between the still-growing and the nearly ripened wood cutting. 
SOFT OR GREEN WOOD CUTTINGS STUDENT'S NOTES AND REPORT 


\section{EXERCISE XIII}

\section{A STUDY OF LEAF CUTTINGS}

Material. Stock plants of the begonia, bryophyllum calycinum, and gloxinia, and rooted leaf cuttings of each.

Many plants having thick, fleshy leaves can easily be propagated by leaf cuttings. In some plants the entire leaf is used;

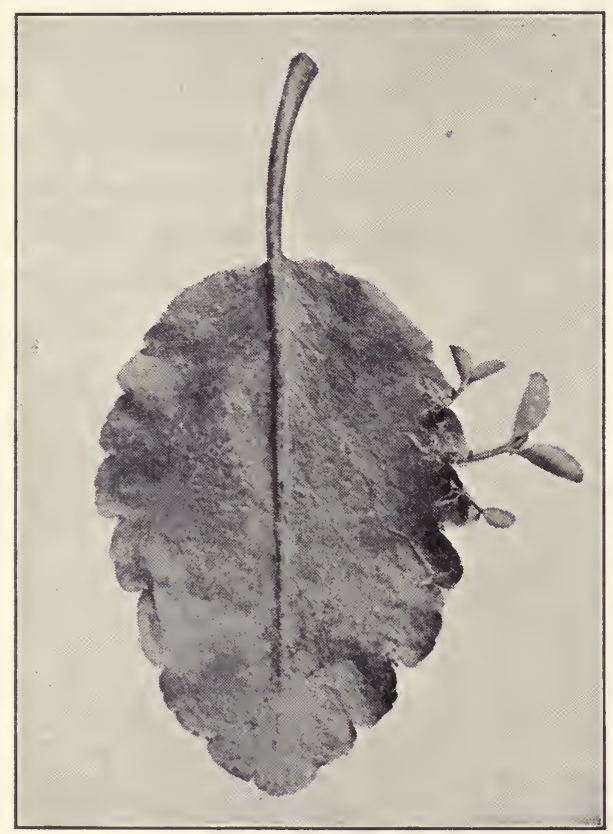

Fig. 7. Leaf of the bryophyllum, showing the starting of the young plants in others the leaf is cut half in two and placed in the ground on its edge. In some begonias the leaf is cut into several fan-shaped sections, each cutting having a portion of the petiole attached.

Study the begonia, bryophyllum, and gloxinia. Each plant represents a different form of leaf cutting.

1. Begonia. Draw a leaf of one of the large, thick-leaved types. Indicate by dotted lines where the cuts should be made to produce thefan-shaped cuttings. Draw a single cutting. How is it planted? Where does the young plant start? Discuss.

2. Bryophyllum. Draw a leaf natural size, and note the growing points. Describe. This plant is usually propagated by laying the leaf flat on the surface of the ground, where several small plants will start. Study a leaf from which the young plants have started. Where is the origin of each plant?

3. Gloxinia. Draw and describe a rooted leaf cutting. 
A STUDY OF LEAF CUTTINGS

STUDENT'S NOTES AND REPORT 


\section{EXERCISE XIV}

\section{A STUDY OF ROOT CUTTINGS}

Material. Blackberry and horse-radish roots and planted cuttings of each.

Many plants can be multiplied with ease by means of short cuttings of the roots. True root cuttings possess no buds at all,

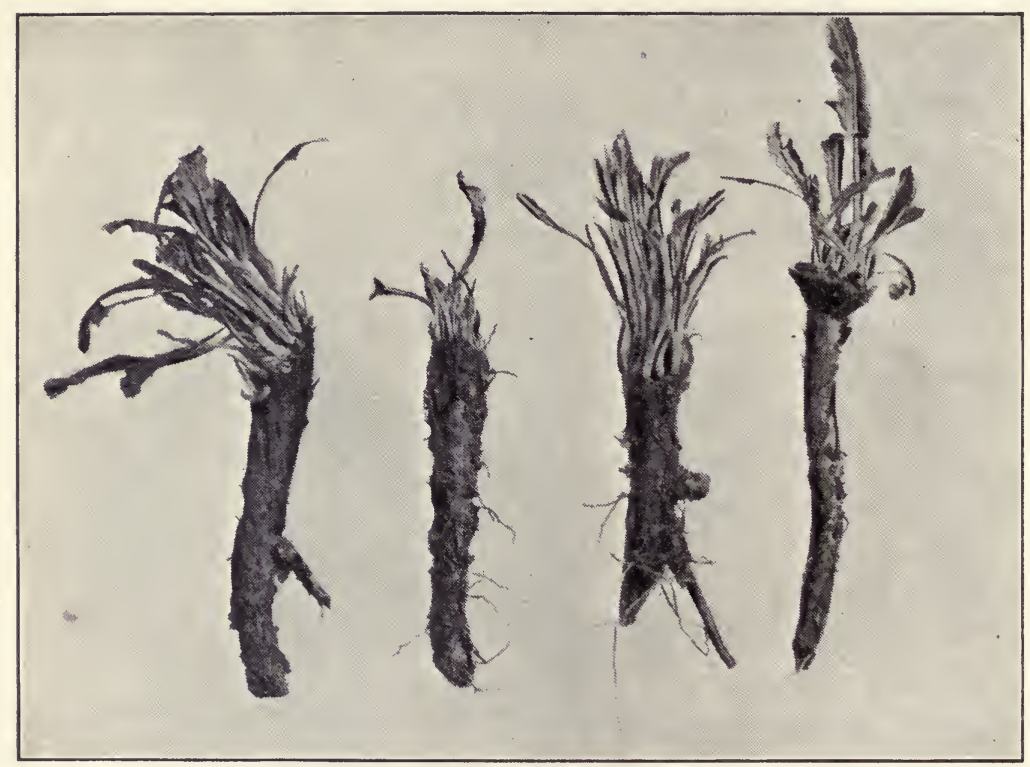

Fig. 8. Root cuttings of the horse-radish

but buds develop after the cutting is planted. The roots are cut into pieces from one inch to three inches in length and planted horizontally.

1. Secure roots of the blackberry and horse-radish, both of which are easily propagated by root cuttings. Practice making a number of these cuttings. Make a natural-size drawing of a root cutting from each of the plants. Look carefully for buds. Can any be found? Now secure cuttings of the above that have been planted for some little time. Examine these for buds. Where are the buds found? Make a drawing showing the bud, and differentiate between the two cuttings. Discuss. 
A STUDY OF ROOT CUTTINGS

STUDENT'S NOTES AND REPORT

[39 ] 


\section{EXERCISE XV}

\section{A STUDY OF HARDWOOD, OR DORMANT, CUTTINGS}

Material and apparatus. Currant and gooseberry branches and rooted cuttings of each; sharp knife.

Hardwood cuttings are made from the dormant, or mature, wood of dicotyledonous plants, and should be cut just below a node because they form roots more promptly if cut at this point. They are.usually taken in the fall or the early winter and stored in a cool place in sand so that they will callus over before being planted the following spring.

1. Study hardwood cuttings of the currant and the gooseberry. These cuttings should be about six inches in length, and, if the weather permits, the students should be allowed to collect their own cuttings from the parent bush.

Make a natural-size drawing of each of the cuttings. How many buds are usually found on each? How does the cutting of the currant differ from that of the gooseberry? What is the age of the wood from which cuttings are taken? Describe.

2. Study some cuttings of the currant and the gooseberry that have been stored in damp sand for two months. How do they differ from cuttings just taken? Make a drawing of the lower end of the cutting, showing the callus tissue. What is the purpose of this tissue? Label all parts, and discuss.

3. Study some cuttings that have just started into growth. From what position on the cuttings do the roots come? Explain. What indications are there on the cuttings that roots are forming? Discuss.

REFERENCES :

Bailey, "The Nursery Book," chap. iv.

Goff, "Principles of Plant Culture," pp. 207-218. 
A STUDY OF HARDWOOD, OR DORMANT, CUTTINGS

STUDENT'S NOTES AND REPORT 


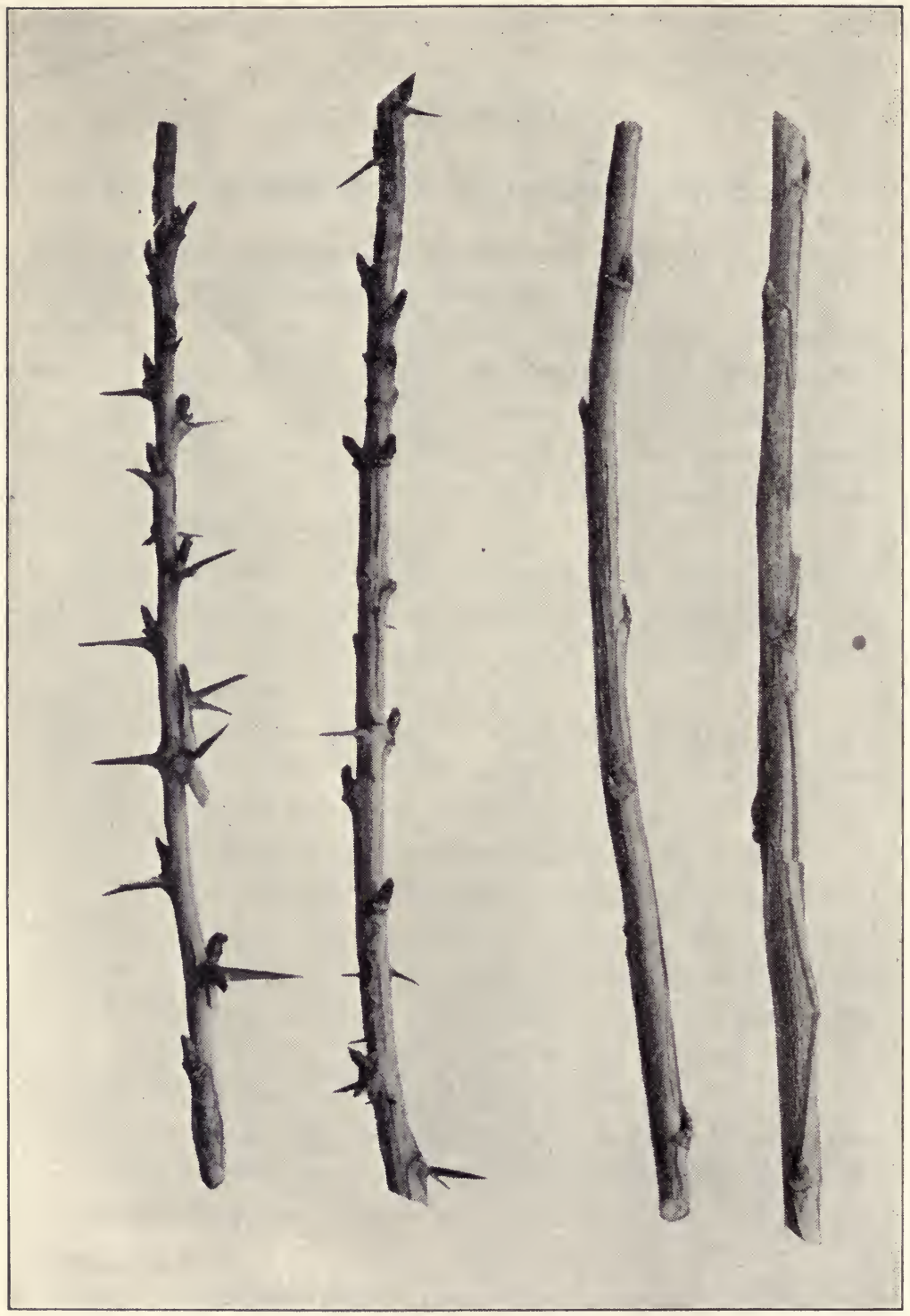

Fig. 9. Hardwood cuttings of the gooseberry and the currant Natural size 
A STUDY OF HARDWOOD, OR DORMANT, CUTTINGS STUDENT'S NOTES AND REPORT 


\section{EXERCISE XVI}

\section{A STUDY OF ONE-EYE, TWO-EYE, THREE-EYE, MALLET, AND HEEL CUTTINGS}

Material. Grape canes, stored and rooted cuttings of the grape. These cuttings fall under the general head of hardwood cuttings, but they represent different forms which are best suited

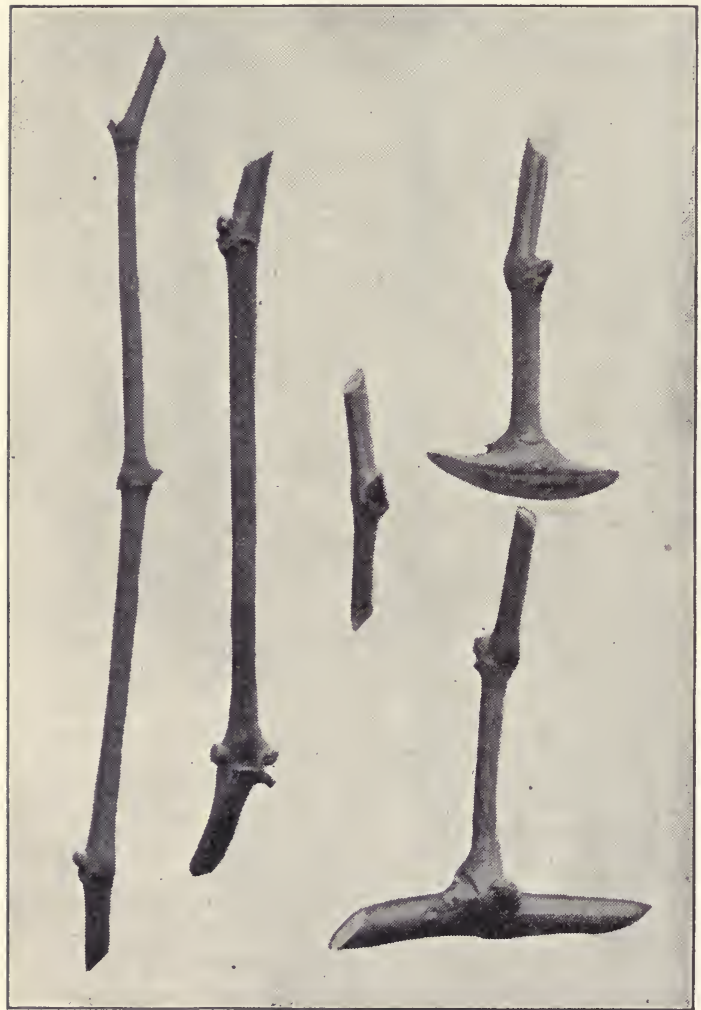

Fig. 10. Hardwood cuttings of the grape, showing the three-eye, the two-eye, the one-eye, the heel, and the mallet cutting to certain plants. The plant which lends itself best to the study of these forms of hardwood cuttings is the grape.

1. A one-eye cutting is a hardwood cutting containing one welldeveloped and mature bud, with a small piece of the branch on each side of the bud. These cuttings are laid flat when planted. Make a naturalsize drawing of a one-eye cutting of the grape. How long is this cutting? Label, and describe.

2. A two-eye and a three-eye cutting are cuttings containing two and three buds respectively, with a small portion of the branch at each end. Make a natural-size drawing of each cutting. How long are 
A STUDY OF MALLET AND HEEL CUTTINGS

STUDENT'S NOTES AND REPORT 


\section{LABORATORY MANUAL OF HORTICULTURE}

the internodes? Study from a stored cutting the callus tissue which has formed. Does this differ from the callus tissue in the currant and the gooseberry?

3. A mallet cutting is a cutting that contains a small section of the parent branch forming a $T$, or mallet, at its base (Fig. 10). Some varieties of grapes, as well as many ornamentals, root easily from this kind of a cutting. It should usually have two buds. Make a natural-size drawing showing the mallet. The mallet portion should be about one inch in length. Label all parts. These cuttings are treated in the same way as single-stem cuttings.

4. A heel cutting is a cutting with a small portion of the wood of the previous year at its base (Fig. 10). This is similar to the mallet cutting, but the heel is only a small piece shaved from one side of the parent branch.

Make a drawing showing the cutting attached to the parent branch, and indicate by dotted lines where the cut should be made. This cutting should contain two buds.

Compare this with the drawing made in 3 and give the significance of both forms. What advantages have mallet cuttings and heel cuttings over one-eye, two-eye, and three-eye cuttings? Discuss hardwood cuttings in general.

REFERENCE :

Farmers' Bulletin No. 15\%, pp. 10-12. 
A STUDY OF MALLET AND HEEI, CUTTINGS

STUDENT'S NOTES AND REPORT 


\section{EXERCISE XVII}

\section{A STUDY OF BUDS (Prunus sp.)}

Material and apparatus. Branches of several of the commercial groups of plums, bearing fruit buds and branch buds; razor,

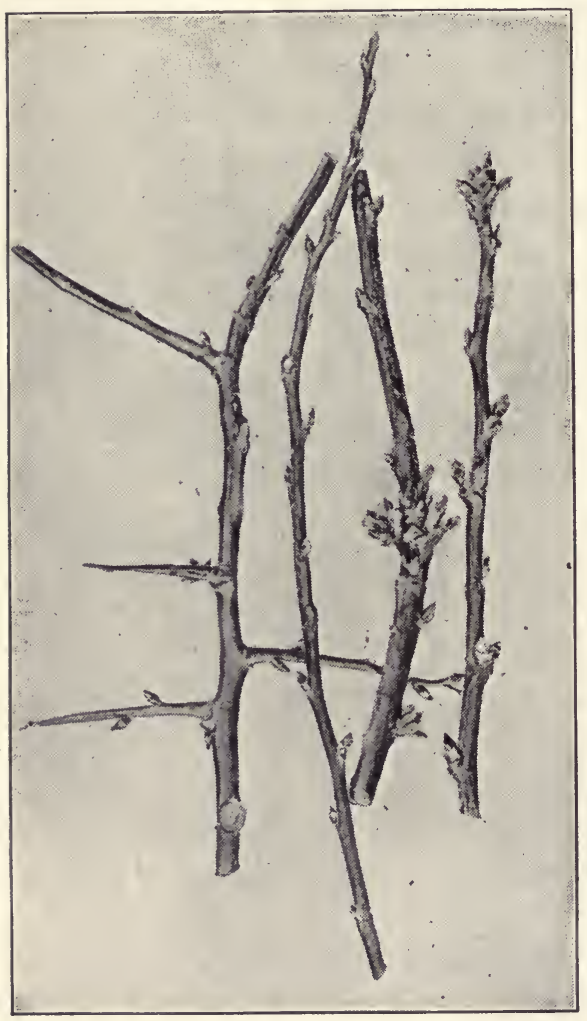

Fig. 11. Branch buds and fruit buds of plum Note the clusters of buds that are borne on the short spurs dissecting lens.

The genus Prunus includes the plum and the cherry, and is widely distributed. These species, cultivated for their edible fruit, are found only in the temperate zone of the northern hemisphere. The flowers, twigs, and buds in each group will be found to differ, as may be verified after studying them.

\section{Plums}

The plums are divided into several important, more or less distinct, commercial groups, with many hybrids between the groups. The following groups are a few that admit of careful study.

1. Prunus domestica includes the following varieties: Bavay, Lombard, Gold Drop, Arch Duke, Diamond, Monarch, Italian Prune, Yellow Gage, and several others.

a. Secure branches, including both fruit buds and branch buds, of one of the above varieties. Draw a twig, natural size, and at [48] 
A STUDY OF BUDS

STUDENT'S NOTES AND REPORT 


\section{LABORATORY MANUAL OF HORTICULTURE}

least four inches in length. Measure the distance between the internodes and count the number of buds in a cycle. Describe the color of the bark. Are the lenticels numerous or few? Describe.

b. Draw a longitudinal and a cross section of both a flower bud and a branch bud. Describe the differences. How many ovules do you find in a bud? Is the number constant or variable? Discuss. Does the fruit bud differ from the branch bud in position on the stem? Discuss.

c. Make a drawing, at least one inch in length, of a branch bud and a flower bud. Remove several of the bud scales, and make a drawing of a scale from both the branch bud and the flower bud. Are there any differences? If so, describe.

2. Prunus triflora includes the following varieties: Ogon, Occident, Red June, Willard, Abundance, and several others.

$a$. Secure branches from one or more of the varieties named or others of the Prunus triflora that are available. Make a natural-size drawing of a branch four inches. in length, showing the number and the position of the buds. Count from external appearance the number of fruit buds and branch buds. Measure the distance between the buds, and count the number in a cycle. Is the number constant? Discuss.

$b$. Make a drawing of a longitudinal and a cross section of both a branch bud and a flower bud. This drawing should show detail and be at least one inch in length. How many ovules do you find in the flower bud. Label all parts. Describe.

c. After a branch bud and a flower bud have been definitely determined, make a drawing showing each bud enlarged to one inch. What internal and external differences do you note? How can you distinguish the flower bud from the branch bud by external appearance?

$d$. Describe fully the difference between these buds and those of the Prunus domestica and the Prunus triflora in gross appearance, in size, in location and arrangement, and in any other points noted by you.

3. Prunus americana includes the following varieties: Hawkeye, De Soto, Weaver, Wood, Wyant, and some others.

$a$. Secure branches from one of the above varieties, including both fruit buds and branch buds, and make a drawing, natural size, and four inches in length. Note the color of the bark and 


\section{A STUDY OF BUDS}

STUDENT'S NOTES AND REPORT 


\section{LABORATORY MANUAL OF HORTICULTURE}

the number of the lenticels. How does the Prunus americana differ from the Prunus domestica and the Prunus triflora in these respects? Describe fully.

b. Make a drawing, at least one inch in length, of both the branch bud and the flower bud. Are the buds arranged on the stem singly, or in clusters at the apex of a spur? Count the buds in each cluster, and note whether the number is constant or variable. Describe a fruit spur, and note how it grows. What is the direction of the growth? Why is this? Where do you find the branch bud? Has the position of the branch bud anything to do with the direction of the growth in the spur?

4. Prunus hortulana includes the following varieties: Moreman, Wayland, World Beater, Golden Beauty, and several others.

$a$. Secure branches from one of the above varieties, including both fruit buds and branch buds. Make a drawing, four inches in length, and natural size, to show a twig which has both kinds of buds. Describe the color of the bark and the general appearance of the lenticels. Note any differences from the preceding groups.

$b$. Make an enlarged drawing of a fruit bud and a branch bud. Describe how the buds are arranged. Are they larger or smaller than those of the preceding groups? Discuss.

5. Prunus munsoniana includes the following varieties: Poole Pride, Pottawattamie, Newman, Robinson, Sophie, Wild Goose.

a. Make a drawing, natural size, and four inches in length, of a twig, including flower buds and branch buds. How do these buds differ from those of the preceding groups? Describe the buds, the lenticels, and the color of the bark.

b. Make an enlarged drawing, one inch in length, of a branch bud and a flower bud. Draw a separate scale of each. How do the scales differ? Are the buds arranged singly or in groups?

Comparative study of the plums. Describe in detail the points of difference between the branch buds and the flower buds in each group. Which are arranged singly, and which are in clusters? Count the ovules in at least ten different buds. Is the number constant? Describe any difference in the longitudinal and the cross sections of the buds in the different groups.

\section{REFERENCES :}

Bailey, "The Pruning Book," pp. 21-29, 46-50.

Goff, "Principles of Plant Culture," pp. 86-95.

Paddock and Whipple, "Fruit Growing in Arid Regions," pp. 66-80. 
A STUDY OF BUDS

STUDENT'S NOTES AND REPORT

[53] 


\section{EXERCISE XVIII}

\section{A STUDY OF BUDS (Prunus sp.)}

Material and apparatus. Branches of the sour and the sweet cherry, bearing both branch buds and fruit buds; razor, dissecting lens.

\section{The Cherry}

There are two large groups of cherries - Prunus cerasus and Prunus avium - which probably sprang from the European species. They differ in habit of growth, in shape, and in the arrangement of buds, as well as in other characteristics. The domestic forms of Prunus avium are characterized by a tall, erect growth, by reddish-brown bark, and by flowers generally in clusters on lateral spurs. The fruit is red, yellow, or black, and sweet. Prunus avium has four representatives in the United States - mazzards, hearts, bigarreaus, and dukes. Prunus cerasus is characterized by low-headed and spreading forms of trees, by flowers in clusters on lateral spurs, and by thin, willowy branches. There are two representatives in the United States - amarelles and morellos. For convenience all cherries are divided into the bigarreaus, or sweet cherries, and the morellos, or sour cherries. These are subdivided according to color and form of fruit, but the subdivisions are of minor importance for consideration at this time.

1. Bigarreau group. The bigarreaus, or sweet cherries (Prunus avium), include the following varieties: Black Eagle, Black Heart, Black Tartarian, American Heart, Cleveland, Coe's Transparent, Sweet Montmorency, Windsor, Bing, Lambert, Royal Ann, and many others.

a. Secure branches from one or more of the varieties named above, and study thoroughly. Make a drawing, natural size, and at least four inches in length, showing both the branch buds and the fruit buds. Where are they located, and how are they arranged? What external differences do you find between the fruit bud and the branch bud? What bud predominates, and 
A STUDY OF BUDS

STUDENT'S NOTES AND REPORT 


\section{LABORATORY MANUAL OF HORTICULTURE}

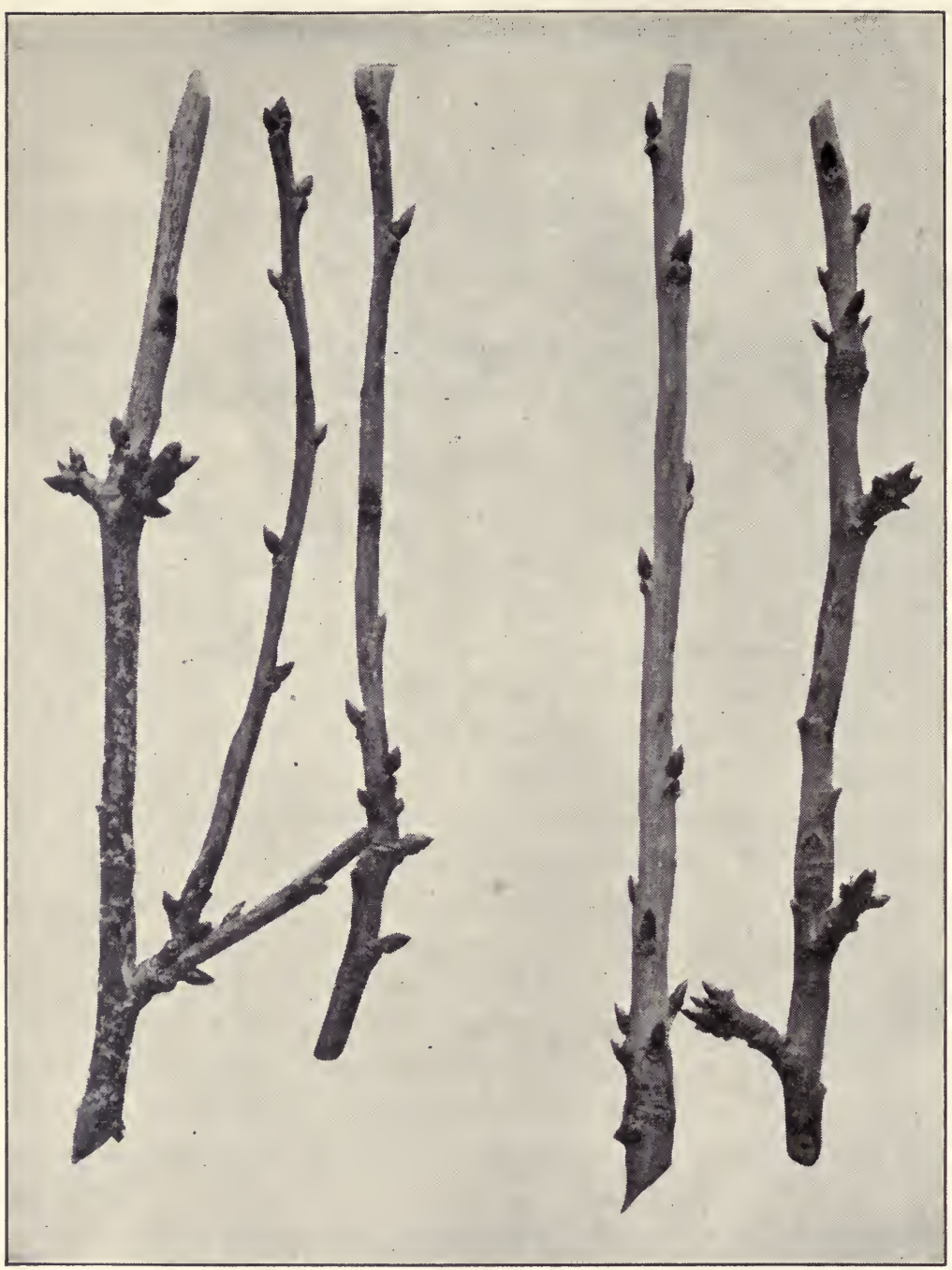

Fig. 12. Branches showing the branch buds and the flower buds of the sour and the sweet cherry

why? Does the position of the fruit bud differ from that of the branch bud? Is the relative position of the two kinds of buds always the same? Discuss.

b. Make a drawing, at least one inch in length, of a branch bud and a flower bud. Remove a scale from each bud, and draw. Are there any differences between the branch-bud scales and the fruit-bud scales? Describe. 
A STUDY OF BUDS

STUDENT'S NOTES AND REPORT 


\section{LABORATORY MANUAL OF HORTICULTURE}

c. Make a drawing of a longitudinal and a cross section of a branch bud and a fruit bud. Describe the internal differences. Make a dozen or more sections of the flower buds and count the ovules in each. Is the number constant? Can you give any reason for variation? Is there any ratio between the number of ovules in the buds and the number of clusters in the group? Do you find the buds arranged singly, or in groups on short spurs? Where do you find the greatest number of buds, and how old is the wood on which they are borne? Describe the relative position of the branch bud and the fruit bud.

2. Morello group. The morellos, or sour cherries (Prunus cerasus), include the following varieties: Early Richmond, May Duke, Montmorency, Morello, Royal Duke, Wragg, and several more.

a. Secure branches from one or two of the above-named varieties, or from any other of the sour cherries, and study carefully. Make a drawing of a branch, natural size, and at least four inches in length. Describe the differences between the branches of the sweet and the sour cherry.

b. Make a drawing, at least one inch in length, of a fruit bud and a branch bud. How do these buds differ from those of the sweet cherry? Are the buds arranged singly or in elusters? Do you find spurs on the sour cherries? Describe fully. Now cut cross sections of several fruit buds. How many ovules do you find? Is the number constant, and does it differ from the number in the sweet cherry?

$c$. Describe fully the differences between the buds of the sweet cherry and those of the sour cherry. Describe the general appearance of a branch of each. Which branch gives the impression of a rigid, stiff, and upright growth? Describe the difference in the bark of the two cherries. 
A STUDY OF BUDS

STUDENT'S NOTES AND REPORT 


\section{EXERCISE XIX}

\section{A STUDY OF BUDS (Amygdalus sp.)}

Material and apparatus. Branches of the several races of the peach, bearing fruit buds and branch buds; razor, dissecting lens.

\section{The Peach}

The peach is divided into five somewhat distinct races. The characteristics which separate each race are more or less pronounced. Each one includes a number of different varieties, some

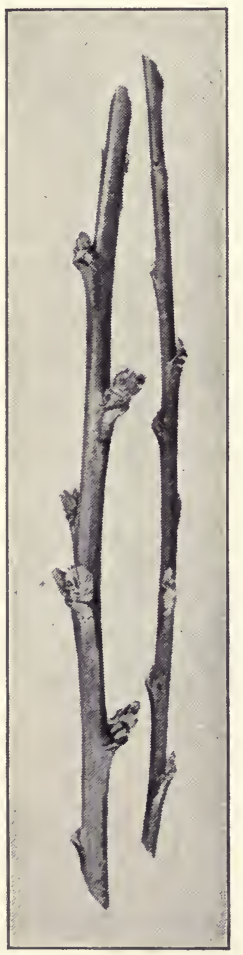

Fig. 13. Fruit buds and branch buds of the peach

Note the cluster of buds of which are of commercial importance, while others do not rank so high. A comparative study of the buds and branches of each type will aid in bringing out the differences.

1. North China race. The North China race (Amygdalus persica) includes the following varieties: Albert, Chinese Cling, Elberta, Smock, Spottswood, Thurber, Ford, Family Favorite, and others. The original parent of this race is almost a dwarf. The trees bloom later than the Persian types, and the flowers are nearly always larger. The foliage hangs on well during drought, but sheds off early in the fall. This race is supposed to have originated in northern China, and is adapted to zones north of those suited to the Spanish race.

a. Secure branches from several varieties of this race and make a drawing, natural size, and four inches in length, showing both the flower bud and the branch bud. How are the buds arranged? Describe.

b. Select a fruit bud and a branch bud, taking care that both are mature and perfect, and make a drawing, one inch in length, 
A STUDY OF BUDS

STUDENT'S NOTES AND REPORT 


\section{LABORATORY MANUAL OF HORTICULTURE}

of each. What difference is observed between the two? How are they arranged, and where do you find the branch buds with reference to the fruit buds? Describe the scales and pubescence of the buds?

c. Make a longitudinal and a cross section of both a flower bud and a branch bud. How do the flower buds and the branch buds differ in internal and in external structure? How many ovules are present in a flower bud? Is the number constant or variable? How old is the wood on which the flower buds are found? Does the age of the wood on which the flower buds are borne differ from that of the other fruits studied?

2. Persian race. The Persian race (Amygdalus persica) includes the following varieties: Lemon, Alexander, Conkling, Crawford's Late, Golden Drop, Old Mixon Free, St. John, Salway, Scott, Mountain Rose, Hale Early, and several others.

The trees of this race are of medium size, with short, thick limbs. The bark on the young wood is usually a rich purplish red. The bloom is variable, and the foliage is crumpled and has a purplish tinge. The trees require a long period of rest. The fruit is highly colored and of good flavor. This race is best adapted to northern sections and is not recommended for Southern planting.

a. Study branches from several of the above-named varieties. Make a drawing, natural size, and four inches in length, showing the details of the branch and of the fruit buds and branch buds. How are the buds arranged, and does this arrangement differ from that of the North China race? What is the color of the bark on the small branches? Is the color constant or variable?

b. Make a drawing, at least one inch in length, of both a flower bud and a branch bud. Compare the buds with those of the North China race in respect to size. Describe.

3. South China race. The South China race (Amygdalus persica) includes the following varieties: Honey, Pallas, Climax, Coleman, Early China, and others.

The trees are of medium size, and the branches come out at an angle of about fifty degrees and are less willowlike than the Peen-to. The bloom is large and profuse. This race is valuable for Southern planting.

Secure branches from one or more of the above varieties and study carefully. Make a drawing, natural size, and four 
A STUDY OF BUDS

\section{STUDENT'S NOTES AND REPORT}




\section{LABORATORY MANUAL OF HORTICULTURE}

inches in length, of a branch, including both fruit buds and branch buds. Describe the arrangement of the buds. What color is the young wood?

4. Spanish race. The Spanish race (Amygdalus persica) includes the following varieties: Cobler, Columbia, Victoria, Texas, Sanders, and several others. The trees are very large; the limbs large, long, and spreading; the branches low ; the flowers usually large; the foliage small and flat. The fruit is very decided in character, very late, and nearly always yellow. This race is adapted to isothermal lines north of those in which the South China race flourishes.

Secure branches from one or more varieties of this race. Study carefully. and compare with the races already studied. Make a drawing, natural-size, and four inches in length, of a branch, showing the position and arrangement of the buds. Describe any differences in this respect between this race and the others studied. What is the color of the bark? Where do you find the fruit buds?

5. Peen-to race (Amygdalus platycarpa). The Angel and the Waldo are two varieties which are seedlings of the Peen-to. This is probably the least important race, and the varieties are restricted as to the location in which they will grow. The trees are rather large and vigorous, with willowlike branches and large flowers.

Secure branches from one-year-old and two-year-old wood of the above varieties. Make a drawing, natural size, and four inches in length, of a branch, showing both leaf and branch buds. Describe fully. Compare this race with the South China race, and describe any difference.

Comparative study of the peach. Describe in detail the differences between the races - in the twigs, in the leaf and flower buds, in the color of the branches, in the position and arrangement of the buds, etc. - as seen by your study.

\section{REFERENCES :}

Bailey, "The Pruning Book," pp. 50-54.

Bulletin No. 39, Texas Agricultural Experiment Station. 
A STUDY OF BUDS

STUDENT'S NOTES AND REPORT

[65 ] 


\section{EXERCISE XX}

\section{A STUDY OF BUDS-POMACEOUS FRUITS}

Material. Branches of several varieties each, of the apple, pear, and quince, bearing both leaf and fruit spurs.

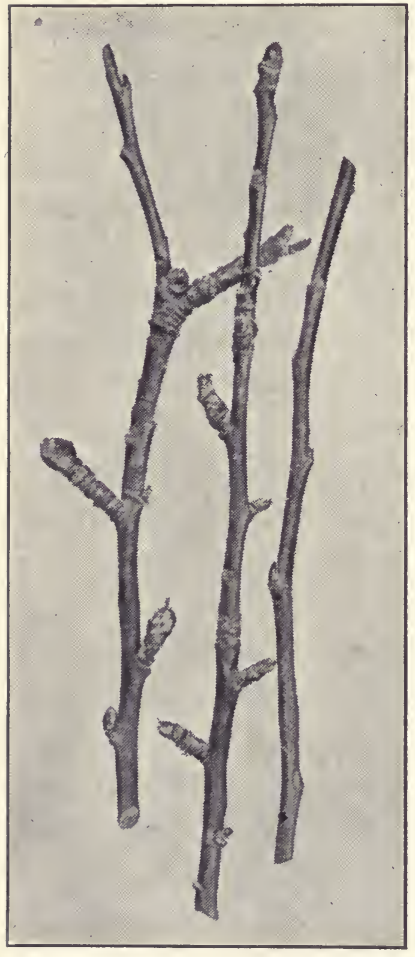

Frg. 14. Fruit buds and branch buds of the apple

Note the fruit spurs and branch spurs and compare them with those of the pear (Fig. 15)
Apparatus. Razor and lens.

Apples and pears are classed with a natural group of plants in which the fruit is more or less fleshy and contains seed cells inclosed in parchmentlike carpels. The apple, pear, and quince, so similar in many respects, belong to this class. This genus is called Malus, and includes many species of apples and crab apples. Malus sylvestris, the apple, includes many varieties. Pyrus communis and Pyrus sinensis, the pear, also include many varieties. Cydonia vulgaris, the quince, is not so important, but for convenience it is placed with the apple and the pear.

The varieties of all three of these fruits are numerous, and the difference in relationship is very slight.

\section{The Apple (Malus sylvestris)}

Branches of the following varieties are suggested: Northern Spy, Ben Davis, Wolf River, Early Harvest, Fameuse, Jonathan, Lady, Spitzenburg, Duchess of Oldenburg, Pippin, Greening, Russet, Bellflower.

1. Make a drawing, natural size, and four inches in length, of a twig, including the branch buds and leaf spurs, of at 
A STUDY OF BUDS - POMACEOUS FRUITS STUDENT'S NOTES AND REPORT 


\section{LABORATORY MANUAL OF HORTICULTURE}

least four varieties. Describe the difference between a branch bud and a leaf spur.

2. Draw at least three fruit spurs, including the branch, natural size, and four inches in length. What difference do you note externally between the branch bud and the fruit bud? Is

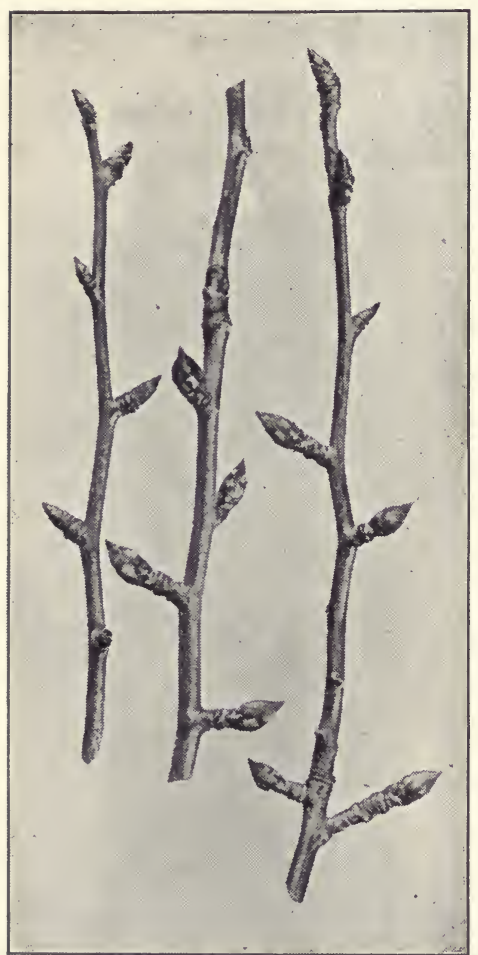

Frg. 15. Branch buds and fruit buds of the pear

Note the fruit spurs and leaf spurs there any difference in size, shape, or position of the branch bud and the fruit bud? Describe fully. How are the buds constructed? Study carefully the differences between the leaf spur and the fruit spur. How does the bud on the leaf spur differ from the bud found on one-yearold wood?

3. Tear the buds apart, and draw a separate scale from both the fruit bud and the branch bud. Describe any difference between the scale found on the branch bud and that found on the fruit bud.

4. Now with a very sharp knife make a longitudinal and a cross section of a branch bud and of a fruit bud. Make a separate drawing, at least one inch in length, of each. Can you detect any flowers or embryonic fruit? Describe the difference as seen in a cross section of both the fruit bud and the branch bud. Describe any varietal differences observed from your study.

\section{The Pear (Pyrus communis and Pyrus sinensis)}

Study the pear in the same way as the apple. Varieties suggested: Bartlett, Seckel, Sand pear, President, Kieffer, Anjou, Angoulême.

1. Make drawings, natural size, and four inches in length, showing both the fruit spurs and the leaf spurs of at least four 
A STUDY OF BUDS-POMACEOUS FRUITS

STUDENT'S NOTES AND REPORT 


\section{LABORATORY MANUAL OF HORTICULTURE}

varieties. Is there any difference between the fruit spurs of the pear and of the apple? Describe fully. What differences do you note in the fruit bud and in the branch bud of each. Describe the difference in the color of the bark, in the pubescence, and in the lenticels, etc., as seen in the different varieties.

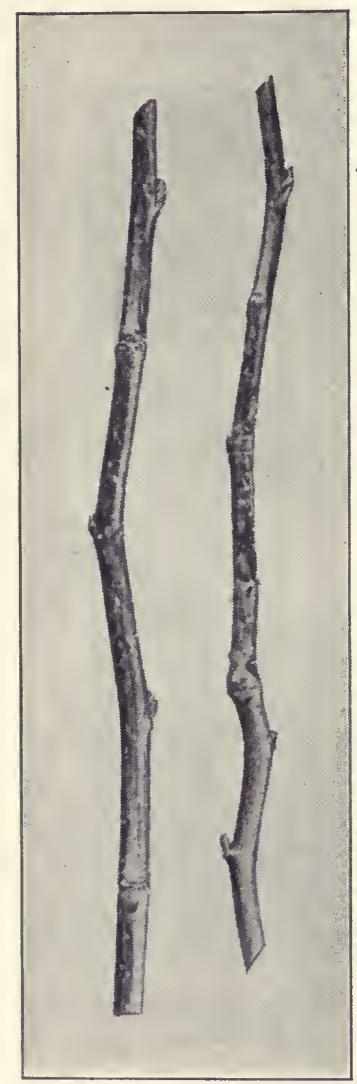

Fig. 16. Branches of the quince, showing the buds

2. Make a drawing, two inches in length, showing the leaf scars. Explain the cause of these scars.

3. Draw a cross section, at least one inch in length, of a branch bud and a fruit bud. Cut a longitudinal and a cross section of both the fruit bud and the branch bud and describe any differences between the pear and the apple. Note and describe any varietal differences. How do the fruit spurs of the apple and pear differ from those of the cherry and plum?

\section{The Quince (Cydonia vulgaris)}

The quince is a fruit similar in structure to the apple and the pear. It is borne upon small, irregular-growing trees from ten to twelve feet high, and is a most excellent fruit for preserves.

Study the quince in the same way as the apple and the pear. The following varieties are suggested: Orange, Chinese, Portugal, Champion, Angers.

1. Make a drawing of a branch, four inches in length. How does the branch of the quince differ from that of the apple and the pear?

2. Make a longitudinal and a cross section of a bud, one inch in length. Where are the fruit buds found, and how do they differ in position from those of the apple and the pear? Where are the branch buds found? Describe.

3. Describe fully the difference in the buds of the three fruits in respect to position, structure, size, and shape.

REFERENCE :

Bailey, "The Pruning Book," pp. 30-46. 
A STUDY OF BUDS-POMACEOUS FRUITS

STUDENT'S NOTES AND REPORT 


\section{EXERCISE XXI}

\section{A STUDY OF BUDS - VINE FRUITS}

Material and apparatus. Canes of the grape, showing welldeveloped buds; razor, lens.

\section{The Grape (Vitis sp.)}

The grape is one of our oldest fruits. The history of the Old World grape goes back to prehistoric times. Grape seeds have

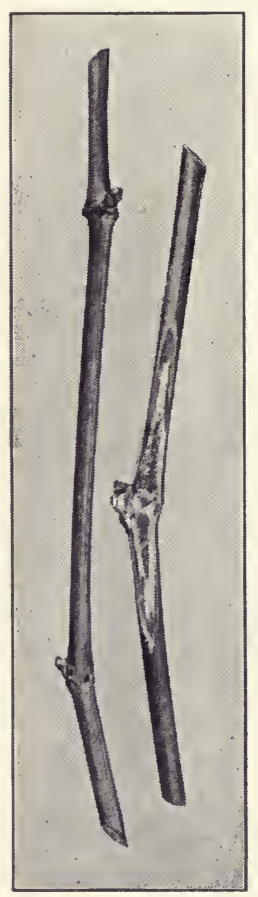

Fig. 17. Grape canes, showing the buds

been found in the remains of the Swiss lake dwellings of the bronze age, and the original habitat of the grape is supposed to have been about the Caspian Sea. Several species of grapes are recognized, but the two of greatest commercial importance are the Vitis vinifera, or the Old World grape, and the Vitis labrusca, or the New World grape. There are many hybrids between these two.

Vitis labrusca. Varieties suggested for study: Black Hawk, Champion, Chautauqua, Colerain, Concord, Cottage, Eaton, Glenfeld, Hosford, Moore Early, Lutie, Lucile, Wyoming, Worden, Vergennes.

1. Secure canes of one or more of the above varieties, and study carefully. Make a drawing of a cane, natural size, including at least two buds. Describe the position and the arrangement of the buds. What is the color of the bark? Describe. Make a drawing, at least one inch in length, of a bud. How does this bud differ from the bud of the cherry and of the apple? Describe the bud scales.

2. Make a longitudinal and a cross section of a bud. Describe the internal structure. Is this a fruit bud or a leaf bud? Where is the fruit borne on the grape? Describe fully. 
A STUDY OF BUDS - VINE FRUITS

STUDENT'S NOTES AND REPORT 


\section{LABORATORY MANUAL OF HORTICULTURE}

3. Make a longitudinal section of a cane, through a node, and show by a drawing the internal structure. Label the pith, bark, and wood. What proportion does the bark bear to the pith? Can you locate the diaphragm which is found at the node, after a longitudinal section of the cane is made? Label. Describe.

Vitis vinifera. Varieties suggested for study: Black Hamburg, Tokay, and Malaga.

1. Secure canes from one of the above varieties, and study them critically. Make a drawing, natural size, of a cane, including at least two buds. Describe the buds and the bark. Make a drawing, at least one inch in length, of a bud. Describe the difference between the labrusca and the vinifera. What differences do you observe in the bud and the cane of each? Where are the vinifera types of grapes grown?

2. Make a longitudinal section of a cane, showing the diaphragm. Does the diaphragm of the vinifera differ from that of the labrusca? Describe.

Vitis labrusca $\times$ vinifera. Varieties suggested for study: Brighton, Campbell Early, Catawba, Diamond, Essex, Goethe, Hartford, Herbert, Iona, Isabella, Lady Washington, Jefferson, Woodruff.

This group includes many good varieties of grapes which have originated by the crossing of the vinifera with the labrusca. The characteristics are derived from both of the parents, but some varieties show more characteristics from the male, others more from the female.

1. Secure canes from one or more of the above varieties, and study carefully. Make a drawing of a cane, including at least two buds. How do these buds differ from those of Vitis labrusca and Vitis vinifera? Can you see any resemblance to either parent? Study carefully, and note which parent they seem to resemble the most. Make a drawing, at least one inch in length, of a bud. Describe.

2. Draw a longitudinal section of a cane, showing the diaphragm. Describe. Describe in detail the differences between the Vitis labrusca, the Vitis vinifera, and the cross between the two.

References :

Bulletin No. 193, California Agricultural Experiment Station.

Circular No. 16, New York Agricultural Experiment Station. 
A STUDY OF BUDS-VINE FRUITS

STUDENT'S NOTES AND REPORT 


\section{EXERCISE XXII}

\section{PRUNING}

Material and apparatus. Small orchard; pruning-saw, pruningknife, pruning-shears, long-handled pruner.

After the student has become thoroughly familiar with the different kinds of buds of the several fruits and is able to distinguish a fruit bud from a branch bud, or a fruit spur from a leaf spur, several exercises should be given in the general practice of pruning. It is advisable to have at least one exercise each on the pruning of the apple, the cherry, the peach, and the grape. Study carefully each kind of plant pruned. Discuss fully what is the essential thing for which to look. Discuss the differences between the fruit bud and the branch bud as seen from your practice in pruning. Discuss fully what kind of a cut should be made in every case. Discuss why it is essential, when cutting a large limb, to make a cut first on the underside. Discuss why the peach must be pruned differently from the apple. Tell why the grape should be pruned back to three or four buds. On what age of wood are the fruit buds of the peach, the pear, the grape, and the cherry usually found. Compare several of the different kinds of pruning-saws. Give the advantages and the disadvantages of each. Tell where the pruning-shears should be used and where they should not be used.

\section{References :}

Bailey, "The Pruning Book," chap. iv.

Farmers' Bulletin No. 181, United States Department of Agriculture.

Paddock and Whipple, "Fruit Growing in Arid Regions," pp. 81-100.

Thomas, "The American Fruit Culturist," chap. vii. 
PRUNING

STUDENT'S NOTES AND REPORT

[77] 


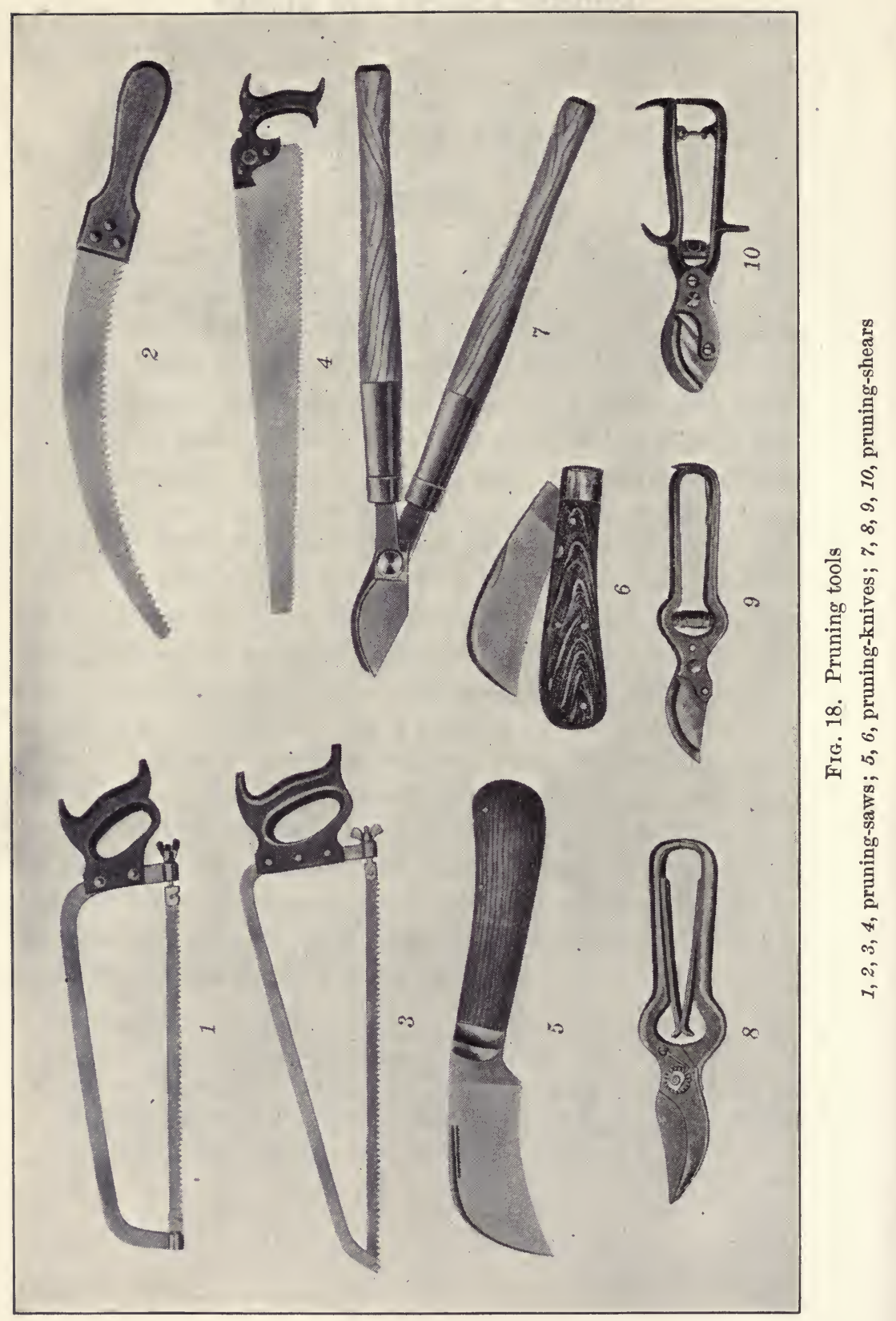

[ 78 ] 
PRUNING

STUDENT'S NOTES AND REPORT

[79] 


\section{EXERCISE XXIII}

\section{THE PRUNING OF THE APPLE}

Material and apparatus. Small orchard; pruning-saw, pruningknife.

Discuss the pruning of the apple and give the reason for each step. Discuss how a one-year-old tree must be pruned; a twoyear-old tree; a five-year-old tree; a mature tree. How is a low-headed tree formed? When should the head be started? Discuss. Give the advantages and the disadvantages of a lowheaded and a high-headed tree.

- REFERENCES :

Thomas, "The American Fruit Culturist," pp. 98-109.

Waugh, "The American Apple Orchard," chap. ix. 
THE PRUNING OF THE APPLE

STUDENT'S NOTES AND REPORT 


\section{EXERCISE XXIV}

\section{THE PRUNING OF THE PEAR}

Material and apparatus. Small pear orchard; pruning-saw, pruning-knife.

Discuss the pruning of a one-year-old tree, a two-year-old tree, a ten-year-old tree, and a mature tree. How does the pruning of the pear differ from that of the apple? Discuss in detail.

REFERENCES :

Bailey, "The Pruning Book," pp. 269-278.

Paddock and Whipple, "Fruit Growing in Arid Regions," pp. 133-138. 
THE PRUNING OF THE PEAR

STUDENT'S NOTES AND REPORT 


\section{EXERCISE XXV}

\section{THE PRUNING OF THE PLUM AND THE CHERRY}

Material. Small plum and cherry orchard.

Apparatus. Pruning-saw, pruning-knife.

Discuss the pruning of the plum and the cherry. What different methods are practiced on the two kinds of trees? How do these methods of pruning differ from those of the pear and the apple?

REFERENCES :

Paddock and Whipple, "Fruit Growing in Arid Regions," pp. 139-141. Thomas, "The American Fruit Culturist," p. 109. 
THE PRUNING OF THE PLUM AND THE CHERRY

STUDENT'S NOTES AND REPORT 


\section{EXERCISE XXVI}

\section{THE PRUNING OF THE PEACH}

Material and apparatus. Small peach orchard; pruning-saw, pruning-shears.

Give in detail the proper method to follow in the pruning of the peach. How does this' differ from the method used for the apple and the cherry? Where is the fruit-bearing wood found? Discuss.

\section{RefERENCES :}

Bulletin No. 159, Maryland Agricultural Experiment Station, pp. 121-136.

Bulletin No. 55, Missouri Agricultural Experiment Station.

Paddock and Whipple, "Fruit Growing in Arid Regions," pp. 102110, 127-132. 
THE PRUNING OF THE PEACH STUDENT'S NOTES AND REPORT 


\section{EXERCISE XXVII}

\section{THE PRUNING OF THE GRAPE}

Material and apparatus. Small vineyard; pruning-shears, pruning-knife.

Discuss in detail the pruning of the grape. Where are the fruit buds found? Do they occur on the present season's wood or later? Tell why it is advisable to prune the grape to three or four buds. Does this method of pruning reduce the yield of the crop? Is it an advantage or a disadvantage to use this method? Discuss. Describe in detail each of the following methods :

1. Renewal system of pruning.

2. Marvin's system of fan pruning.

3. Kniffin system of pruning.

4. Y-trunk Kniffin system of pruning.

5. Double Kniffin system of pruning.

6. Overhead Kniffin system of pruning.

REFERENCES :

Bailey, "The Pruning Book," chap. viii.

Bulletin No. 193, California Agricultural Experiment Station.

Circular No. 16, New York Agricultural Experiment Station.

Year Book of the Department of Agriculture, 1896, pp. 499-542. 
THE PRUNING OF THE GRAPE

STUDENT'S NOTES AND REPORT

[89] 


\section{EXERCISE XXVIII}

\section{THE PRUNING OF THE BRAMBLES}

Material and apparatus. Small patch of brambles; bramble hooks and pruning-shears.

The blackberry, raspberry, and dewberry are classed as brambles. The method of pruning such plants is very different from the method used for tree fruits. Discuss the best method of procedure. What canes should be removed? Is there any disadvantage in using the bramble hook? If so, discuss. When should the brambles be pruned, and what canes should be removed?

ReFERENCES :

Bailey, "The Pruning Book," pp. 323-327.

Farmers' Bulletin No. 213, pp. 15-16. 
THE PRUNING OF THE BRAMBLES

STUDENT'S NOTES AND REPORT 


\section{EXERCISE XXIX}

\section{THE PRUNING OF THE BUSH FRUITS}

Material and apparatus. Small patch of currants and gooseberries; pruning-knife and pruning-shears.

The currant and the gooseberry are two of the most important of the bush fruits. The method of pruning these fruits is different from that used for tree fruits. After some practice in the field discuss the best ways in which the bush fruits are pruned. What wood should be removed each year? Should the plants be severely headed back, or thinned out by the removal of the older canes? Is it wise to keep approximately a definite number of canes in each clump? Discuss.

\section{REFERENCES :}

Bailey, "The Pruning Book," pp. 327-333.

Bulletin No. 35\%, New York Agricultural Experiment Station. 
THE PRUNING OF THE BUSH FRUITS

STUDENT'S NOTES AND REPORT

[93 ] 


\section{EXERCISE XXX}

\section{THE STUDY OF SHIELD AND PRONG BUDDING}

Material. Bud sticks, stocks of the peach or willow (preferably steamed, if the exercise is practiced in the laboratory).

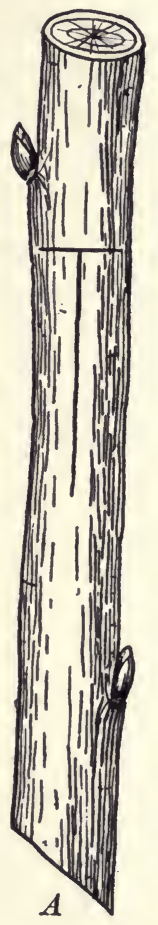

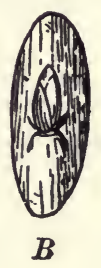

Fig. 19. Shield budding

$A$, the stock, showing the longitudinal and the transverse cut; $B$, the bud removed from the bud stick and ready to be inserted into the stock; $C$, the stock, showing the bud in position ready for tying

Apparatus. Raffia or

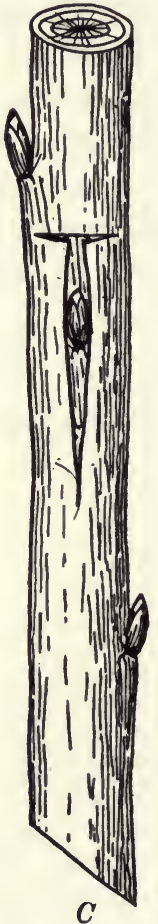
grafting-cord, buddingknife.

Budding is the operation of applying a single bud, bearing little or no wood, to the surface of the growing wood of the stock. The bud is applied directly to the cambium layer of the stock. It is usually inserted under the bark, but in some forms of budding the bud is used to cover the wound made on the stock. Plants with thin bark and plenty of sap are likely to do better when budded than plants with thick, heavy bark.

\section{SHIELd BudDing}

This is the style of budding that is in general use, and the one that

is the most often practiced. It is known as shield budding, from the shieldlike shape of the portion of bark bearing the bud. Secure small branches, about three eighths of an inch in diameter, of either the peach or the willow. If the exercise is 
THE STUDY OF SHIELD AND PRONG BUDDING STUDENT'S NOTES AND REPORT 
desired in the winter, the steaming of the wood will be found to loosen the bark so that it will slip. Now hold the branch firmly with the left hand and with the right make a clean, sharp cut, with a budding-knife, through to the wood and one third of the distance around the twig. Now, by another operation, make a straight cut, about one inch in length, at right angles to the one just finished. The two cuts now form a letter T (see Fig. 19). With the budding-knife carefully peel the bark back, down to the wood, thus breaking the cambium layer. Take a bud stick

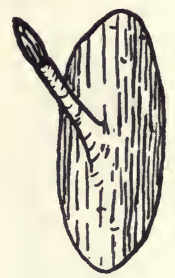

Fig. 20. Prong bud ready to be inserted into the stock which has previously been procured and, holding it in the left hand, carefully cut a bud from the stick. The bark, including the bud, should be about one inch in length. It should contain as little as possible of the wood of the stick. Now insert the bud into the cut made in the stock, place the bark over the bud, and tie the whole firmly with raffia or grafting-cord.

Make three drawings, four inches in length, to show first, the longitudinal and the cross cut; second, the bud in place; and third, the bud wrapped. Make two natural-size drawings of the bud after it has been removed from the bud stick, the first a front view, showing the shieldlike shape of the portion of the bark; the second a side view, showing the width of the bark bearing the bud. Label all drawings.

\section{Prong, or Twig, Budding}

This is a modification of shield budding in which a short prong, or spur is used in the place of a simple bud. The bud is cut in essentially the same manner as for shield budding.

Secure for your bud stick small branches of the walnut tree, or any other tree having short prongs, or spurs. By the same operation as in shield budding remove the prong bud. The incision into which the prong bud is placed is identical with that of the shield bud. Make two drawings, natural size, of the prong bud, showing the front and side views. Label. Discuss.

\section{REFERENCES :}

Bailey, "The Nursery Book," pp. 94-107.

Goff, "Principles of Plant Culture," pp. 230-234.

Farmers' Bulletin No. 15\%, pp. 21-23. 
THE STUDY OF SHIELD AND PRONG BUDDING STUDENT'S NOTES AND REPORT 


\section{EXERCISE XXXI}

\section{THE STUDY OF PLATE BUDDING AND H-BUDDING}

Material. Bud sticks, stocks of the peach or willow.

Apparatus. Budding-knife, raffia or grafting-cord.

\section{Plate Budding}

This form of budding is used on certain plants where the shield bud is not successful.

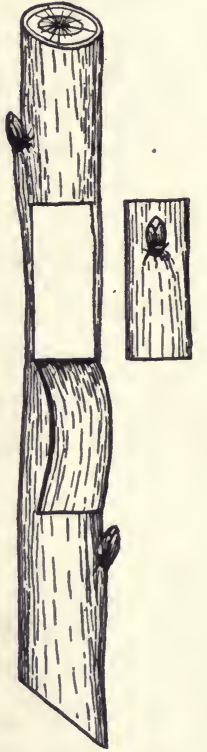

Fig. 21. Plate bud, showing the stock with the bark turned back and the bud ready for insertion

Secure branches of either the peach or the willow, about one-half inch in diameter or a trifle larger and of any convenient length. With the budding-knife make a rectangular incision, three fourths of an inch in length and one fourth to three eighths of an inch in width, in the stock through the bark to the wood (Fig. 21), and turn down the flap of bark. Now cut a section of bark including a wellformed bud, similar in shape to the rectangular section in the stock. The bud on the bark should be about twice as far from the bottom as from the top of the bark. No wood should be attached to the bark containing the bud. Now place the bud under the flap of bark so that the cambium layer of the bud and the stock are in close apposition, and turn the flap over the bud and tie firmly. The operation is now complete.

Make a drawing, four inches in length, showing the stock with the flap of bark cut and turned down. Label all parts. Make a drawing of the bud twice its natural size, and label. Make another drawing, four inches in length, showing the stock with the bud in place and wrapped. Describe fully each operation. On what kind of plants is this form of budding used? Discuss. 
THE STUDY OF PLATE BUDDING AND H-BUDDING STUDENT'S NOTES AND REPORT 


\section{LABORATORY MANUAL OF HORTICULTURE}

\section{H-BUDDING}

This form of budding is a modification of plate budding. In $\mathrm{H}$-budding a flap is formed both above and below the horizontal cut on the stock, which covers the bud from

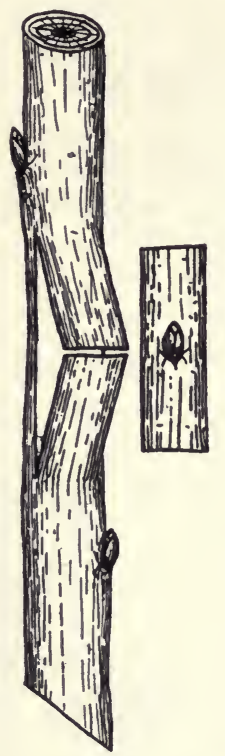

Fig. 22. H-Budding, showing the stock and the bud both ends. This allows the more perfect fitting of the bark around the bud.

Secure a small branch, similar to that used in plate budding, and make the same cut as in plate budding, but, instead of forming one flap, continue your longitudinal cuts equal distances on each side of the transverse cut. Now with the budding-knife peel the bark in opposite directions from the transverse cut, forming the letter $\mathrm{H}$ (Fig. 22). Proceed to cut your bud, including a piece of bark the size of the opening made by turning back both flaps of the bark on the stock. Cut the bark including the bud in such a manner that the bud is in the center of the bark. Now place the cambium layer of the bud and of the stock together and tie the two flaps of bark on the stock firmly around the bud. At least a dozen trials should be made to insure good technique and ease of operation. Make a drawing of the stock, four inches in length, showing the cut, with both flaps of bark turned back. Make a drawing of the bud, showing the front and the side view. Label. Describe fully each operation. 
THE STUDY OF PLATE BUDDING AND H-BUDDLNG

\section{STUDENT'S NOTES AND REPORT}




\section{EXERCISE XXXII}

\section{THE STUDY OF FLUTE BUDDING, RING BUDDING, AND CHIP BUDDING}

Material. Bud sticks, stocks of the peach or willow. Apparatus. Raffia or grafting-cord, budding-knife.

\section{Flute Budding}

Flute budding is a form of budding ocasionally employed on certain plants. It differs from the other forms in that a portion

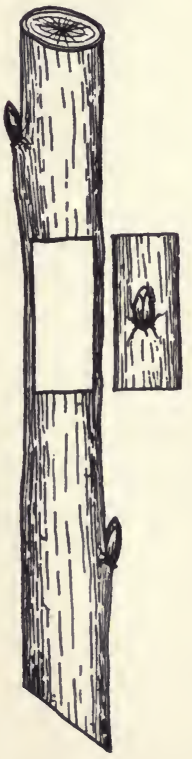

Fig. 23. Flute budding, showing the stock and the bud of the bark is removed entirely from the stock and a similar piece is fitted into its place. The section of bark removed extends only part of the way around the stem (Fig. 23).

Secure a small branch about one half to five eighths of an inch in diameter, and with the budding-knife remove a section of the bark about one inch in length and about one third of the diameter of the stock in width. The cut necessarily varies somewhat in size, according to the size of the stock which is to be budded, but the usual size is about one inch in length and from one third to one half of the distance around the stock. Now remove a piece of bark containing a healthy, vigorous bud and cut it to the exact size of the wound on the stock. Do not remove any wood with the bark containing the bud. Place the bud over the wounded surface on the stock and tie it firmly. The operation is now complete. Make a drawing of the stock, four inches in length, showing the front and side views. Label all parts, and give the dimensions of the cut surface. Make a natural-size drawing of the bud. Label and describe. 
FLUTE BUDDING, RING BUDDING, AND CHIP BUDDING STUDENT'S NOTES AND REPORT 


\section{LABORATORY MANUAL OF HORTICULTURE}

\section{Ring, or Annular, Budding}

This is a modification of flute budding, the difference being that the portion of bark removed extends entirely around the

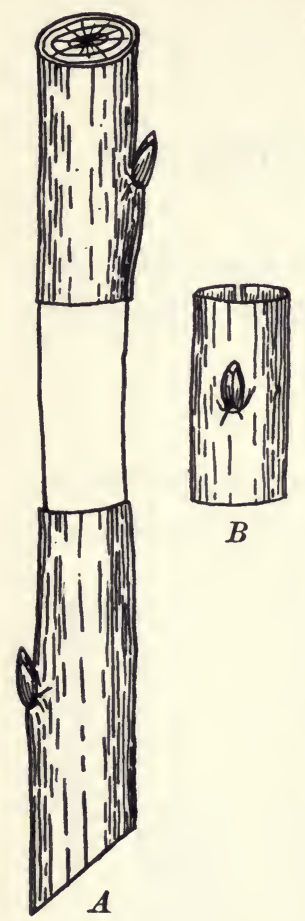

Fig. 24. Ring budding $A$, stock, showing the ring of bark removed; $B$, bud ready to be placed on the stock stock, forming a ring; hence the name. The same size stocks should be used as for flute budding.

Secure stocks of the same size as in flute budding, and with the budding-knife remove a ring of bark, about one inch in length, from the stock. Secure the plant from which you wish to bud, and remove a piece of the bark bearing a healthy bud, the same size as the wound on the stock. The bark bearing the bud should be split lengthwise on the side opposite the bud. The bud should occupy the central portion of the bark. Why? Make a drawing of the stock, natural size, and four inches in length, showing the portion of bark removed. Label, and give the dimensions of the bud. Make a natural-size drawing of the bud, showing the ring character. Label. Discuss the advantages and the disadvantages of this method.

\section{Chip Budding}

This is a form of budding that is used when the stock is dormant and the bark will not slip. The chip bearing the bud is held in place by tying or, still better, by the use of grafting-wax.

Secure small stocks the same as those employed in flute budding and make an incision into the stock similar to that in Fig. 25. The cut in the stock should be smooth, clean, and even,

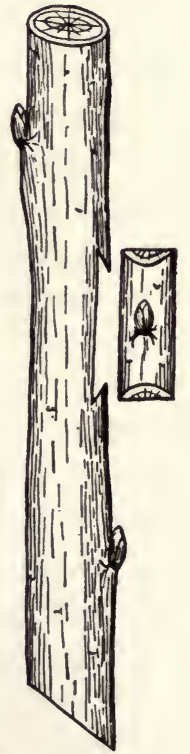

Fig. 25. Chip budding, showing the cut in the stock and the bud ready to be inserted 
FLUTE BUDDING, RING BUDDING, AND CHIP BUDDING STUDENT'S NOTES AND REPORT 


\section{LABORATORY MANUAL OF HORTICULTURE}

and about one inch in length and from three eighths to one half of an inch in width. The depth of the cut should not exceed one eighth of an inch, and the bud when inserted should be flush with the bark of the stock. Now with the budding-knife remove the bud with sufficient wood so that it will fit snugly into the cut made in the stock. It is important that at least two sides of the bud should be in close apposition with the sides of the stock and that the cambium layers of the bud and the stock should meet at several points.

Make a drawing of the stock, four inches in length, showing the front and the side views. Draw a front and a side view of the bud, give the dimensions, and label. Discuss the operation and tell what kind of plants are propagated by this method. 
FLUTE BUDDING, RING BUDDING, AND CHIP BUDDING STUDENT'S NOTES AND REPORT 


\section{EXERCISE XXXIII}

\section{THE STUDY OF GRAFTING-WAXES}

Material. Resin, beeswax, rendered beef tallow, raw linseed oil, white resin, alcohol, turpentine, Burgundy pitch, red ocher, white pitch, Venetian red, No. 16 white knitting-cotton.

Apparatus. Granite kettle, small pail, cooking-burner.

Grafting-waxes are used for the protection of wounds and for the covering of wounded surfaces when certain kinds of grafts are made. Grafting-waxes are made by the following methods:

\section{Beeswax and Resin Waxes}

Formula 1. Weigh out one pound of resin, one half of a pound of beeswax, and one fourth of a pound of rendered beef tallow. Place the ingredients in a granite or an iron kettle and allow them to melt, then boil for about one minute, or until the mass is thoroughly mixed. Remove from the fire, and pour the melted mass directly into a pail of cold water. When the mass is cold enough to handle, gather it into a ball and work it with the hands until it assumes a light-brown color. Grease the hands thoroughly with tallow before working, to prevent the wax from sticking to them. Why is the melted wax poured into the water? What is the purpose of the molding and working with the hands? It is important that pure beeswax be used and not wax which has been adulterated with paraffin. Why? Does the wax aid in the healing of a wound? Discuss.

Formula 2. Weigh out one pound of resin, one fourth of a pound of beeswax, one fourth of a pint of raw linseed oil. Place the ingredients in a granite kettle and allow them to melt gradually. When the mass is thoroughly melted and incorporated, pour it into a bucket containing cold water, and treat as above. After twenty-four hours examine both batches and describe fully the differences, if any. Explain.

Grafting-cord. Often in the making of root grafts and occasionally in budding, grafting-cord is needed. This is made 
THE STUDY OF GRAFTING-WAXES

STUDENT'S NOTES AND REPORT 
by securing a ball of No. 16 knitting-cotton and placing it in the kettle of melted wax of Formula 1. Allow the ball of cotton to remain in the melted wax for at least five minutes, or until it is completely saturated. The ball should be turned frequently, in order to insure complete saturation. When finished, allow it to cool, and wrap in oiled paper for future use.

Why is cord prepared in this way superior for grafting purposes to the ordinary wrapping-twine?

\section{Alcoholic Waxes}

Formula 3. Weigh out one and one-half pounds of white resin and one fourth of a pound of beeswax. Place the ingredients in a granite kettle and heat them until they are thoroughly incorporated. Remove the mass from the fire and stir until partially cooled. Now gradually add enough alcohol to give to the mass, when cooled, the consistency of thick paint. Describe the color and the appearance of this wax and tell where it can best be used.

Formula 4. Weigh out one-half pound of white resin and onehalf ounce of rendered beef tallow. Heat the two substances together until they are incorporated. Remove from the fire, cool, and add one teaspoonful of turpentine. Stir the mass until thoroughly mixed, and gradually add enough alcohol to make the mass assume the consistency of thick honey. (From six to eight fluid ounces of 95 per cent alcohol will usually be sufficient.)

What are the differences between formulas 3 and 4 ? Describe the appearance of the two waxes, and give your opinion as to which is the best.

\section{Pitch Wax}

Formula 5. Weigh out twelve ounces of resin and six ounces of Burgundy pitch and melt them together in a granite kettle, stirring thoroughly. At the same time melt three ounces of rendered beef tallow in another vessel. Pour both liquids together while hot, and stir thoroughly. To this mass add four or five ounces of red ocher, and stir the mixture until it is smooth and until the different ingredients are completely incorporated. Describe the mass and tell when and where it should be employed.

Note. The linseed oil should be entirely free from cottonseed oil.

These grafting-waxes may be made by groups of from two to four students.

[110] 
THE STUDY OF GRAFTING-WAXES

STUDENT'S NOTES AND REPORT 


\section{EXERCISE XXXIV}

\section{THE STUDY OF SPLICE, WHIP, AND DOUBLE-WHIP GRAFTING}

Material. One-year-old apple-seedling roots, scions from apple trees.

Apparatus. Sharp budding-knife, raffia or grafting-cord.

Grafting is the operation of inserting into a stock a scion or twig comprising one or more buds. It is classified in various ways, chiefly with reference to the method in which the scion and the stock are joined.

The union of the scion with the stock depends upon the growing together of the cambium tissue of the two plants. This tissue is the living active cells found between the bark and the wood. It is composed of cells which are actively dividing. The layer of cambium tissue is very narrow, being only four or five cells in thickness. It is very essential that careful and painstaking work be done and that the student be thoroughly familiar with the position the cambium layer occupies in both the stock and the scion.

The scions are cut in the late fall, in winter, or at any time before the buds swell in the spring. It is thought, however, that the later the scions are taken from the tree before the buds swell, the greater will be the success in grafting, other things being equal. Each scion should contain from three to five welldeveloped buds, and it should be cut about one-half inch above and below a bud. Only the previous year's growth is used in all ordinary cases, but an exception to this is found in the maples and several of the ornamentals in which the older wood may be used.

The scions should be stored in moss, sand, or sawdust and kept in a cool place until they are used to prevent drying out or swelling of the buds. This is very important for successful grafting. Only well-formed branch buds should be used.

\section{Splice Grafting}

Splice grafting represents the simplest form of grafting. In this form the scion and the stock should be as nearly the same size as it is possible to get. In splice grafting it is well to use 
SPLICE, WHIP, AND DOUBLE-WHIP GRAFTING STUDENT'S NOTES AND REPORT 
one-year-old apple seedlings, and scions taken from apple trees. The two parts, namely, the stock and the scion (Fig. 26), are simply cut diagonally across and the two firmly tied together.

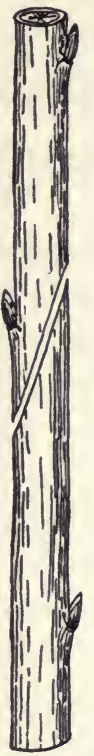

Fig. 26. Splice grafting, showing the relative size of the stock and the scion

The cut should be one inch to one and one-half inches across. This form of grafting is frequently employed upon plants with soft or tender wood which will not admit of splitting.

Make a drawing, natural size, and three inches in length, of both the stock and the scion, showing the parts in position ready for tying. How long did you make the diagonal cut? Place the dimensions on your drawings. To what kind of stock is this method of grafting best adapted? Practice by making a number of these grafts. Care must be taken that the cambium layers are in apposition. Why is this important? Discuss.

Whip, or Tongue, Grafting

This form of grafting is employed only on small stocks, one or two years old. The stocks are usually seedling roots, and the grafting is usually performed in the winter. Both the scion and the stock (Fig. 27) are cut diagonally across, as in splice grafting, and the cut should be at least one to one and one-half inches across, according to the size of the stock. A vertical cleft is then made in both the stock and the scion, and the two are joined by shoving the tongue of the
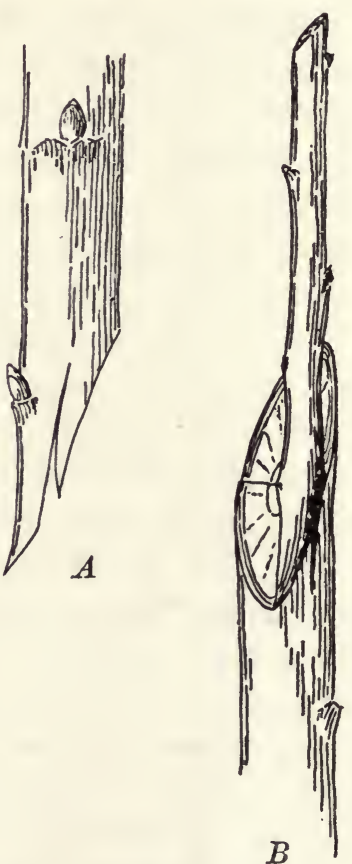

FIG. 27. Whip grafting

$A$, scion, showing the diagonal cut and the split; $B$, scion inserted into the stock scion into the cleft of the stock. The two parts are held together by tying with raffia or grafting-cord. If the wound stands above the ground, it must be protected by applying grafting-wax over the bandage. 
SPLICE, WHIP, AND DOUBLE-WHIP GRAFTLNG STUDENT'S NOTES AND REPORT 
1. Make a natural-size drawing of the root, showing the diagonal cut and the cleft. How long should this cut be? Place the dimensions on the drawing, and describe how the cut, which should be clean and even, is best made. Discuss.

2. Make a natural-size drawing of the scion, showing the cut and the cleft. The scion should contain three or four well-developed and plump buds. How long is the scion? Label all parts, and place the dimensions on your drawings.

3. Show by a natural-size drawing the stock and the scion tied in position. What size of stocks is best suited to this form of

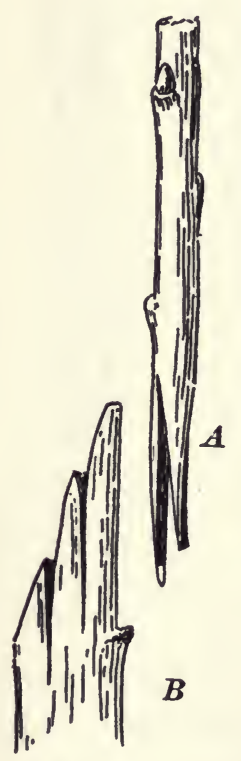

Fig. 28. Double-whip grafting

$A$, scion; $B$, stock, showing the double split; $C$, scion inserted into the stock

made instead of one (Fig. 28). The scion, having two supports in the stock, forms a more intimate contact with it. This method is usually too slow for general practice, but is good in special cases, particularly with some plants that are a little hard to graft.

Make a natural-size drawing of the stock and the scion.

Make a drawing of the stock with scion in position. Describe.

\section{ReFERENCES :}

Bailey, "The Nursery Book," chap. v.

Goff, "Principles of Plant Culture," pp. 219-230.

[116] 
SPLICE, WHIP, AND DOUBLE-WHIP GRAFTLNG

STUDENT'S NOTES AND REPORT 


\section{EXERCISE XXXV}

\section{THE STUDY OF CLEFT GRAFTING AND BARK GRAFTING}

Material. Stocks cut from apple or pear trees from one to two inches in diameter and from twelve to fifteen inches in length.

Apparatus. Grafting-chisel, sharp knife, grafting-wax.

These two forms of grafting are used principally for the topworking of old trees or for changing the variety of a large tree of

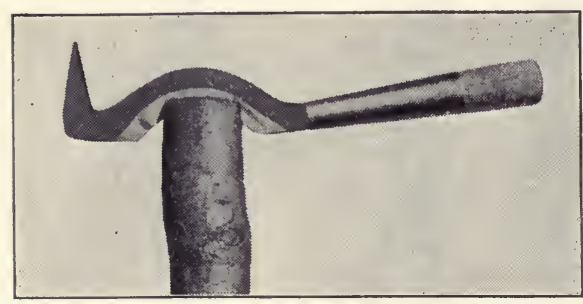

FIG. 29. A very good type of grafting-chisel, showing the first position in cleft grafting inferior flavor. Occasionally they are used to replace large broken limbs.

Cleft grafting is the form universally used in top-working or grafting in the limbs of a tree. It is limited to branches less than two inches in diameter, and is best suited to those between one inch and one and one-half inches in diameter.

The two essential parts in this form of grafting are the stub (Fig. 29), or that part of the branch on which the grafting is performed, and the scion (Fig. 33). The scion is a twig taken from oneyear-old wood, and should contain three or four strong, healthy buds. It is usually from four to six inches in length.

The scion is cut wedgeshaped, and the length of

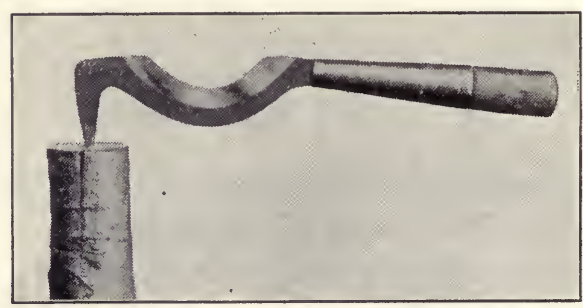

Fig. 30. The second position of the graftingchisel in cleft grafting the wedge should be not less than one inch, but the cut can vary from one to one and one-half inches. The cut must be smooth, and made by two draws of the knife. The outer edge is usually a little thicker than the inner one, to insure the scion being held firmly. 
CLEFT GRAFTING AND BARK GRAFTING STUDENT'S NOTES AND REPORT 


\section{LABORATORY MANUAL OF HORTICULTURE}

The limb, or stub, is split either by a grafting-chisel (Fig. 30), of which two kinds are in common use, or by the ordinary wood chisel. The essential requisite is to have the knife equipped with a curved edge so as not to split the bark but rather to cut it, and this is best accomplished by a curved blade.

\section{Cleft Grafting}

1. Practice making several clefts and inserting the scions.

Make a drawing, four inches in length and one and one-half inches in diameter, showing a stub and cut with the chisel in

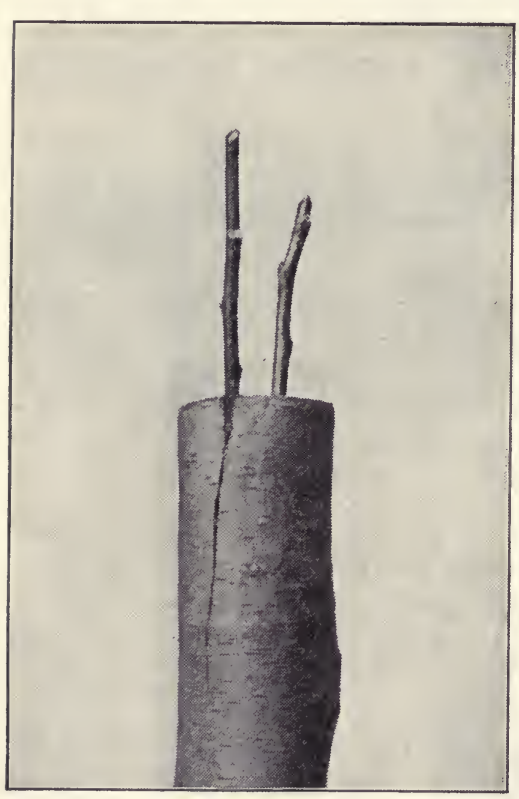

Fig. 31. Cleft graft, showing the scions in position in the stub before it is waxed over

position. Show the length of the split along the side. Does this vary with each graft? What is the reason for this variation? Where is the cambium layer in the stub found?

Cut your scions, and insert two in each stub, slanting them outward at an angle of four or five degrees (Fig. 31). Now wax the stub over with grafting-wax. The wax should extend over the edge about a quarter of an inch and completely fill the split on both sides. Why?

2. Make a natural-size drawing of the scion. What is the distance to the first bud? Why should a small portion of the wood be left above the last bud? The top of the wedge-shaped cut should be near a bud. Why this precaution? Where is the cambium layer in the scion? How do you insure the cambium layer of the scion coinciding with that of the stock? Discuss.

3. Make a drawing, four inches in length, showing the scions in the stub after they have been waxed over (Fig. 32). The two scions should slant outward at an angle of about five degrees. Why? What is the purpose of the wax? 
CLEFT GRAFTING AND BARK GRAFTING

STUDENT'S NOTES AND REPORT 


\section{LABORATORY MANUAL OF HORTICULTURE}

\section{Bark Grafting}

Bark grafting is employed on limbs that are too large for cleftgrafting. Limbs over two inches in diameter are best grafted in this way. Bark grafting is often employed to replace large limbs which have been destroyed.

The essential principle in this form of grafting is the same as that involved in cleft grafting. From three to twelve scions

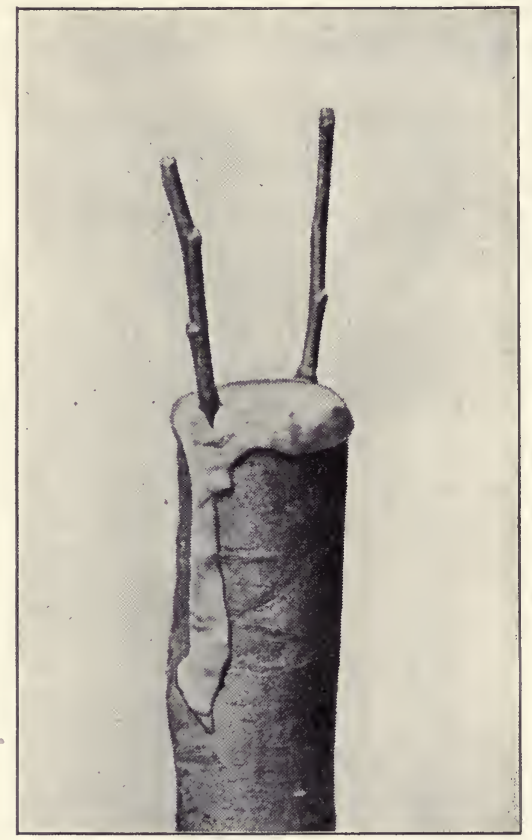

Fig. 32. Cleft graft, showing the stub after it has been waxed over are placed in each stub, according to its size.

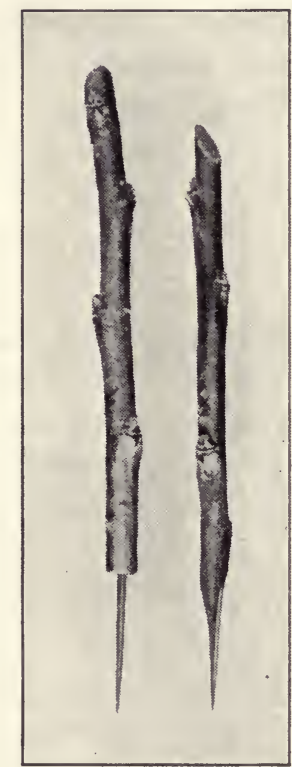

Fig. 33. Scion for bark and cleft grafting

The scions are cut very thin, with a shoulder on each side (Fig. 33). The cut should be at least one inch in length and not much more than one sixteenth of an inch in width. Why should this cut be so thin? Make a natural-size drawing of the scion, showing the shoulder. The scion should contain three or four well-developed buds.

1. Make a drawing, at least four inches in length and two and one-half inches in diameter, showing the stub and the location of each scion. In this method the scions are placed between the bark and the wood, and no cleft is made in the stub. A small penknife 
CLEFT GRAFTING AND BARK GRAFTING STUDENT'S NOTES AND REPORT 


\section{LABORATORY MANUAL OF HORTICULTURE}

is convenient in making an opening into which the scion can be inserted. Why are the scions placed between the bark and the wood instead of being placed in a cleft in the stock? After the scions have been placed in the stock, wax the whole surface over with grafting-wax, allowing the wax to extend over the edge of the stub about one fourth of an inch.

2. Make a drawing, four inches in length, showing the scions in place, after the whole surface has been waxed over with grafting-wax. Label all parts. When is this form of grafting used? Discuss. 


\section{CLEFT GRAFTING AND BARK GRAFTING}

STUDENT'S NOTES AND REPORT 


\section{EXERCISE XXXVI}

\section{THE STUDY OF BRIDGE GRAFTING}

Material. Stocks of the apple, three inches in diameter and twelve inches in length, scions from the same kind of trees.

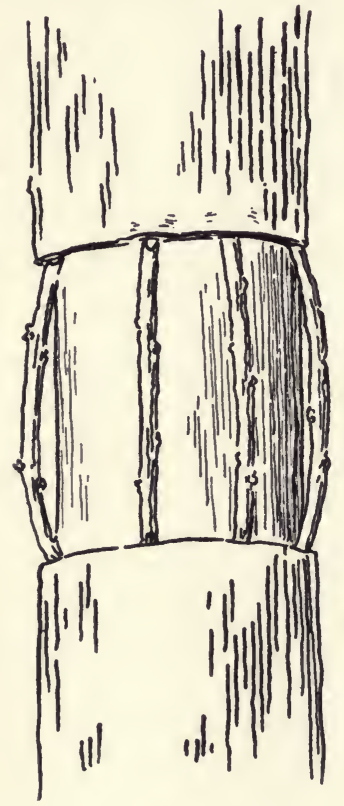

A

Fig. 34. Bridge grafting

$A$, stock, showing scions in position ready for waxing; $B$, scion, showing wedge at each end
Apparatus. Sharp knife, grafting-wax.

Bridge grafting is used to save girdled trees and for the healing over of wounds that have been made by cultivating-implements.

The wounded part is first thoroughly cleaned out (Fig. 34, $A$ ) and the bark cut back until it is smooth. The scions are cut wedge-shaped at both ends (Fig. 34, B) and varying in length according to the size of the wounded area, and are then pushed up firmly under the bark. They should be about an inch longer than the wound. From three to six scions are used, according to the size of the wound.

1. Make a drawing, two inches in diameter, showing the injury to the limb. Show by dotted lines the position of the cut which must be made in order to smooth up the edges. Why is it important to cut this bruised tissue back to firm bark? Discuss.

2. Make another drawing, the same size as the above, showing the scions set in place and the whole surface waxed over. Label and describe.

Make a drawing of a scion. How many buds are found? 
THE STUDY OF BRIDGE GRAFTING STUDENT'S NOTES AND REPORT 


\section{EXERCISE XXXVII}

\section{THE STUDY OF SIDE GRAFTING}

Material. Stocks of the apple or pear, one inch in diameter and twelve inches in length, scions from the same kind of trees.

Apparatus. Sharp, narrow chisel and sharp knife.

Side grafting is the method of grafting by inserting the scion into the stock without the cutting off of the stock (Fig. 35). It

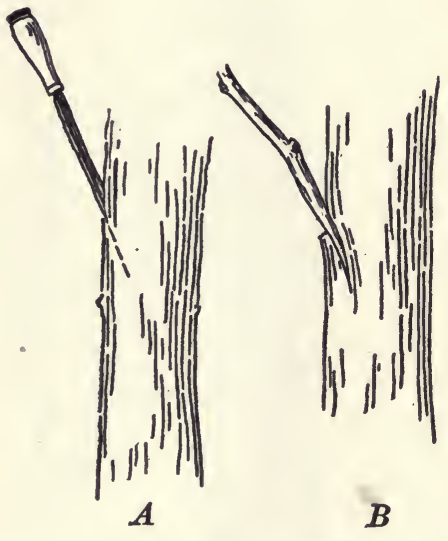

Fig. 35. Side grafting

$A$, stock, showing the ehisel in position; $B$, stock, showing the scion inserted

is often used to place a limb in a certain region where one is lacking, or for the grafting of some difficult subject, such as the mulberry or some of the beeches. The scion is placed in the side of the stock, set into an oblique incision made for the purpose. This cut can best be made by a thin-bladed chisel with a bent shank; however, any ordinary knife or chisel may be used. The angle at which the scion is placed is usually about 30 degrees. The incision should be made about an inch deep, and the scion should be cut wedgeshaped. As in bark grafting, the length of the wedge-shaped cut should correspond to the depth of the incision made in the stock.

1. Secure stocks about one inch in diameter and ordinary scions containing from two to four buds. Practice by making a number of these grafts.

Make a natural-size drawing of the stock, four inches in length, showing the chisel or the knife in position.

2. Make a drawing the same size as in 1 , showing the scion in position. How long is the wedge-shaped cut on the scion? Does the entire wedge of the scion fit into the incision made in the stock? Make a natural-size drawing of the scion. Discuss. 
THE STUDY OF SIDE GRAFTING STUDENT'S NOTES AND REPORT 


\section{EXERCISE XXXVIII}

\section{THE STUDY OF VENEER GRAFTING}

Material. Stocks of the apple or pear from one half to three fourths of an inch in diameter.

Apparatus. Grafting-cord or raffia, sharp knife or chisel.

This form of grafting is adapted to ornamentals and rare stocks which are usually grown in pots. In this method of grafting an

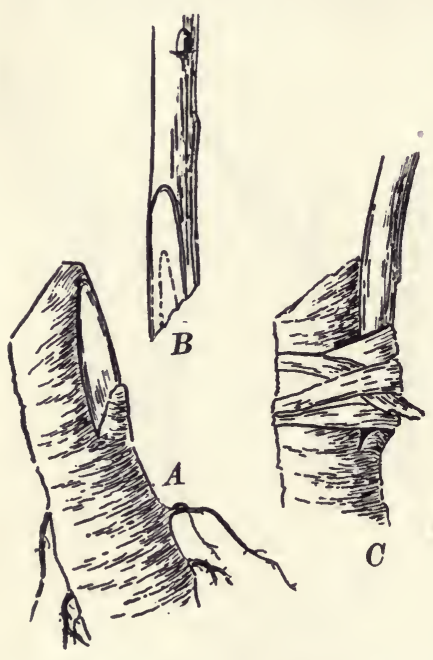

Fig. 36. Veneer grafting

$A$, stock, showing the cut; $B$, scion, showing the cut at the base; $C$, scion and stock united and tied incision is made into the wood, and all of the wounded surfaces are completely covered by the matching of the scion and the stock. No grafting-wax is used. This method is employed from November until March, and the scions are applied an inch or two above the surface of the soil. Both dormant and growing scions are used.

To make a veneer graft, an incision from one to one and one-half inches in length is made upon the stock, just through the bark, and the small piece of bark is removed by a downward-sloping cut at the base (Fig. 36). The base of the scion is cut off obliquely, and upon the longest side a portion of the bark is removed, corresponding to the part taken from the stock. The scion is then tied tightly to the stock.

1. Secure branches of the apple or the pear, from about one half to three fourths of an inch in diameter, and practice by making several of these grafts. Make all cuts clean and sharp. Make a natural-size drawing of the stock and the scion, at least three inches in length. Show the cut surfaces separately, and give the size of each.

2. Make a natural-size drawing, four inches in length, after the stock and the scion have been placed together and firmly tied. 
THE STUDY OF VENEER GRAFTLNG STUDENT'S NOTES AND REPORT 


\section{EXERCISE XXXIX}

\section{THE STUDY OF BORDEAUX MIXTURE}

Material. Copper sulphate, stone lime, hydrated lime.

Apparatus. Quart fruit jar, granite kettle, glass stirring-rod. Fungicides are chemicals that are used for the prevention or the killing of plant diseases. In some cases, where the fungus, or parasitic growth, is on the outside of the host, the external application of the fungicide will kill the disease. In other cases, where the disease is on the inside of the plant tissue, the host is covered with a fungicide, so that the spores, or reproductive bodies of the disease, are killed before they have a chance to enter the host plant.

There are several important fungicides. Bordeaux mixture is probably the best-known one, and it is made in different strengths for different purposes. It is a mixture of copper sulphate and lime, and the different strengths depend upon the amount of the chemicals used. The regular standard formulas for commercial spraying are as follows:

No. 1, Standard Bordeaux

Mixture

4 lb. copper sulphate

$4 \mathrm{lb}$. stone lime

50 gal. water
No. 2, Half-strength Bordeaux Mixture

2 lb. copper sulphate

2 lb. stone lime

50 gal. water

Laboratory formula for standard Bordeaux mixture. Dissolve one ounce of copper sulphate in two pints of water. Place one ounce of stone lime in a vessel, and slake in two pints of water and stir while slaking. Describe fully what takes place. Use these as stock solutions.

1. Now take one fourth of the copper sulphate solution and dilute it with the same quantity of cold water. Also take one fourth of the lime solution and dilute it with the same quantity of cold water. Pour the two diluted solutions together, fill a quart jar, and label. Describe what takes place and give the color of the solution. 
THE STUDY OF BORDEAUX MIXTURE

STUDENT'S NOTES AND REPORT 
2. Now repeat the same operation as in 1 , but use hot water to dilute each of the stock solutions. Place in a second glass jar, and label. Describe, and give your results.

3. Take one ounce of each of the stock solutions and pour into a glass jar. Dilute the mixture to eight ounces with cold water, and label.

4. Shake all three samples of Bordeaux and allow them to settle. After half an hour examine each sample carefully, note the differences, and record all data. Now permit the solutions to remain for three or four days and again agitate them and describe fully what takes place.

5. Make a second set of solutions as in Laboratory Formula 1, but instead of using stone lime use one and one-third ounces of hydrated lime. What is the difference between the hydrated lime and the stone lime? Describe. What result do you get from pouring water on the hydrated lime? Does this differ any from Laboratory Formula 1? If so, how and why? Describe the Bordeaux made from the hydrated lime. Does this differ any from that made from the stone lime? Describe.

Describe Bordeaux mixture. What, in your opinion, is the best sample? Why? After Bordeaux has stood for some time is it as good as when it is first made? Discuss. Is it advisable to keep a stock solution of Bordeaux? Why? Tell which is the most important chemical in the mixture and give the reason for your answer. Why is it necessary to make Bordeaux in either glass or wooden vessels? Tell the differences between the combined solutions and the separate ingredients. Why is it important that the diluted solutions be mixed rather than the concentrated? Discuss.

Laboratory formula for half-strength Bordeaux mixture. Now take one pint of the standard Bordeaux mixture and add one pint of water. What does this dilution of the mixture make? Describe the difference between the half-strength Bordeaux and the standard Bordeaux. When and on what plants is halfstrength Bordeaux mixture used?

Now take one pint of the standard Bordeaux made from hydrated lime, and add one pint of water. Does this differ from that made from the stone lime? If so, describe.

Problem 1. If it takes seven and one-half gallons of standard Bordeaux mixture to spray a fair-sized apple tree once, how 
THE STUDY OF BORDEAUX MIXTURE

STUDENT'S NOTES AND REPORT 


\section{LABORATORY MANUAL OF HORTICULTURE}

much will be required to spray fifty trees three times? If copper sulphate costs five and one-half cents a pound and lime a cent a pound, what will be the cost of the material?

Problem 2. I have a ten-acre apple orchard. There are fortynine trees to the acre. I wish to spray this orchard four times. How much Bordeaux mixture will be required, and what will be the cost of the chemicals?

\section{ReferenCES :}

Bulletin No. 135, Illinois Agricultural Experiment Station.

Farmers' Bulletin No. 243, United States Department of Agriculture, pp. 5-14.

Lodeman, "The Spraying of Plants," pp. 19-45. 
THE STUDY OF BORDEAUX MIXTURE

STUDENT'S NOTES AND REPORT 


\section{EXERCISE XL}

\section{THE STUDY OF LIME-SULPHUR}

Material. Stone lime, flowers of sulphur, commercial limesulphur.

Apparatus. One-gallon granite kettle, hydrometer, large glass cylinders, cooking burner.

It has been learned that lime-sulphur can be used as a fungicide and in some cases is superior to Bordeaux mixture for

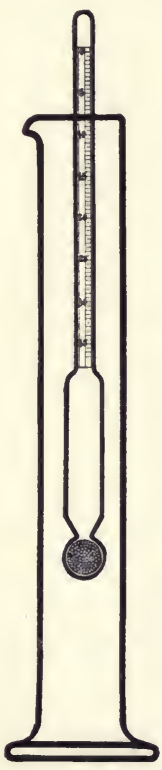

Fig. 37. Cylinder, showing hydrometer for testing the density of lime-sulphur solution the spraying of certain plants and the controlling of certain diseases. The point of difference between lime-sulphur as a fungicide and as an insecticide is the degree of dilution, or the strength of the solution. The strength can best be determined by the use of a hydrometer (Fig. 37), which tests the density of the solution.

There are several formulas from which the lime-sulphur is made. A good commercial formula to follow is

$$
\begin{aligned}
& \text { Stone lime . . . . . . } 40 \mathrm{lb} \text {. } \\
& \text { Flowers of sulphur . . . . } 80 \mathrm{lb} \text {. } \\
& \text { Water. . . . . . . } 50 \text { gal. }
\end{aligned}
$$

Laboratory formula. Weigh out four ounces of stone lime and eight ounces of flowers of sulphur. Place the lime in the granite vessel and slake with water, adding the water gradually and being careful not to smother the lime with too much water. Stir until the lime is thoroughly slaked and forms a uniform paste. Now add enough water to make a half gallon, after which place over the fire and boil. Now mix the flowers of sulphur to a thin paste, and add gradually to the lime when boiling, and stir constantly. Allow the mixture to boil for about an hour, stirring at frequent intervals. Keep the water in the 
THE STUDY OF LIME-SULPHUR

STUDENT'S NOTES AND REPORT

[139] 


\section{LABORATORY MANUAL OF HORTICULTURE}

vessel at a constant level by adding hot water from time to time. This level can be determined by measuring the depth of the liquid with a stick that has previously been notched.

As soon as this solution is cool enough, allow it to settle, pour off the liquid into a cylinder, and test with the hydrometer. Note the reading, and tabulate. Now dilute a portion of the solution with water according to the following scale, until it is the proper strength for a summer spray, and dilute another portion until it is the proper strength for a dormant spray.

\begin{tabular}{|c|c|c|c|}
\hline Degree, Baumé & SPECIFIC GRAvity & $\begin{array}{l}\text { DILUTION FOR } \\
\text { DORMANT SPRAY }\end{array}$ & $\begin{array}{l}\text { DILUTION FOR } \\
\text { SUMMER SPRAY }\end{array}$ \\
\hline 35 & 1.318 & 1 to 9 & 1 to 45 \\
\hline 34 & 1.306 & 1 to $8 \frac{8}{4}$ & 1 to 43 \\
\hline 33 & 1.294 & 1 to 8 & 1 to 41 \\
\hline 32 & 1.283 & 1 to $7 \frac{8}{4}$ & 1 to 40 \\
\hline 31 & 1.271 & 1 to $7 \frac{1}{2}$ & 1 to 38 \\
\hline 30 & 1.260 & 1 to 7 & 1 to 36 \\
\hline 29 & 1.250 & 1 to $6 \frac{3}{4}$ & 1 to 34 \\
\hline 28 & 1.239 & 1 to $6 \frac{1}{2}$ & 1 to 32 \\
\hline 27 & 1.228 & 1 to 6 & 1 to 31 \\
\hline 26 & 1.218 & 1 to $5 \frac{3}{4}$ & 1 to 29 \\
\hline 25 & 1.208 & 1 to $5 \frac{1}{2}$ & 1 to 28 \\
\hline 24 & 1.198 & 1 to $5 \frac{1}{4}$ & 1 to 26 \\
\hline 23 & 1.188 & 1 to $4 \frac{3}{4}$ & 1 to 24 \\
\hline 22 & 1.178 & 1 to $4 \frac{1}{2}$ & 1 to 23 \\
\hline 21 & 1.169 & 1 to $4 \frac{1}{4}$ & 1 to 21 \\
\hline 20 & 1.160 & 1 to 4 & 1 to 20 \\
\hline 19 & 1.150 & 1 to $3 \frac{1}{2}$ & 1 to 18 \\
\hline 18 & 1.141 & 1 to $3 \frac{1}{4}$ & 1 to 17 \\
\hline 17 & 1.132 & 1 to 3 & 1 to 16 \\
\hline 16 & 1.124 & 1 to $2 \frac{3}{4}$ & 1 to 15 \\
\hline 15 & 1.115 & 1 to $2 \frac{1}{2}$ & 1 to 14 \\
\hline
\end{tabular}

The above table is for diluting the concentrated lime-and-sulphur solution for the dormant as well as for the summer sprays. The dilution for the summer sprays is usually from thirty-five to forty-five gallons of water when the Baumé test is $32^{\circ}$ or $33^{\circ}$. Now figure out from this table the degree of the dilution of your sample made in the laboratory.

Example 1. The concentrated lime-sulphur solution, test $35^{\circ}$ Baumé, by the table has a specific gravity of 1.318. If it is desired to spray trees with lime-sulphur at $20^{\circ}$ Baumé, which has a specific gravity of 1.160 , calculate the number of dilutions required as follows: the decimal of concentration of the 
THE STUDY OF LIME-SULPHUR

STUDENT'S NOTES AND REPORT 
Baumé $35^{\circ}$ is .318 ; this, divided by the decimal for Baumé $20^{\circ}$, which is .160 , will give 19.8 , or the number of dilutions required, this result being obtained by adding 19.8 volumes of water to 1 volume of the concentrated lime and sulphur. This rule is based upon the general fact that the density of a solution heavier than water varies inversely with the number of dilutions.

When the density of the lime-sulphur solution or the homemade wash has been first determined by the use of a hydrometer, sprays of any desired density may be calculated by using the table. The rule for determining the number of dilutions is as follows: divide the decimal of the concentrate by the decimal of the spray desired; the quotient will be the number of dilutions.

$$
\begin{aligned}
\frac{\text { Decimal of the concentrate }}{\text { Decimal of the spray desired }} & =\text { the number of dilutions } \\
\frac{.318}{.160} & =19.8
\end{aligned}
$$

Example 2. Assuming that the decimal of the concentrate is known and that this concentrate is diluted by a certain number of volumes of water, what is the decimal of the spray? Taking the same example as in Ex. 1, we have the decimal of the concentrate, .318, and the number of dilutions, 19.8. Dividing .318 by 19.8 equals .160 , which is the decimal of the spray and corresponds to $20^{\circ}$ Baumé. Now figure out the degree of dilution for each sample you make in the laboratory.

$$
\begin{aligned}
\frac{\text { Decimal of the concentrate }}{\text { Number of dilutions }} & =\text { decimal of the spray } \\
\frac{.318}{19.8} & =.160
\end{aligned}
$$

Secure some concentrated lime-sulphur solution. How does this differ in color and looks from the home-made lime-sulphur solution? Test each of the solutions with the hydrometer. Note the reading in each case. What amount of water was necessary to bring both of the solutions to the same reading? How do you account for the difference, if any? Discuss fully.

\section{REFERENCES :}

Bulletin No. 288, Cornell Agricultural Experiment Station.

Bulletin No. 289, Cornell Agricultural Experiment Station.

Circular No. 10, Michigan Agricultural Experiment Station.

Bulletin No. 330, New York Agricultural Experiment Station. 
THE STUDY OF LIME-SULPHUR

STUDENT'S NOTES AND REPORT

[143] 


\section{EXERCISE XLI}

\section{THE STUDY OF SELF-BOILED LIME-SULPHUR}

Material. Stone lime, flowers of sulphur.

Apparatus. Granite kettle, stirring-rod.

Self-boiled lime-sulphur differs from the lime-sulphur wash in Exercise XL chiefly in that there is no artificial heat applied and all of the cooking that the solution undergoes is done by the heat generated by the stone lime in slaking. This is used only as a summer spray, and is proving very satisfactory for use on the peach against the scab and brown rot. The formula that is most often used is

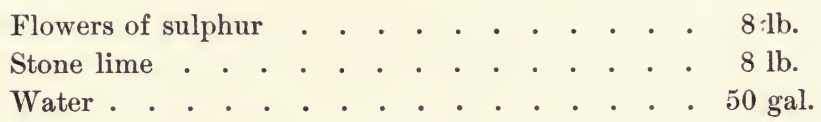

Laboratory formula. Weigh out two and one-half ounces of the flowers of sulphur and two and one-half ounces of stone lime. Place the lime and the sulphur in a granite vessel and add enough cold water to slake the lime, stirring constantly to prevent burning. Cover the granite kettle, so as to retain as much of the heat as possible. Watch the mixture closely, and as soon as an orange-colored liquid begins to gather on the surface add enough more water to make a gallon. Do not use hot water or allow the mixture to stand after the lime is slaked or before dilution. In this spray we do not want soluble sulphides to form, because these will injure the foliage as well as the fruit. How does this solution differ from the one in Exercise XL? Describe the color of each solution and note any differences. Why should cold water be used instead of hot water? Why is the prevention of the formation of soluble sulphides especially important? Discuss.

\section{REFERENCE :}

Special Bulletin No. 61, Michigan Agricultural Experiment Station. 
THE STUDY OF SELF-BOILED LIME-SULPHUR

STUDENT'S NOTES AND REPORT 


\section{EXERCISE XLII}

\section{THE STUDY OF AMMONIACAL SOLUTION OF COPPER CARBONATE}

Material. Copper sulphate, carbonate of soda, ammonia. Apparatus. Quart glass jar, stirring-rod, granite kettle.

To make this fungicide it is necessary first to make the copper carbonate. The common formula for copper carbonate is

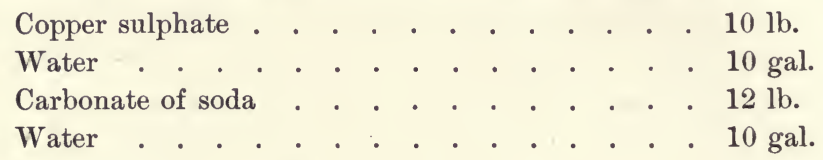

Laboratory formula. Weigh out two ounces of copper sulphate and dissolve in one pint of water, and in a separate vessel dissolve two ounces of carbonate of soda in one pint of water. When cool, mix the two solutions slowly, stirring well. Allow the solution to stand twelve hours to settle, after which pour off the liquid. Add one quart of water and stir a second time, again allowing the solution to stand for twelve hours. Repeat this operation several times and then filter off the residue. The blue powder thus obtained is copper carbonate. Describe fully the operation and explain each step. What is the difference between the finished product and the copper sulphate? Write out the chemical formula and give the resulting product.

The common formula for ammoniacal solution of copper carbonate is

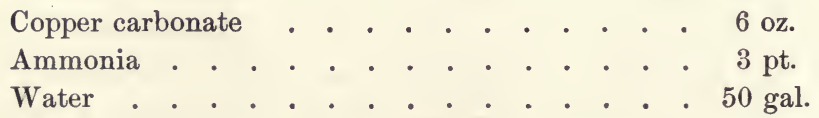

Laboratory formula. Weigh out one fourth of an ounce of the copper carbonate just prepared and dissolve this in one eighth of a pint of ammonia. When thoroughly dissolved, add enough water to make two gallons. What is the function of the ammonia? Where is this fungicide used? How does it differ in this respect from Bordeaux mixture? Give the chemical formula of copper carbonate when mixed with the ammonia. 
AMMONIACAL SOLUTION OF COPPER CARBONATE STUDENT'S NOTES AND REPORT 


\section{EXERCISE XLIII}

\section{THE STUDY OF PARIS GREEN AND ARSENATE OF LEAD}

Material. Paris green, powdered arsenate of lead, paste arsenate of lead.

Apparatus. Quart glass jars, stirring-rod.

Insecticides differ from fungicides in that they are chemicals used for the destruction of insects that prey upon cultivated plants. There are two kinds of insecticides: namely, stomach poisons, or insecticides that are eaten by the insects and kill by being taken into the stomach; and contact insecticides, or those which are sprayed on the insects and kill by coming in contact with their bodies.

\section{Paris Green}

Paris green, one of our important insecticides, is an acetoarsenite of copper, and Ehrmann has given the composition of pure Paris green as follows:

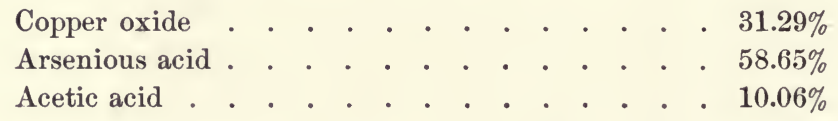

However, most samples show some variation from the above. The free arsenic in the Paris green is dangerous to foliage, and when Paris green is used alone, lime should be added to avoid burning the leaves.

The usual formula for spraying is

Paris green . . . . . . . . $1 \mathrm{lb}$.

Water . . . . . . . . 100 to 300 gal.

Laboratory formula. Weigh out one fourth of an ounce of Paris green and place it in a quart fruit jar of water. Study carefully the action of the poison when placed in the water. Describe what takes place. Now with a stirring-rod vigorously agitate the water. Does it mix with the water? If not, why? Describe. Is Paris green in water a solution or a mixture? 
PARIS GREEN AND ARSENATE OF LEAD

STUDENT'S NOTES AND REPORT

[149] 


\section{Arsenate of Lead}

Arsenate of lead is another of our important insecticides and to-day probably ranks first. It can be purchased in two forms as a powder or as a paste. The paste form is the most widely used. The usual formula for arsenate of lead is from two to three pounds to fifty gallons of water, but the proportion varies with the crop to be sprayed.

Laboratory formula. Weigh out one-half ounce each of the powdered and the paste form of arsenate of lead, and dissolve each in a separate quart glass fruit jar of water. Study carefully. what takes place.. Now place all three of the jars containing the insecticides where the light will pass through them. Stir each vigorously for a minute and note the results. Watch the solutions for fifteen minutes, noting what takes place in each case. Are the insecticides completely dissolved, forming a chemical union, or are they held in suspension, with only a slight chemical action taking place? Discuss. Note accurately the length of time required for each solution to settle. Discuss in detail why it is absolutely necessary to have the spray mixture thoroughly agitated during the whole time of spraying. 
PARIS GREEN AND ARSENATE OF LEAD

STUDENT'S NOTES AND REPORT 


\section{EXERCISE XLIV}

\section{THE STUDY OF KEROSENE EMULSION}

Material. Laundry soap, kerosene.

Apparatus. Granite kettle, cooking-burner, stirring-rod.

This insecticide is used for many scale insects, and also for some other of the sucking insects, such as the plant lice, etc. The emulsion is usually made in the form of a stock solution and diluted to the required strength when needed. The regular formula is

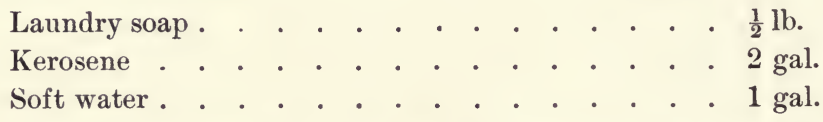

Laboratory formula. Weigh out one ounce of laundry soap, cut into small pieces, and dissolve it in one pint of water. Allow this solution to boil, remove it from the fire, and add one quart of kerosene. Stir the mixture violently until it becomes a creamy mass that will not separate. This usually requires from five to ten minutes. The emulsion is now finished. Describe kerosene enulsion. Name several kinds of insects upon which it is used. What is an emulsion?

For use, dilute one part of the emulsion with eight or ten parts of water for hard-bodied insects and with fifteen or twenty parts of water for soft-bodied insects. Why is it detrimental to use the kerosene alone, and what is the destructive principle in the emulsion? 
THE STUDY OF KEROSENE EMULSION

STUDENT'S NOTES AND REPORT 


\section{EXERCISE XLV}

\section{A STUDY OF THE APPLE}

(Underscore or star the terms that apply to the variety of fruit being studied)

VARIETY

DATE

GrouP

SYNONYMS

\begin{tabular}{|c|c|c|c|}
\hline Size & Large & Compressed & Stamens \\
\hline Large & Medium & Raised & Basal \\
\hline Medium & Small & Rough & Marginal \\
\hline Small & CuLYY LOREg & Submerged & Medial \\
\hline FORM & $\begin{array}{l}\text { CALYX LOBES } \\
\text { Acuminate }\end{array}$ & Gray & Carpels \\
\hline Conical & $\begin{array}{l}\text { Acuminate } \\
\text { Acute }\end{array}$ & Red & Cordate \\
\hline Irregular & Obtuse & $\begin{array}{l}\text { Russet } \\
\text { White }\end{array}$ & Emarginate \\
\hline Oblate & Long & White & Ovate \\
\hline Oblong & Medium & CORE & Round \\
\hline Oblique & Short & Abaxile & Tufted \\
\hline Ovate & Narrow & Axile & SEED \\
\hline Ribbed & Wide & Large & Acuminate \\
\hline Roundish & Separated at base & Medium & Acute \\
\hline Symmetrical & & Small & Flat \\
\hline Stem & BASIN & Closed & Large \\
\hline Long & & Open & Long \\
\hline Medium & $\begin{array}{l}\text { Corrugated } \\
\text { Furrowed }\end{array}$ & $\begin{array}{l}\text { Distant } \\
\text { Median }\end{array}$ & Medium \\
\hline $\begin{array}{l}\text { Short } \\
\text { Slender }\end{array}$ & Obtuse & Sessile & Narrow \\
\hline $\begin{array}{l}\text { Slender } \\
\text { Thick }\end{array}$ & Symmetrical & Core Line & $\begin{array}{l}\text { Obtuse } \\
\text { Plump }\end{array}$ \\
\hline Cavity & $\begin{array}{l}\text { Deep } \\
\text { Medium }\end{array}$ & Clasping. & Small \\
\hline Acuminate & Shallow & Meeting & Tufted \\
\hline Acute & Narrow & Calyx Tube & Wide \\
\hline Lipped & Wide & Conical & Flayor \\
\hline Obtuse & SkIN & Funnel-shaped & Aromatic \\
\hline Russeted & Dull & Urn-shaped & Flat \\
\hline Symmetrical & Glossy & Long & Sour \\
\hline Narrow & Rough & Short & Sprightly \\
\hline Wide & Russet & Narrow & Sub-acid \\
\hline Deep & Smooth & Wide & QuaLity \\
\hline Medium & Tender & Flesh & Best \\
\hline Shallow & Thin & Color .... & Good \\
\hline COLOR & Tough & Texture & Very good \\
\hline Ground ................. & Waxen & Coarse & $\begin{array}{l}\text { Medium } \\
\text { Poor }\end{array}$ \\
\hline $\begin{array}{l}\text { Overlying } \\
\text { Blushed }\end{array}$ & Dots & Crisp & Very poor \\
\hline $\begin{array}{l}\text { Blushed } \\
\text { Mottled }\end{array}$ & Areolar & Dry & MARKET \\
\hline Striped & Elongated & Fine & Distant \\
\hline Polish....................... & Stellate & $\begin{array}{l}\text { Firm } \\
\text { Juicy }\end{array}$ & Local \\
\hline Prevailing effect.. & $\begin{array}{l}\text { Few } \\
\text { Many }\end{array}$ & $\begin{array}{l}\text { Juicy } \\
\text { Medium }\end{array}$ & UsE \\
\hline CaLYX 。 & Large & Sweet & Cooking \\
\hline Closed & Medium & Tender & Dessert \\
\hline Open & Small & 'Tough & Market \\
\hline
\end{tabular}




\section{A STUDY OF THE APPLE}

SEASON

LOCAI.ITY

Productiveness

Geveral Appearance.

Desirability

History

REMARKS

Draw a Iongitudinal section of the fruit. 


\section{EXERCISE XLVI}

\section{A STUDY OF THE APPLE}

(Underscore or star the terms that apply to the variety of fruit being studied)

VARIETY

DATE

Group

SyNoNyMs

\begin{tabular}{|c|c|c|c|}
\hline Size & Large & Compressed & Stainens \\
\hline Large & Medium & Raised & Basal \\
\hline Medium & Small & Rough & Marginal \\
\hline Small & CALYX Lobes & Submerged & Medial \\
\hline ForM & Acuminate & Gray & Carpels \\
\hline Conical & Acute & Red & Cordate \\
\hline Irregular & Obtuse & $\begin{array}{l}\text { Russet } \\
\text { White }\end{array}$ & Emarginate \\
\hline Oblate & Long & W nite & Ovate \\
\hline Oblong & Medium & CORE & Round \\
\hline Oblique & Short & Abaxile & Tufted \\
\hline Ovate & Narrow & Axile & SeED \\
\hline Ribbed & Wide & Large & Acuminate \\
\hline Roundish & Separated at base & Medium & Acute \\
\hline Symmetrical & BASIN & Small & Flat \\
\hline SteM & Abrupt & $\begin{array}{l}\text { Closed } \\
\text { Open }\end{array}$ & Large \\
\hline Long & Corrugated & $\begin{array}{l}\text { Upen } \\
\text { Distant }\end{array}$ & Long \\
\hline Medium & Furrowed & Median & Medium \\
\hline $\begin{array}{l}\text { Short } \\
\text { Slender }\end{array}$ & Obtuse & Sessile & $\begin{array}{l}\text { Narrow } \\
\text { Obtuse }\end{array}$ \\
\hline Thick & $\begin{array}{l}\text { Symmetrical } \\
\text { Deep }\end{array}$ & Core Line & Plump \\
\hline Cavity & $\begin{array}{l}\text { Deep } \\
\text { Medium }\end{array}$ & Clasping & Small \\
\hline $\begin{array}{l}\text { Acuminate } \\
\text { Acute }\end{array}$ & Shallow & Meeting & 'Tufted \\
\hline $\begin{array}{l}\text { Acute } \\
\text { Lipped }\end{array}$ & Narrow & Calyx Tube & Wide \\
\hline Lipped & Wide & Conical & FlavOR \\
\hline $\begin{array}{l}\text { Obtuse } \\
\text { Russeted }\end{array}$ & Skin & Funnel-shaped & Aromatic \\
\hline $\begin{array}{l}\text { Russeted } \\
\text { Symmetrical }\end{array}$ & Dull & Urn-shaped & $\begin{array}{l}\text { Flat } \\
\text { Sour }\end{array}$ \\
\hline $\begin{array}{l}\text { symmetrical } \\
\text { Narrow }\end{array}$ & Glossy & Long & Sprightly \\
\hline Wide & $\begin{array}{l}\text { Rough } \\
\text { Russet }\end{array}$ & $\begin{array}{l}\text { Snort } \\
\text { Narrow }\end{array}$ & Sub-acid \\
\hline Deep & Smooth & Wide & Quality \\
\hline Medium & Tender & Flesh & Best \\
\hline Shallow & Thin & Color ...... & Good \\
\hline Color & Tough & Texture & $\begin{array}{l}\text { Very good } \\
\text { Medium }\end{array}$ \\
\hline Ground...... & Waxen & Coarse & $\begin{array}{l}\text { Medium } \\
\text { Poor }\end{array}$ \\
\hline Overlying & Dots & Crisp & $\begin{array}{l}\text { Poor } \\
\text { Very poor }\end{array}$ \\
\hline $\begin{array}{l}\text { Blushed } \\
\text { Mottled }\end{array}$ & Areolar & Dry & MARKET \\
\hline Striped & Elongated & Fine & Distant \\
\hline Polish ....................... & Stellate & $\begin{array}{l}\text { Firm } \\
\text { Juicy }\end{array}$ & Local \\
\hline Prevailing effect.. & $\begin{array}{l}\text { Few } \\
\text { Many }\end{array}$ & $\begin{array}{l}\text { Juicy } \\
\text { Medium }\end{array}$ & UsE \\
\hline CALYX & Large & Sweet & Cooking \\
\hline Closed & Medium & Tender & Dessert \\
\hline Open & Small & Tough & Market \\
\hline
\end{tabular}




\section{A STUDY OF THE APPLE}

SEASON

LOCALITY

Productiveness

General Appearance.

DESIRABILITY

HistoRY

REMARKS

Draw a longitudinal section of the fruit. 


\section{EXERCISE XLVII}

\section{A STUDY OF THE APPLE}

(Underscore or star the terms that apply to the variety of fruit being studied)

VARIETY

DATE

Grou P

SYNONYMS

\begin{tabular}{|c|c|c|c|}
\hline SizE & Large & Compressed & Stamens \\
\hline Large & Medium & Raised & Basal \\
\hline Medium & Small & Rough & Marginal \\
\hline Small & Cahyx Lobes & Submerged & Medial \\
\hline Form & $\begin{array}{c}\text { CALYX LOBES } \\
\text { Acuminate }\end{array}$ & Gray & Carpels \\
\hline Conical & $\begin{array}{l}\text { Acummate } \\
\text { Acute }\end{array}$ & Red & Cordate \\
\hline Irregular & Obtuse & Russet & Emarginate \\
\hline Oblate & Long & White & Ovate \\
\hline Oblong & Medium & Core & Round \\
\hline Oblique & Short & Abaxile & Tufted \\
\hline Ovate & Narrow & Axile & SEed \\
\hline Ribbed & Wide & Large & Acuminate \\
\hline Roundish & Separated at base & Medium & Acute \\
\hline Symmetrical & BASIN & $\begin{array}{l}\text { Small } \\
\text { Closed }\end{array}$ & Flat \\
\hline SteM & Abrupt & $\begin{array}{l}\text { Closed } \\
\text { Open }\end{array}$ & Large \\
\hline Long & Corrugated & $\begin{array}{l}\text { Open } \\
\text { Distant }\end{array}$ & Long \\
\hline Medium & Furrowed & Median & Medium \\
\hline Short & Obtuse & Sessile & Narrow \\
\hline Slender & Symmetrical & Core Line & Obtuse \\
\hline Thick & Deep & Clasping & Plump \\
\hline Cavity & Medium & Meeting & 'Tufted \\
\hline $\begin{array}{l}\text { Acuminate } \\
\text { Acute }\end{array}$ & $\begin{array}{l}\text { Shallow } \\
\text { Narrow }\end{array}$ & Calyx Tube & Wide \\
\hline $\begin{array}{l}\text { Acute } \\
\text { Lipped }\end{array}$ & Wide & Conical & Flavor \\
\hline Obtuse & SkIN & Funnel-shaped & Aromatic \\
\hline Russeted & Dull & Urn-shaped & Flat \\
\hline Symmetrical & Glossy & Long & Sour \\
\hline Narrow & Rough & Short & Sprightly \\
\hline Wide & Russet & Narrow & Sub-acid \\
\hline Deep & Smooth & Wide & QUALity \\
\hline Medium & Tender & Flesh & Best \\
\hline Shallow & Thin & Color..... & Good \\
\hline Color & Tough & TeXture & Very good \\
\hline Ground............... & Waxen & $\begin{array}{l}\text { 1EXTuRe } \\
\text { Coarse }\end{array}$ & Medium \\
\hline Overlying & Dots & $\begin{array}{l}\text { Crisp } \\
\text { Crisp }\end{array}$ & $\begin{array}{l}\text { Poor } \\
\text { Very poor }\end{array}$ \\
\hline Blushed & Areolar & Dry & Very poor \\
\hline $\begin{array}{l}\text { Mottled } \\
\text { Striped }\end{array}$ & Elongated & Fine & MARKET \\
\hline $\begin{array}{c}\text { Striped } \\
\text { Polish................. }\end{array}$ & Stellate & Firm & Distant \\
\hline Prevailing effect... & Few & Juicy & Local \\
\hline CaLYX & Many & Medium & UsE \\
\hline Closed & $\begin{array}{l}\text { Large } \\
\text { Medium }\end{array}$ & Sweet & Cooking \\
\hline Open & $\begin{array}{l}\text { Medium } \\
\text { Small }\end{array}$ & $\begin{array}{l}\text { Tender } \\
\text { Tough }\end{array}$ & $\begin{array}{l}\text { Dessert } \\
\text { Market }\end{array}$ \\
\hline
\end{tabular}




\section{A STUDY OF THE APPLE}

\section{Season}

LOCALITY

Productiveness

General Appearance

DesIRA BILITY

HISTORY

REMARKS

Draw a longitudinal section of the fruit. 


\section{EXERCISE XLVIII}

\section{A STUDY OF THE APPLE}

(Underscore or star the terms that apply to the variety of fruit being studied)

VARIETY

DATE

Group

SYNONYMS

\begin{tabular}{|c|c|c|c|}
\hline Size & Large & Compressed & Stamens \\
\hline Large & Medium & Raised & Basal \\
\hline Medium & Small & Rough & Marginal \\
\hline Small & CALYX LOBES & Submerged & Medial \\
\hline ForM & Acuminate & Gray & Carpels \\
\hline Conical & $\begin{array}{l}\text { Acute } \\
\text { Acute }\end{array}$ & Red & Cordate \\
\hline Irregular & Obtuse & $\begin{array}{l}\text { Russet } \\
\text { White }\end{array}$ & Emarginate \\
\hline $\begin{array}{l}\text { Oblate } \\
\text { Oblong }\end{array}$ & Long & Winte & Ovate \\
\hline $\begin{array}{l}\text { Oblong } \\
\text { Oblique }\end{array}$ & Medium & CORE & Round \\
\hline $\begin{array}{l}\text { Oblique } \\
\text { Ovate. }\end{array}$ & Short & $\begin{array}{l}\text { Abaxile } \\
\text { Axile }\end{array}$ & Tufted \\
\hline $\begin{array}{l}\text { Ovate } \\
\text { Ribbed }\end{array}$ & Narrow & $\begin{array}{l}\text { Axile } \\
\text { Larce }\end{array}$ & SEED \\
\hline $\begin{array}{l}\text { Ribbed } \\
\text { Roundish }\end{array}$ & Wide & Large & Acuminate \\
\hline $\begin{array}{l}\text { Roundish } \\
\text { Symmetrical }\end{array}$ & Separated at base & $\begin{array}{l}\text { Medium } \\
\text { Small }\end{array}$ & Acute \\
\hline Stem & Basin & Closed & $\begin{array}{l}\text { Flat } \\
\text { Large }\end{array}$ \\
\hline Long & Abrupt & Open & $\begin{array}{l}\text { Large } \\
\text { Long }\end{array}$ \\
\hline Medium & Corrugated & Distant & Medium \\
\hline Short & Furrowed & Median & Narrow \\
\hline Slender & $\begin{array}{l}\text { Obtuse } \\
\text { Symmetrical }\end{array}$ & Sessile & Obtuse \\
\hline Thick & $\begin{array}{l}\text { Symmetrical } \\
\text { Deep }\end{array}$ & Core Line & Plump \\
\hline Cavity & Medium & Clasping & Small \\
\hline $\begin{array}{l}\text { Acuminate } \\
\text { Acute }\end{array}$ & $\begin{array}{l}\text { Shallow } \\
\text { Narrow }\end{array}$ & CuYY Tube & $\begin{array}{l}\text { Turted } \\
\text { wide }\end{array}$ \\
\hline $\begin{array}{l}\text { Acute } \\
\text { Lipped }\end{array}$ & Wide & Conical & Flayor \\
\hline Obtuse & SkIN & Funnel-shaped & Aromatic \\
\hline Russeted & Dull & Urn-shaped & Flat \\
\hline Symmetrical & Glossy & Long & Sour \\
\hline Narrow & Rough & Short & Sprightly \\
\hline Wide & Russet & Narrow & Sub-acid \\
\hline Deep & Smooth & Wide & Quality \\
\hline Medium & Tender & F Lesh & Best \\
\hline Shallow & Thin & Color ........... & Good \\
\hline Color & Tough & Texture & Very good \\
\hline Ground................. & Waxen & Coarse & $\begin{array}{l}\text { Medium } \\
\text { Poor }\end{array}$ \\
\hline $\begin{array}{c}\text { Overlying } \\
\text { Blushed }\end{array}$ & Dотs & Crisp & Very poor \\
\hline $\begin{array}{l}\text { Blushed } \\
\text { Mottled }\end{array}$ & Areolar & Dry & MARKET \\
\hline Striped & Elongated & Fine & Distant \\
\hline Polish ................... & $\begin{array}{l}\text { Stellate } \\
\text { Few }\end{array}$ & $\begin{array}{l}\text { Firn } \\
\text { Juicy }\end{array}$ & Local \\
\hline Prevailing effect.. & Many & Medium & UsE \\
\hline CALYX & Large & Sweet & Cooking \\
\hline Closed & Medium & Tender & Dessert \\
\hline Open & Small & Tough & Market \\
\hline
\end{tabular}




\section{A STUDY OF THE APPLE}

Seasox

LOCALITY

Productiveness

Geveral Appearance

DESIRABILITY

HISTORY

REMARKS

Draw a longitudinal section of the fruit. 


\section{EXERCISE XLIX}

\section{A STUDY OF THE APPLE}

(Underscore or star the terms that apply to the variety of fruit being studied)

VARIETY

DATE

\section{Group}

SyNoNyMs

\begin{tabular}{|c|c|c|c|}
\hline SIZE & Large & Compressed & Stamexs \\
\hline Large & Medium & Raised & Basal \\
\hline Medium & Small & Rough & Marginal \\
\hline Small & CALyX LoBes & Submerged & Medial \\
\hline FORM & $\begin{array}{c}\text { CALYX LOBES } \\
\text { Acuminate }\end{array}$ & Gray & Carpels \\
\hline Conical & $\begin{array}{l}\text { Acuminate } \\
\text { Acute }\end{array}$ & Red & Cordate \\
\hline Irregular & Obtuse & Russet & Emarginate \\
\hline Oblate & Long & White & Ovate \\
\hline Oblong & Medium & Core & Round \\
\hline Oblique & Short & Abaxile & Tufted \\
\hline Ovate & Narrow & Axile & SEED \\
\hline Ribbed & Wide & Large & Acuminate \\
\hline Roundish & Separated at base & Medium & Acute \\
\hline Symmetrical & & Small & Flat \\
\hline STEM & BASIN & Closed & Large \\
\hline Long & Abrupt & Open & Long \\
\hline Medium & Corrugated & Distant & Medium. \\
\hline Short & Furrowed & Median & Narrow \\
\hline Slender & Obtuse & Sessile & Obtuse \\
\hline Thick & $\begin{array}{l}\text { symmetrical } \\
\text { Deep }\end{array}$ & Core Line & Plump \\
\hline Cavity & Medium & Clasping & Small \\
\hline Acuminate & Shallow & Meeting & Tufted \\
\hline Acute & Narrow & Calyx Tube & Wide \\
\hline Lipped & Wide & Conical & Flavor \\
\hline Obtuse & SkIN & Funnel-shaped & Aromatic \\
\hline Russeted & Dull & Urn-shaped & Flat \\
\hline Symmetrical & Glossy & Long & Sour \\
\hline Narrow & Rough & Short & Sprightly \\
\hline Wide & Russet & Narrow & Sub-acid \\
\hline Deep & Smooth & Wide & QUALITY \\
\hline Medium & Tender & Flesh & Best \\
\hline Shallow & Thin & Color.... & Good \\
\hline Color & Tough & & Very good \\
\hline Ground................ & Waxen & TeXtuRe & Medium \\
\hline Overlying & Doms & Coarse & Poor \\
\hline Blushed & & Crisp & Very poor \\
\hline Mottled & Areolar & Dry & MARKeT \\
\hline Striped & & Fine & Distant \\
\hline Polish.................. & $\begin{array}{l}\text { Stellate } \\
\text { Few }\end{array}$ & $\begin{array}{l}\text { Firm } \\
\text { Juicy }\end{array}$ & Local \\
\hline Prevailing effect.. & Many & Medium & UsE \\
\hline CALYX & Large & Sweet & Cooking \\
\hline Closed & Medium & Tender & Dessert \\
\hline Open & Small & Tough & Market \\
\hline
\end{tabular}


A STUDY OF THE APPLE

Season

LOCALITY

Productivenfiss

General Appearance

Desirability

HISTORY

RFMARKS

Draw a longitudinal section of the fruit. 


\section{EXERCISE L}

\section{A STUDY OF THE APPLE}

(Underscore or star the terms that apply to the variety of fruit being studied)

VARIETY

DATE

Grove

SYNONYMS

\begin{tabular}{|c|c|c|c|}
\hline SIZE & Large & Compressed & Stamens \\
\hline $\begin{array}{l}\text { Large } \\
\text { Medium }\end{array}$ & $\begin{array}{l}\text { Medium } \\
\text { Small }\end{array}$ & $\begin{array}{l}\text { Raised } \\
\text { Rough }\end{array}$ & Basal \\
\hline $\begin{array}{l}\text { Medium } \\
\text { Small }\end{array}$ & Small & $\begin{array}{l}\text { Rough } \\
\text { Submerged }\end{array}$ & $\begin{array}{l}\text { Marginal } \\
\text { Medial }\end{array}$ \\
\hline ForM & $\begin{array}{c}\text { CALYX LoBES } \\
\text { Acuminate }\end{array}$ & Gray & CARPELS \\
\hline Conical & $\begin{array}{l}\text { Acuminate } \\
\text { Acute }\end{array}$ & Red & Cordate \\
\hline Irregular & Obtuse & $\begin{array}{l}\text { Russet } \\
\text { White }\end{array}$ & Emarginate \\
\hline Oblate & Long & Core & Ovate \\
\hline Oblong & Medium & $\begin{array}{l}\text { CORE } \\
\text { Abaxile }\end{array}$ & Round \\
\hline $\begin{array}{l}\text { Oblique } \\
\text { Ovate }\end{array}$ & $\begin{array}{l}\text { Short } \\
\text { Narrow }\end{array}$ & $\begin{array}{l}\text { Abaxile } \\
\text { Axile }\end{array}$ & Tufted \\
\hline $\begin{array}{l}\text { Ovate } \\
\text { Ribbed }\end{array}$ & $\begin{array}{l}\text { Narrow } \\
\text { Wide }\end{array}$ & $\begin{array}{l}\text { Axle } \\
\text { Large }\end{array}$ & SEED \\
\hline $\begin{array}{l}\text { Ribbed } \\
\text { Roundish }\end{array}$ & $\begin{array}{l}\text { Wide } \\
\text { Separated at base }\end{array}$ & Medium & Acuminate \\
\hline Symmetrical & & Small & $\begin{array}{l}\text { Acute } \\
\text { Flat }\end{array}$ \\
\hline SteM & BASIN & Closed & Large \\
\hline Long & Abrupt & Open & Long \\
\hline Medium & $\begin{array}{l}\text { Corrugated } \\
\text { Furrowed }\end{array}$ & $\begin{array}{l}\text { Distant } \\
\text { Median }\end{array}$ & Medium \\
\hline $\begin{array}{l}\text { Short } \\
\text { Slender }\end{array}$ & Obtuse & $\begin{array}{l}\text { Median } \\
\text { Sessile }\end{array}$ & Narrow \\
\hline $\begin{array}{l}\text { Slender } \\
\text { Thick }\end{array}$ & $\begin{array}{l}\text { Symmetrical } \\
\text { Deep }\end{array}$ & Core Line & $\begin{array}{l}\text { Obtuse } \\
\text { Plump }\end{array}$ \\
\hline Cavity & Medium & Clasping & Small \\
\hline $\begin{array}{l}\text { Acuminate } \\
\text { Acute }\end{array}$ & Shallow & Meeting & Tufted \\
\hline $\begin{array}{l}\text { Acute } \\
\text { Lipped }\end{array}$ & Narrow & Calyx Tube & Wide \\
\hline $\begin{array}{l}\text { Lipped } \\
\text { Obtuse }\end{array}$ & Wide & Conical & Flavor \\
\hline $\begin{array}{l}\text { Obtuse } \\
\text { Russeted }\end{array}$ & Skin & Funnel-shaped & Aromatic \\
\hline Symmetrical & $\begin{array}{l}\text { Dull } \\
\text { Glossy }\end{array}$ & $\begin{array}{l}\text { Urn-shaped } \\
\text { Long }\end{array}$ & $\begin{array}{l}\text { Flat } \\
\text { Sour }\end{array}$ \\
\hline $\begin{array}{l}\text { Narrow } \\
\text { Wide }\end{array}$ & $\begin{array}{l}\text { Glossy } \\
\text { Rough }\end{array}$ & Short & Sprightly \\
\hline $\begin{array}{l}\text { Wide } \\
\text { Deep }\end{array}$ & $\begin{array}{l}\text { Rough } \\
\text { Russet }\end{array}$ & Narrow & Sub-acid \\
\hline $\begin{array}{l}\text { Deep } \\
\text { Medium }\end{array}$ & Smooth & Wide & QUALITY \\
\hline $\begin{array}{l}\text { Medium } \\
\text { Shallow }\end{array}$ & Tender & Flesh & Best \\
\hline COLOR & Thin & Color ................. & Good \\
\hline $\begin{array}{l}\text { Color } \\
\text { Ground..................... }\end{array}$ & Tough & Texture & $\begin{array}{l}\text { Very good } \\
\text { Medium }\end{array}$ \\
\hline Ground ................. & Waxen & Coarse & $\begin{array}{l}\text { Medrum } \\
\text { Poor }\end{array}$ \\
\hline Blushed & Dots & Crisp & Very poor \\
\hline Mottled & Areolar & Dry & MARKET \\
\hline Striped & $\begin{array}{l}\text { Elongated } \\
\text { Stellate }\end{array}$ & $\begin{array}{l}\text { Fine } \\
\text { Firm }\end{array}$ & Distant \\
\hline Polish................... & $\begin{array}{l}\text { Stellate } \\
\text { Few }\end{array}$ & $\begin{array}{l}\text { Firm } \\
\text { Juicy }\end{array}$ & Local \\
\hline Prevailing effect... & Many & Medium & UsE \\
\hline CALYX & Large & Sweet & Cooking \\
\hline Closed & Medium & Tender & Dessert \\
\hline Open & Small & Tough & Market \\
\hline
\end{tabular}




\section{A STUDY OF THE APPLE}

Seasor

LOCALITY

Prodectivenfess

General Appearance

DESIRABILITY

HISTORY

REMARKS

Draw a longitudinal section of the fruit. 


\section{EXERCISE LI}

\section{A STUDY OF THE APPLE}

(Underscore or star the terms that apply to the variety of fruit being studied)

VARIETY

DA TF

Grou P

SyNONYMS

\begin{tabular}{|c|c|c|c|}
\hline Srze & Large & Compressed & Stamens \\
\hline Large & Medium & Raised & Basal \\
\hline Medium & Small & Rough & Marginal \\
\hline Small & Calyx Lobes & Submerged & Medial \\
\hline Form & $\begin{array}{l}\text { CALYX LOBES } \\
\text { Acuminate }\end{array}$ & Gray & Carpels \\
\hline Conical & $\begin{array}{l}\text { Acummate } \\
\text { Acute }\end{array}$ & Red & Cordate \\
\hline Irregular & Obtuse & Russet & Emarginate \\
\hline Oblate & Long & White & Ovate \\
\hline Oblong & Medium & Core & Round \\
\hline Oblique & Short & Abaxile & Tufted \\
\hline Ovate & Narrow & Axile. & SeEd \\
\hline Ribbed & Wide & Large & Acuminate \\
\hline $\begin{array}{l}\text { Roundish } \\
\text { Symmetrical }\end{array}$ & Separated at base & Medium & Acute \\
\hline symmetrical & BASIN & $\begin{array}{l}\text { Small } \\
\text { Closed }\end{array}$ & Flat \\
\hline STEM & -Abrupt & $\begin{array}{l}\text { Closed } \\
\text { Open }\end{array}$ & Large \\
\hline Long & Corrugated & $\begin{array}{l}\text { Open } \\
\text { Distant }\end{array}$ & Long \\
\hline Medium & Furrowed & Median & Medium \\
\hline Short & Obtuse & Sessile & Narrow \\
\hline Slender & Symmetrical & & Obtuse \\
\hline Thick & Deep & CORE LINE & Plump \\
\hline Cavity & Medium & Clasping & Small \\
\hline Acuminate & Shallow & & 'Tufted \\
\hline Acute & Narrow & Calyx Tube & Wide \\
\hline Lipped & Wide & Conical & Flavor \\
\hline Obtuse & SKIN & Funnel-shaped & Aromatic \\
\hline Russeted & Dull & Urn-shaped & Flat \\
\hline Symmetrical & Glossy & Long & Sour \\
\hline Narrow & Rough & Short & Sprightly \\
\hline Wide & Russet & Narrow & Sub-acid \\
\hline Deep & Smooth & Wide & QUALITY \\
\hline Medium & Tender & Flesil & Best \\
\hline Shallow & Thin & Color.... & Good \\
\hline Color & Tough & Texture & Very good \\
\hline Ground ............... & Waxen & Coarse & Medium \\
\hline Overlying & Dотs & Crisp & Poor \\
\hline Blushed & Areolar & Dry & Very poor \\
\hline $\begin{array}{l}\text { Mottled } \\
\text { Striped }\end{array}$ & Elongated & Fine & MARKET \\
\hline $\begin{array}{l}\text { Striped } \\
\text { Polish }\end{array}$ & Stellate & Firm & Distant \\
\hline $\begin{array}{l}\text { Polish................... } \\
\text { Prevailing effect. }\end{array}$ & Few & Juicy & Local \\
\hline Prevailing effect.. & Many & Medium & UsE \\
\hline CalyX & Large & Sweet & Cooking \\
\hline Closed & Medium & Tender & Dessert \\
\hline Open & Small & Tough & Market \\
\hline
\end{tabular}


A STUdy ÔF THE APPLE

SEAson

LOCALITY

Prodectiveness

General Appearance

Desirability

HistokY

REMARKS

Draw a longitudinal section of the fruit. 


\section{EXERCISE LII}

\section{A STUDY OF THE APPLE}

(Underscore or star the terms that apply to the variety of fruit being studied)

VARIETY

DATF

Grove

SyNonyms

\begin{tabular}{|c|c|c|c|}
\hline Size & Large & Compressed & Stamens \\
\hline Large & Medium & Raised & Basal \\
\hline Medium & Small & Rough & Marginal \\
\hline Small & CaLYX Lobes & Submerged & Medial \\
\hline Form & Acuminate & Gray & Carpels \\
\hline Conical & Acute & $\begin{array}{l}\text { Red } \\
\text { Russet }\end{array}$ & Cordate \\
\hline Irregular & Obtuse । & White & Emarginate \\
\hline Oblate & Long & Core & Ovate \\
\hline Oblong & Medium & $\begin{array}{l}\text { Abaxile } \\
\text { Abax }\end{array}$ & Round \\
\hline $\begin{array}{l}\text { Oblique } \\
\text { Ovate }\end{array}$ & $\begin{array}{l}\text { Short } \\
\text { Narrow }\end{array}$ & Axile & Tufted \\
\hline $\begin{array}{l}\text { Ovate } \\
\text { Ribbed }\end{array}$ & $\begin{array}{l}\text { Narrow } \\
\text { Wide }\end{array}$ & Large & SEED \\
\hline $\begin{array}{l}\text { Ribbed } \\
\text { Roundish }\end{array}$ & Wide & Medium & Acuminate \\
\hline $\begin{array}{l}\text { Roundish } \\
\text { Symmetrical }\end{array}$ & Separated at base & Small & Acute \\
\hline & BASIN & Closed & Flat \\
\hline $\begin{array}{l}\text { STEM } \\
\text { Long }\end{array}$ & Abrupt & Open & Large \\
\hline $\begin{array}{l}\text { Long } \\
\text { Medium }\end{array}$ & Corrugated & Distant & Long \\
\hline $\begin{array}{l}\text { Medium } \\
\text { Short }\end{array}$ & Furrowed & Median & $\begin{array}{l}\text { Medium } \\
\text { Narrow }\end{array}$ \\
\hline Slender & Obtuse & Sessile & $\begin{array}{l}\text { Narrow } \\
\text { Obtuse }\end{array}$ \\
\hline Thick & $\begin{array}{l}\text { Symmetrical } \\
\text { Deep }\end{array}$ & Core Line & Plump \\
\hline Cavity & Medium & Clasping & Small \\
\hline $\begin{array}{l}\text { Acuminate } \\
\text { Acute }\end{array}$ & Shallow & Meeting & Tufted \\
\hline $\begin{array}{l}\text { Acute } \\
\text { Lipped }\end{array}$ & Narrow & Calyx Tube & Wide \\
\hline $\begin{array}{l}\text { Lipped } \\
\text { Obtuse }\end{array}$ & Wide & Conical & Flavor \\
\hline $\begin{array}{l}\text { Obtuse } \\
\text { Russeted }\end{array}$ & Skin & Funnel-shaped & Aromatic \\
\hline Symmetrical & Dull & Urn-shaped & $\begin{array}{l}\text { Flat } \\
\text { Sour }\end{array}$ \\
\hline Narrow & $\begin{array}{l}\text { Glossy } \\
\text { Rough }\end{array}$ & $\begin{array}{l}\text { Long } \\
\text { Short }\end{array}$ & Sprightly \\
\hline Wide & $\begin{array}{l}\text { Rough } \\
\text { Russet }\end{array}$ & - Narrow & Sub-acid \\
\hline $\begin{array}{l}\text { Deep } \\
\text { Medium }\end{array}$ & Smooth & Wide & Quatity \\
\hline $\begin{array}{l}\text { Medium } \\
\text { Shallow }\end{array}$ & Tender & Flesh & Best \\
\hline Color & Thin & Color ................ & Good \\
\hline Ground $\ldots \ldots \ldots \ldots \ldots$ & $\begin{array}{l}\text { Tough } \\
\text { Waxen }\end{array}$ & Texture & $\begin{array}{l}\text { Very good } \\
\text { Medium }\end{array}$ \\
\hline $\begin{array}{l}\text { Overlying } \\
\text { Blushed }\end{array}$ & Dots & Coarse & Poor \\
\hline $\begin{array}{l}\text { Blushed } \\
\text { Mottled }\end{array}$ & Areolar & $\begin{array}{l}\text { Crisp } \\
\text { Dry }\end{array}$ & Very poor \\
\hline $\begin{array}{l}\text { Mottled } \\
\text { Striped }\end{array}$ & Elongated & $\begin{array}{l}\text { Dry } \\
\text { Fine }\end{array}$ & MaRKET \\
\hline $\begin{array}{c}\text { Striped } \\
\text { Polish.................. }\end{array}$ & Stellate & $\begin{array}{l}\text { Fine } \\
\text { Firm }\end{array}$ & Distant \\
\hline $\begin{array}{l}\text { Polish........... } \\
\text { Prevailing effect. }\end{array}$ & Few & Juicy & Local 。 \\
\hline & Many & Medium & UsE \\
\hline CALYX & Large & Sweet & Cooking \\
\hline Closed & Medium & Tender & Dessert \\
\hline Open & Small & Tough & Market \\
\hline
\end{tabular}


A STUDY OF THE APPLE

SEASON

LOCALITY

Pronuctiveness

General Appearance.

DESIRABILITY

HISTORY

REMARKS

Draw a longitudinal section of the fruit. 


\section{EXERCISE LIII}

\section{A STUDY OF THE APPLE}

(Underscore or star the terms that apply to the variety of fruit being studied)

VARIETY

DAte

Group

SyNonyus

\begin{tabular}{|c|c|c|c|}
\hline Size & Large & Compressed & Stamens \\
\hline Large & Medium & Raised & Basal \\
\hline Medium & Small & Rough & Marginal \\
\hline Small & CALYX LOBES & "Submerged & Medial \\
\hline ForM & $\begin{array}{l}\text { Acuminate } \\
\text { Acum }\end{array}$ & Gray & Carpels \\
\hline Conical & Acute & Red & Cordate \\
\hline Irregular & Obtuse & Russet & Emarginate \\
\hline Oblate & Long & White & Ovate \\
\hline Oblong & Medium & Core & Round \\
\hline Oblique & Short & Abaxile & Tufted \\
\hline Ovate & Narrow & Axile & SeEd \\
\hline Ribbed & Wide & Large & Acuminate \\
\hline Roundish & Separated at base & Medium & Acute \\
\hline Symmetrical & BAsin & $\begin{array}{l}\text { Small } \\
\text { Closed }\end{array}$ & Flat \\
\hline STEM & Abrupt & Open & Large \\
\hline Long & Corrugated & Distant & Long \\
\hline Medium & Furrowed & Median & Medium \\
\hline $\begin{array}{l}\text { Short } \\
\text { Slender }\end{array}$ & Obtuse & Sessile & $\begin{array}{l}\text { Narrow } \\
\text { Obtuse }\end{array}$ \\
\hline Thick & $\begin{array}{l}\text { Symmetrical } \\
\text { Deep }\end{array}$ & Core Line & Plump \\
\hline Cavity & Medium & Clasping & Small \\
\hline Acuminate & Shallow & Meeting & Tufted \\
\hline Acute & Narrow & Calyx Tube & Wide \\
\hline $\begin{array}{l}\text { Lipped } \\
\text { Obtuse }\end{array}$ & Wide & Conical & FLAYOR \\
\hline $\begin{array}{l}\text { Obtuse } \\
\text { Russeted }\end{array}$ & SkIN & Funnel-shaped & Aromatic \\
\hline $\begin{array}{l}\text { Russeted } \\
\text { Symmetrical }\end{array}$ & Dull & Urn-shaped & Flat \\
\hline $\begin{array}{l}\text { Symmetrical } \\
\text { Narrow }\end{array}$ & Glossy & $\begin{array}{l}\text { Long } \\
\text { Short }\end{array}$ & Sprightly \\
\hline Wide & $\begin{array}{l}\text { Rough } \\
\text { Russet }\end{array}$ & Narrow & Sub-acid \\
\hline Deep & Smooth & Wide & QUahity \\
\hline Medium & Tender & Flesh & Best \\
\hline Shallow & Thin & Color..... & Good \\
\hline Color & Tough & Texture & Very good \\
\hline Ground............... & Waxen & $\begin{array}{l}\text { 1EXTURE } \\
\text { Coarse }\end{array}$ & Medium \\
\hline Overlying & Dots & $\begin{array}{l}\text { Coarse } \\
\text { Crisp }\end{array}$ & Poor \\
\hline Blushed & Areolar & $\begin{array}{l}\text { Drisp } \\
\text { Dry }\end{array}$ & Very poor \\
\hline Mottled & Elongated & Fine & MARKET \\
\hline $\begin{array}{l}\text { Striped } \\
\text { Polish }\end{array}$ & Stellate & Firm & Distant \\
\hline $\begin{array}{l}\text { Polish.................. } \\
\text { Prevailing effect... }\end{array}$ & Few & Juicy & Local \\
\hline Prevalming entect.. & Many & Medium & UsE \\
\hline CALYX. & Large & Sweet & Cooking \\
\hline Closed & Medium & Tender & Dessert \\
\hline Open & Small & Tough & Market \\
\hline
\end{tabular}




\section{A STUDY OF THE APPLE}

SEASON

LOCALITY

Productiveness

Grieral Appearance.

DESIRABILITY

History

RrMARKS

Draw a longitudinal section of the fruit. 


\section{EXERCISE LIV}

\section{A STUDY OF THE APPLE}

(Underscore or star the terms that apply to the variety of fruit being studied)

VARIETY

DA TE

Group

SynoNyMs

\begin{tabular}{|c|c|c|c|}
\hline SIzE & Large & Compressed & Stamens \\
\hline Large & Medium & Raised & Basal \\
\hline Medium & Small & Rough & Marginal \\
\hline Small & CALyX Lobes & Submerged & Medial \\
\hline FORM & $\begin{array}{l}\text { CALYX LOBES } \\
\text { Acuminate }\end{array}$ & Gray & Carpels \\
\hline Conical & Acute & Red & Cordate \\
\hline Irregular & Obtuse & Russet & Emarginate \\
\hline Oblate & Long & White & Ovate \\
\hline Oblong & Medium & Core & Round \\
\hline Oblique. & Short & Abaxile & Tufted \\
\hline Ovate & Narrow & Axile & SeEd \\
\hline Ribbed & Wide & Large & Acuminate \\
\hline Roundish & Separated at base & Medium & Acute \\
\hline Symmetrical & BASIN & Small & Flat \\
\hline STEM & Abrupt & Closed & Large \\
\hline Long & & Open & Long \\
\hline Medium & $\begin{array}{l}\text { Corrugated } \\
\text { Furrowed }\end{array}$ & Distant & Medium \\
\hline Short & Obtuse & $\begin{array}{l}\text { Median } \\
\text { Sessile }\end{array}$ & Narrow \\
\hline Slender & Symmetrical & Sessile & Obtuse \\
\hline Thick & Deep & Core Line & Plump \\
\hline Cavity & Medium & Clasping & Small \\
\hline Acuminate & Shallow & Meeting & Tufted \\
\hline Acute & Narrow & Calyx Tube & Wide \\
\hline Lipped & Wide & Conical & Flavor \\
\hline Obtuse & SkIN & Funnel-shaped & Aromatic \\
\hline Russeted & Dull & Urn-shaped & Flat \\
\hline Symmetrical & Glossy & Long & Sour \\
\hline Narrow & Rough & Short & Sprightly \\
\hline Wide & Russet & Narrow & Sub-acid \\
\hline Deep & Smooth & Wide & QUALITy \\
\hline Medium & Tender & Flesh & Best \\
\hline Shallow & Thin & Color..... & Good \\
\hline Color & Tough & Texture & Very good \\
\hline Ground................. & Waxen & $\begin{array}{l}\text { Texture } \\
\text { Coarse }\end{array}$ & Medium \\
\hline Overlying & Dots & $\begin{array}{l}\text { Coarse } \\
\text { Crisp }\end{array}$ & Poor \\
\hline Blushed & Areolar & $\begin{array}{l}\text { Crisp } \\
\text { Dry }\end{array}$ & Very poor \\
\hline Mottled & Elongated & $\begin{array}{l}\text { Dry } \\
\text { Fine }\end{array}$ & Market \\
\hline Striped & Stellate & Firm & Distant \\
\hline Polish................... & Few & Juicy & Local \\
\hline Prevailing effect.. & Many & Medium & UsE \\
\hline CALYX & Large & Sweet & Cooking \\
\hline Closed & Medium & Tender & Dessert \\
\hline Open & Small & Tough & Market \\
\hline
\end{tabular}




\section{A STUDY OF THE APPLE}

SEASON

LOCALITY

Productivenfiss

Geveral Appearance

Desirability

HistoRY

Remarks

Draw a longitudinal section of the fruit. 


\section{EXERCISE LV}

\section{A STUDY OF THE GRAPE}

(Underscore or star the terms that apply to the variety of fruit being studied)

VARIETY

DATE.

Group

Synonyms

\begin{tabular}{|c|c|c|c|}
\hline BERRY & Wide & JUICINESS & Pigment............ \\
\hline Size & Winged & Medium & FLAVor \\
\hline Large & Irregular & Dry & Astringent \\
\hline Medium & Regular & Juicy & Foxy \\
\hline Small & Long & Clear & Neutral \\
\hline Uniform & Medium & Pink & SEED \\
\hline Variable & $\begin{array}{l}\text { Short } \\
\text { Double-shouldered }\end{array}$ & Purple & Number.... \\
\hline ForM & Single-shouldered & Thin & Size \\
\hline Oblate & NUMBER PER & Texture & Large \\
\hline $\begin{array}{l}\text { Oval } \\
\text { Roundish }\end{array}$ & NOMBEК PEK & Coarse & $\begin{array}{l}\text { Small } \\
\text { Smam }\end{array}$ \\
\hline Color & OMPACTNESS & $\begin{array}{l}\text { Melting } \\
\text { Slippery }\end{array}$ & Shape \\
\hline Amber & Loose & Solid & Notched \\
\hline Black & Medium & Stringy & $\begin{array}{l}\mathrm{O} \\
\mathrm{Pl}\end{array}$ \\
\hline Blue & Peduncle & Tender & $\begin{array}{l}\text { Plump } \\
\text { Blunt }\end{array}$ \\
\hline $\begin{array}{l}\text { Green } \\
\text { Purple }\end{array}$ & Long & Tough & Pointed \\
\hline $\begin{array}{l}\text { Purple } \\
\text { Red }\end{array}$ & Medium & Aroma & Rounded \\
\hline Violet & Short & matic & \\
\hline White & Slender & $\begin{array}{l}\text { Foxy } \\
\text { Spicy }\end{array}$ & \\
\hline Yellow & Thick & Flavor & $\begin{array}{l}\text { Long } \\
\text { Medium }\end{array}$ \\
\hline $\begin{array}{l}\text { Glossy } \\
\text { Translucent }\end{array}$ & Pedicel & Acid & Short \\
\hline Transiucen & Long & Foxy & Colo \\
\hline Вцоом & Medium & Mild & wn \\
\hline Abundance....... & Short & Spicy & llow \\
\hline Color................. & Slender & Sweet & RAPI \\
\hline APEX & Thick & Tart & rdlike \\
\hline $\begin{array}{l}\text { Adherence of } \\
\text { stigma }\end{array}$ & $\begin{array}{l}\text { Swellings } \\
\text { Warts }\end{array}$ & $\begin{array}{l}\text { Vinous } \\
\text { Quality }\end{array}$ & \\
\hline ADHESION & BRUSH & Best & $\begin{array}{l}\text { Obscure } \\
\text { Prominent }\end{array}$ \\
\hline $\begin{array}{l}\text { Drops } \\
\text { Persistent }\end{array}$ & 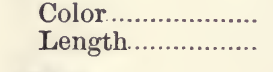 & $\begin{array}{l}\text { Very good } \\
\text { Medium }\end{array}$ & $\begin{array}{l}\text { Chalaza } \\
\text { Above cent }\end{array}$ \\
\hline CLUSTER & FLESH & Poor & Below center \\
\hline Size & Color & Very poor & Circular \\
\hline Large & Greenish & $\begin{array}{l}\text { SEPARATION FROM } \\
\text { SEED }\end{array}$ & $\begin{array}{l}\text { Distinct } \\
\text { Obscure }\end{array}$ \\
\hline $\begin{array}{l}\text { Medium } \\
\text { Small }\end{array}$ & Red & With difficulty & Oval \\
\hline Fory & Translucent & Easily & UsE \\
\hline $\begin{array}{l}\text { Form } \\
\text { Cylindrical }\end{array}$ & Transparent & $\begin{array}{l}\text { Skin } \\
\text { Medium }\end{array}$ & $\begin{array}{l}\text { Dessert } \\
\text { Kitchen }\end{array}$ \\
\hline Ovate & Firmness & Thick & Market \\
\hline dish & Firm & Th & $\sin$ \\
\hline & Medium & Tender & ping \\
\hline Tap & Soft & Tough & Wine \\
\hline
\end{tabular}


A STUDY OF THE GRAPE

SEASON

LOCALITY

Proplctiveness

Geveral Appearance

DESIRABILITY

History

RFMARKS

Make drawings of several different seeds, showing the position and the shape of the chalaza. 


\section{EXERCISE LVI}

\section{A STUDY OF THE GRAPE}

(Underscore or star the terms that apply to the variety of fruit being studied)

VARIETY

DATE

Group

SyNONYMS

\begin{tabular}{|c|c|c|c|}
\hline BERRY & Wide & JuICINESS & Pigment........... \\
\hline Size & Winged & Medium & Flavor \\
\hline Large & Irregular & Dry & Astringent \\
\hline Medium & Regular & Juicy & Foxy \\
\hline Small & Long & Clear & Neutral \\
\hline Uniform & Medium & Pink & SEED \\
\hline Variable & $\begin{array}{l}\text { Short } \\
\text { Double-shouldered }\end{array}$ & Purple & Number...... \\
\hline Form & Single-shouldered & Thin & Size \\
\hline Oblate & NUMBER PER SHOOT & Texture & Large \\
\hline $\begin{array}{l}\text { Oval } \\
\text { Roundish }\end{array}$ & NUMBEK PEK DHOOT & Coarse & $\begin{array}{l}\text { Medium } \\
\text { Small }\end{array}$ \\
\hline Roundisn & COMPACTNESS & Melting & ShaPe \\
\hline $\begin{array}{l}\text { Color } \\
\text { Amber }\end{array}$ & $\begin{array}{l}\text { Compact } \\
\text { Loose }\end{array}$ & $\begin{array}{l}\text { Slippery } \\
\text { Solid }\end{array}$ & Notched \\
\hline Black & Medium & Stringy & Oblong \\
\hline Blue & & Tender & Plump \\
\hline Green & PEDUNCLE & Tough & $\begin{array}{l}\text { Blunt } \\
\text { Pointed }\end{array}$ \\
\hline $\begin{array}{l}\text { Purple } \\
\text { Red }\end{array}$ & Long & Aroma & Rounded \\
\hline $\begin{array}{l}\text { Red } \\
\text { Violet }\end{array}$ & $\begin{array}{l}\text { Medium } \\
\text { Short }\end{array}$ & Aromatic & Narrow \\
\hline $\begin{array}{l}\text { Violet } \\
\text { White }\end{array}$ & $\begin{array}{l}\text { Short } \\
\text { Slender }\end{array}$ & Foxy & Wide \\
\hline $\begin{array}{l}\text { White } \\
\text { Yellow }\end{array}$ & Thick & Spicy & Long \\
\hline $\begin{array}{l}\text { Yellow } \\
\text { Glossy }\end{array}$ & Pedicel & Flavor & Medium \\
\hline Translucent & Long & $\begin{array}{l}\text { Acid } \\
\text { Foxy }\end{array}$ & $\begin{array}{l}\text { Short } \\
\text { Color }\end{array}$ \\
\hline BLоом & Medium & Mild & Brown \\
\hline Abundance....... & Short & Spicy & Yellow \\
\hline Color................ & Slender & Sweet & RAPHE \\
\hline APEX & Thick & Tart & Cordlike \\
\hline Adherence of & Swellings & Vinous & Large \\
\hline stigma & Warts & QUALITY & Small \\
\hline ADHESION & BRUSH & $\begin{array}{l}\text { Best } \\
\text { Good }\end{array}$ & $\begin{array}{l}\text { Obscure } \\
\text { Prominent }\end{array}$ \\
\hline Drops & Color................... & Very good & $\begin{array}{l}\text { Prominent } \\
\text { CHALAZA }\end{array}$ \\
\hline Persistent & Length................. & Medium & Above center \\
\hline CLUSTER & FLESH & Poor & Below center \\
\hline SIzE & Color & Very poor & Circular \\
\hline Large & Greenish & $\begin{array}{l}\text { SEPARATION FROM } \\
\text { SEED }\end{array}$ & $\begin{array}{l}\text { Distinct } \\
\text { Obscure }\end{array}$ \\
\hline Medium & Red & With difficulty & $\begin{array}{l}\text { Oval } \\
\text { Ovalure }\end{array}$ \\
\hline Small & White & Easily & USE \\
\hline Form & $\begin{array}{l}\text { Translucent } \\
\text { Transparent }\end{array}$ & Skin & Dessert \\
\hline Cylindrical & Firmness & Medium & Kitchen \\
\hline Ovate & & Thick & Market \\
\hline Roundish & Firm & Thin & Raisin \\
\hline Slender & Medium & Tender & Shipping \\
\hline Tapering & Soft & Tough & Wine \\
\hline
\end{tabular}




\section{A STUDY OF THE GRAPE}

SEASON

LOCALITY

Productiveness

General Appearance.

DESIRABILITY

HISTORY

REMARKS

Make drawings of several different seeds, showing the position and the shape of the chalaza. 


\section{EXERCISE LVII}

\section{A STUDY OF THE GRAPE}

(Underscore or star the terms that apply to the variety of fruit being studied)

VARIETY

DA TF

Group

SYNONYMS

\begin{tabular}{|c|c|c|c|}
\hline BERRY & Wide & JUICINESS & Pigment........... \\
\hline SIZE & Winged & Medium & Flavor \\
\hline Large & Irregular & Dry & Astringent \\
\hline Medium & Regular & Juicy & Foxy \\
\hline Small & Long & Clear & Neutral \\
\hline Uniform & Medium & Pink & SEED \\
\hline Variable & $\begin{array}{l}\text { Short } \\
\text { Double-shouldered }\end{array}$ & $\begin{array}{l}\text { Purple } \\
\text { Thick }\end{array}$ & Number...... \\
\hline ForM & Single-shouldered & Thin & Size \\
\hline Oblate & NuMBER PER SHOOT & Texture & Large \\
\hline $\begin{array}{l}\text { Oval } \\
\text { Roundish }\end{array}$ & L & Coarse & $\begin{array}{l}\text { Medium } \\
\text { Small }\end{array}$ \\
\hline Color & Compact & $\begin{array}{l}\text { Melting } \\
\text { Slippery }\end{array}$ & SHape \\
\hline Amber & Loose & Solid & Notched \\
\hline Black & Medium & Stringy & Oblong \\
\hline Blue & Peduncle & Tender & $\begin{array}{l}\text { Plump } \\
\text { Blunt }\end{array}$ \\
\hline Green & Long & 'Tough & Pointed \\
\hline $\begin{array}{l}\text { Purple } \\
\text { Red }\end{array}$ & Medium & Aroma & Rounded \\
\hline $\begin{array}{l}\text { Red } \\
\text { Violet }\end{array}$ & Short & Aromatic & Narrow \\
\hline White & Slender & Foxy & Wide \\
\hline Yellow & Thick & $\begin{array}{r}\text { Spicy } \\
\text { FLAVor }\end{array}$ & Long \\
\hline Glossy & Pedicel & $\begin{array}{l}\text { FLAVOR } \\
\text { Acid }\end{array}$ & $\begin{array}{l}\text { Medium } \\
\text { Short }\end{array}$ \\
\hline Translucent & Long & Foxy & Color \\
\hline BLOOM & Medium & Mild & Brown \\
\hline Abundance....... & Short & Spicy & Yellow \\
\hline Color................ & Slender & Sweet & Raphe \\
\hline APEX & Thick & Tart & Cordlike \\
\hline $\begin{array}{l}\text { Adherence of } \\
\text { stigma }\end{array}$ & $\begin{array}{l}\text { Swellings } \\
\text { Warts }\end{array}$ & $\begin{array}{l}\text { Vinous } \\
\text { Quality }\end{array}$ & $\begin{array}{l}\text { Large } \\
\text { Small }\end{array}$ \\
\hline ADHesion & BRUSH & Best & $\begin{array}{l}\text { Obscure } \\
\text { Prominent }\end{array}$ \\
\hline $\begin{array}{l}\text { Drops } \\
\text { Persistent }\end{array}$ & $\begin{array}{l}\text { Color...................... } \\
\text { Length............... }\end{array}$ & $\begin{array}{l}\text { Very good } \\
\text { Medium }\end{array}$ & Chaldaza \\
\hline CLUSTER & FLESH & Poor & Below center \\
\hline Size & Color & Very poor & Circular \\
\hline Large & Greenish & $\begin{array}{l}\text { SEPARATION FROM } \\
\text { SEED }\end{array}$ & $\begin{array}{l}\text { Distinct } \\
\text { Obscure }\end{array}$ \\
\hline $\begin{array}{l}\text { Medium } \\
\text { Small }\end{array}$ & Red & With difficulty & Oval \\
\hline FORM & Translucent & Easily & UsE \\
\hline $\begin{array}{l}\text { Form } \\
\text { Cylindrical }\end{array}$ & Transparent & Skin & Dessert \\
\hline Ovate & Firmess & $\begin{array}{l}\text { Medium } \\
\text { Thick }\end{array}$ & $\begin{array}{l}\text { Kitchen } \\
\text { Market }\end{array}$ \\
\hline Roundish & Firm & Thin & Raisin \\
\hline Slender & Medium & Tender & Shipping \\
\hline Tapering & Soft & Tough & Wine \\
\hline
\end{tabular}


A STUDY OF THE GRAPE

SEASON

LOCALITY

Prodectiveness.

General Appearance.

Desirability

Histor $)^{\circ}$

REMARKS

Make drawings of several different seeds, showing the position and the shape of the chalaza. 


\section{EXERCISE LVIII}

\section{A STUDY OF THE GRAPE}

(Underscore or star the terms that apply to the variety of fruit being studied)

VARIETY

DATE

Grovp

SYNONYMS

\begin{tabular}{|c|c|c|c|}
\hline BERRY & Wide & JuICINESS & Pigment.......... \\
\hline Size & Winged & Medium & FLAYOR \\
\hline Large & Irregular & Dry & Astringent \\
\hline Medium & Regular & Juicy & Foxy \\
\hline Small & Long & Clear & Neutral \\
\hline Uniform & $\begin{array}{l}\text { Medium } \\
\text { Short }\end{array}$ & $\begin{array}{l}\text { Pink } \\
\text { Purnle }\end{array}$ & SEED \\
\hline Variable & $\begin{array}{l}\text { Short } \\
\text { Double-shouldered }\end{array}$ & $\begin{array}{l}\text { Purple } \\
\text { Thick }\end{array}$ & Number...... \\
\hline Form & Single-shouldered & Thin & Size \\
\hline Oblate & NuMber per Shoot & Texture & Large \\
\hline $\begin{array}{l}\text { Oval } \\
\text { Roundish }\end{array}$ & & Coarse & $\begin{array}{l}\text { Medium } \\
\text { Small }\end{array}$ \\
\hline Roundish & COMPACTNESS & Melting & $\begin{array}{l}\text { Small } \\
\text { SHAPE }\end{array}$ \\
\hline $\begin{array}{l}\text { Color } \\
\text { Amber }\end{array}$ & & Slippery & $\begin{array}{l}\text { SHAPE } \\
\text { Notched }\end{array}$ \\
\hline $\begin{array}{l}\text { Amber } \\
\text { Black }\end{array}$ & $\begin{array}{l}\text { Loose } \\
\text { Medium }\end{array}$ & $\begin{array}{l}\text { Solid } \\
\text { Stringy }\end{array}$ & $\begin{array}{l}\text { Notched } \\
\text { Oblong }\end{array}$ \\
\hline $\begin{array}{l}\text { Black } \\
\text { Blue }\end{array}$ & & $\begin{array}{l}\text { Stringy } \\
\text { Tender }\end{array}$ & Plump \\
\hline Green & Peduncle & Tough & Blunt \\
\hline Purple & Long & Aroma & Pointed \\
\hline $\begin{array}{l}\text { Red } \\
\text { Violet }\end{array}$ & Medium & Aromatic & $\begin{array}{l}\text { Rounded } \\
\text { Narrow }\end{array}$ \\
\hline $\begin{array}{l}\text { Violet } \\
\text { White }\end{array}$ & $\begin{array}{l}\text { Short } \\
\text { Slender }\end{array}$ & Foxy & $\begin{array}{l}\text { Narrow } \\
\text { Wide }\end{array}$ \\
\hline $\begin{array}{l}\text { White } \\
\text { Yellow }\end{array}$ & Thick & Spicy & Long \\
\hline Glossy & Pedicel & Flavor & Medium \\
\hline Translucent & Long & Acid & Short \\
\hline Вцоом & Medium & $\begin{array}{l}\text { Foxy } \\
\text { Mild }\end{array}$ & $\begin{array}{l}\text { Color } \\
\text { Brown }\end{array}$ \\
\hline Abundance....... & Short & Spicy & Yellow \\
\hline Color..................... & Slender & Sweet & $R_{\text {APHE }}$ \\
\hline APEX & Thick & Tart & Cordlike \\
\hline $\begin{array}{l}\text { Adherence of } \\
\text { stigma }\end{array}$ & $\begin{array}{l}\text { Swellings } \\
\text { Warts }\end{array}$ & $\begin{array}{l}\text { Vinous } \\
\text { QuALITY }\end{array}$ & $\begin{array}{l}\text { Large } \\
\text { Small }\end{array}$ \\
\hline ADHESION & BRUSH & Best & Obscure \\
\hline Drops & 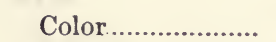 & Good & Prominent \\
\hline Persistent & 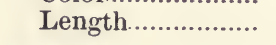 & $\begin{array}{l}\text { Very good } \\
\text { Medium }\end{array}$ & Chalaza \\
\hline CLUSTER & FLESH & Poor & $\begin{array}{l}\text { Above center } \\
\text { Below center }\end{array}$ \\
\hline SIZE & Color & Very poor & Circular \\
\hline Large & Greenish & Separation From & Distinct \\
\hline Medium & Red & SEED & Obscure \\
\hline Sinall & White & $\begin{array}{l}\text { With difficulty } \\
\text { Easily }\end{array}$ & $\begin{array}{l}\text { Oval } \\
\text { UsE }\end{array}$ \\
\hline FORM & Translucent & SkiN & Dessert \\
\hline Cylindrical & Transparent & Medium & Kitchen \\
\hline Ovate & FirmNeSS & Thick & Market \\
\hline Roundish & Firm & Thin & Raisin \\
\hline Slender & Medium & Tender & Shipping \\
\hline Tapering & Soft & Tough & Wine \\
\hline
\end{tabular}


A STUDY OF THE GRAPE

Srason

LOCALITY

Productiveness

General Appearance

DesirabiLity

IIISTORY

RFMARKs

Make drawings of several different seeds, showing the position and the shape of the chalaza. 


\section{EXERCISE LIX}

\section{A STUDY OF THE GRAPE}

(Underscore or star the terms that apply to the variety of fruit being studied)

VARIETY

DATE

Group

SYNONYMS

\begin{tabular}{|c|c|c|c|}
\hline BERRY & Wide & JuICINESS & Pigment........... \\
\hline Size & Winged & Medium & Flavor \\
\hline Large & Irregular & Dry & Astringent \\
\hline Medium & Regular & Juicy & Foxy \\
\hline Small & Long & Clear & Neutral \\
\hline Uniform & Medium & Pink & SEED \\
\hline Variable & $\begin{array}{l}\text { Short } \\
\text { Double-shouldered }\end{array}$ & Purple & 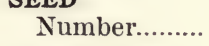 \\
\hline ForM & Single-shouldered & Thin & Size \\
\hline Oblate & Number per Shoot & Texture & Large \\
\hline $\begin{array}{l}\text { Oval } \\
\text { Roundish }\end{array}$ & CoMpaCtress & Coarse & $\begin{array}{l}\text { Medium } \\
\text { Small }\end{array}$ \\
\hline Color & Compact & $\begin{array}{l}\text { Melting } \\
\text { Slippery }\end{array}$ & Shape \\
\hline Amber & Loose & Solid & Notched \\
\hline Black & Medium & Stringy & Oblong \\
\hline Blue & Peduncle & Tender & $\begin{array}{l}\text { Plump } \\
\text { Blunt }\end{array}$ \\
\hline Green & Long & Tough & Pointed \\
\hline $\begin{array}{l}\text { Purple } \\
\text { Red }\end{array}$ & Medium & Aroma & Rounded \\
\hline $\begin{array}{l}\text { Red } \\
\text { Violet }\end{array}$ & Short & Aromatic & Narrow \\
\hline White & Slender & $\begin{array}{l}\text { Foxy } \\
\text { Spicy }\end{array}$ & Wide \\
\hline Yellow & Thick . & $\begin{array}{l}\text { Spley } \\
\text { FLAVor }\end{array}$ & $\begin{array}{l}\text { Long } \\
\text { Medium }\end{array}$ \\
\hline $\begin{array}{l}\text { Glossy } \\
\text { Translucent }\end{array}$ & Pedicel & Acid & Short \\
\hline ransiucent & Long & Foxy & Color \\
\hline Вцоом & Medium & Mild & Brown \\
\hline Abundance....... & Short & Spicy & Yellow \\
\hline Color................ & Slender & Sweet & RAPIIE \\
\hline APEX & $\begin{array}{l}\text { Thick } \\
\text { Swellings }\end{array}$ & Tart & Cordlike \\
\hline $\begin{array}{l}\text { Adherence of } \\
\text { stigma }\end{array}$ & $\begin{array}{l}\text { Swellings } \\
\text { Warts }\end{array}$ & Quality & $\begin{array}{l}\text { Large } \\
\text { Small }\end{array}$ \\
\hline ADHesion & Brush & Best & $\begin{array}{l}\text { Obscure } \\
\text { Prominent }\end{array}$ \\
\hline $\begin{array}{l}\text { Drops } \\
\text { Persistent }\end{array}$ & $\begin{array}{l}\text { Color ..................... } \\
\text { Length.............. }\end{array}$ & $\begin{array}{l}\text { Very good } \\
\text { Medium }\end{array}$ & Challaza \\
\hline CLUSTER & FLESH & Poor & Below center \\
\hline SIzE & Color & $\begin{array}{l}\text { Very poor } \\
\text { SEP }\end{array}$ & Circular \\
\hline Large & Greenish & $\begin{array}{l}\text { SEPARATION FROM } \\
\text { SEED }\end{array}$ & $\begin{array}{l}\text { Distinct } \\
\text { Obscure }\end{array}$ \\
\hline $\begin{array}{l}\text { Medium } \\
\text { Small }\end{array}$ & Red & With difficulty & Oval \\
\hline Form & Translucent & Easily & UsE \\
\hline Cylindrical & Transparent & $\begin{array}{l}\text { SkIN } \\
\text { Medium }\end{array}$ & $\begin{array}{l}\text { Dessert } \\
\text { Kitchen }\end{array}$ \\
\hline Ovate & Firmness & Thick & Market \\
\hline Roundish & Firm & Thin & Raisin \\
\hline Slender & Medium & Tender & Shipping \\
\hline Tapering & Soft & Tough & Wine \\
\hline
\end{tabular}




\section{A STUDY OF THE GRAPE}

SEASON

LOCALITY

Productiveness

General Appearance.

Desirability

HistoRY

Remarks

Make drawings of several different seeds, showing the position and the shape of the chalaza. 


\section{EXERCISE LX}

\section{A STUDY OF THE GRAPE}

(Underscore or star the terms that apply to the variety of fruit being studied)

VARIETY

DATE

Group

SYNONYMS

\begin{tabular}{|c|c|c|c|}
\hline BERRY & Wide & JUICINESS & Pigment... \\
\hline Size & Winged & Medium & Flavor \\
\hline Large & Irregular & Dry & Astringent \\
\hline Medium & Regular & Juicy & Foxy \\
\hline Small & Long & Clear & Neutral \\
\hline Uniform & Medium & Pink & SEED \\
\hline Variable & $\begin{array}{l}\text { Short } \\
\text { Double-shouldered }\end{array}$ & Purple & Number...... \\
\hline ForM & Single-shouldered & $\begin{array}{l}\text { Thlek } \\
\text { Thin }\end{array}$ & Size \\
\hline Oblate & & Texture & Large \\
\hline Oval & NUMBER PER SHOOT & Coarse & $\begin{array}{l}\text { Medium } \\
\text { Small }\end{array}$ \\
\hline Roundish & CoMpaCtNess & Melting & Shape \\
\hline $\begin{array}{l}\text { Color } \\
\text { Amber }\end{array}$ & $\begin{array}{l}\text { Compact } \\
\text { Loose }\end{array}$ & $\begin{array}{l}\text { Slippery } \\
\text { Solid }\end{array}$ & Notched \\
\hline Black & Medium & Stringy & Oblong \\
\hline Blue & Peduncle & Tender & $\begin{array}{l}\text { Plump } \\
\text { Blunt }\end{array}$ \\
\hline $\begin{array}{l}\text { Green } \\
\text { Purple }\end{array}$ & Long & Tough & Pointed \\
\hline $\begin{array}{l}\text { Purple } \\
\text { Red }\end{array}$ & Medium & Arona & Rounded \\
\hline Violet & Short & Aromatic & Narrow \\
\hline White & Slender & Foxy & Wide \\
\hline Yellow & Thick & $\begin{array}{r}\text { Spicy } \\
\text { Flavor }\end{array}$ & Long \\
\hline Glossy & Pedicel & $\begin{array}{l}\text { Flavor } \\
\text { Acid }\end{array}$ & $\begin{array}{l}\text { Medium } \\
\text { Short }\end{array}$ \\
\hline Translucent & Long & Foxy & $\begin{array}{l}\text { Short } \\
\text { Color }\end{array}$ \\
\hline BLoom & Medium & Mild & Brown \\
\hline Abundance....... & Short & Spicy & Yellow \\
\hline Color................ & Slender & Sweet & RAPHE \\
\hline APEX & Thick & Tart & Cordlike \\
\hline Adherence of & $\begin{array}{l}\text { Swellings } \\
\text { Warts }\end{array}$ & $\begin{array}{l}\text { Vinous } \\
\text { QuALITy }\end{array}$ & Large \\
\hline ADHESION & Brush & Best & Obscure \\
\hline $\begin{array}{l}\text { Drops } \\
\text { Dron }\end{array}$ & 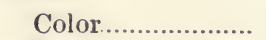 & $\begin{array}{l}\text { Good } \\
\text { Yery good }\end{array}$ & Prominent \\
\hline Persistent & Length............... & $\begin{array}{l}\text { Very good } \\
\text { Medium }\end{array}$ & $\begin{array}{l}\text { Chalaza } \\
\text { Above center }\end{array}$ \\
\hline CLUSTER & FLESH & Poor & Below center \\
\hline SizE & Color & Very poor & Circular \\
\hline Large & Greenish & $\begin{array}{l}\text { SeParation FROM } \\
\text { SEED }\end{array}$ & Distinct \\
\hline Medium & Red & $\begin{array}{l}\text { SEED } \\
\text { With difficulty }\end{array}$ & $\begin{array}{l}\text { Obscure } \\
\text { Oval }\end{array}$ \\
\hline Small & White & Easily & UsE \\
\hline $\begin{array}{l}\text { Form } \\
\text { Cvlindrical }\end{array}$ & $\begin{array}{l}\text { Translucent } \\
\text { Transparent }\end{array}$ & Skin & Dessert \\
\hline Ovate & Firmness & $\begin{array}{l}\text { Medium } \\
\text { Thick }\end{array}$ & $\begin{array}{l}\text { Kitclien } \\
\text { Market }\end{array}$ \\
\hline Roundish & Firm & Thin & Raisin \\
\hline Slender & Medium & Tender & Shipping \\
\hline Tapering & Soft & Tough & Wine \\
\hline
\end{tabular}




\section{A STUDY OF THE GRAPE}

SEAson

LOCALITY

Productiveness

General Appearance

DESIRABILITY

HISTORY

\section{REMARKS}

Make drawings of several different seeds, showing the position and the shape of the chalaza. 


\section{EXERCISE LXI}

\section{A STUDY OF THE PEACH}

(Underscore or star the terms that apply to the variety of fruit being studied)

VARIETY

DATE

Grou P

SYNONYMS

\begin{tabular}{|c|c|c|}
\hline Size & Prolonged tip & Quality \\
\hline Large & & Best \\
\hline Medium & Dots & Very good \\
\hline Small & 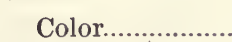 & $\begin{array}{l}\text { Good } \\
\text { Fair }\end{array}$ \\
\hline FORM & Conspicuous & Poor \\
\hline Compressed & $\begin{array}{l}\text { Inconspicuous } \\
\text { Few }\end{array}$ & Very poor \\
\hline Conical & Numerous & UsE \\
\hline $\begin{array}{l}\text { Oblate } \\
\text { Oblong }\end{array}$ & Size.................. & Dessert \\
\hline Oval & Flesh & Kitchen \\
\hline $\begin{array}{l}\text { Round } \\
\text { Halves equal }\end{array}$ & Green & Market \\
\hline $\begin{array}{l}\text { Halves equal } \\
\text { Halves unequal }\end{array}$ & Red & PIT \\
\hline & $\begin{array}{l}\text { White } \\
\text { Yellow }\end{array}$ & Adhesion \\
\hline Creamy & & Cling \\
\hline $\begin{array}{l}\text { Creamy } \\
\text { Green }\end{array}$ & JUICE & Free \\
\hline $\begin{array}{l}\text { Red } \\
\text { White }\end{array}$ & Dry & Half free \\
\hline $\begin{array}{l}\text { White } \\
\text { Yellow }\end{array}$ & Juicy & Size \\
\hline $\begin{array}{l}\text { Yellow } \\
\text { Mottled }\end{array}$ & $\begin{array}{l}\text { Color } \\
\text { Clear }\end{array}$ & Large \\
\hline Mottled & $\begin{array}{l}\text { Clear } \\
\text { Dark }\end{array}$ & Medium \\
\hline $\begin{array}{l}\text { Cavity } \\
\text { Deep }\end{array}$ & Light & \\
\hline $\begin{array}{l}\text { Deep } \\
\text { Medium }\end{array}$ & Pink & Shape \\
\hline $\begin{array}{l}\text { Medium } \\
\text { Shallow }\end{array}$ & Texture & Angular \\
\hline Narrow & Coarse & $\begin{array}{l}\text { Flattened } \\
\text { Necked }\end{array}$ \\
\hline Wide & Crisp & Oblique \\
\hline Suture & Firm & Obovate \\
\hline A mere line & $\begin{array}{l}\text { Fine } \\
\text { Melting }\end{array}$ & Oval \\
\hline Indistinet & Stringy & $\begin{array}{l}\text { Ovate } \\
\text { Plump }\end{array}$ \\
\hline Lacking & Tender & $\begin{array}{l}\text { Blunt } \\
\text { Blunt }\end{array}$ \\
\hline Prominent & Medium & Pointed \\
\hline Continuous & Tough & Prolonged \\
\hline Deep & Flayor & Roundish \\
\hline Shallow & FLAVOR & Winged \\
\hline APEX & $\begin{array}{l}\text { Flat } \\
\text { Mild }\end{array}$ & Surface \\
\hline Depressed & Sour & Pitted \\
\hline Flattened & Sweet & Rough \\
\hline Pointed & Sub-acid & Smooth \\
\hline & {$[186]$} & \\
\hline
\end{tabular}




\section{A STUDY OF THE PEACH}

Season

LOCALITY

Productiveness

General Appearance

Desirabilit Y

HISTORY

REMARKS

Draw a longitudinal section of the fruit and make a drawing of the seed. 


\section{EXERCISE LXII}

\section{A STUDY OF THE PEACH}

(Underscore or star the terms that apply to the variety of fruit being studied)

VARIETY

DATE

Group

SYNONYMS

\section{Size}

Large

Medium

Small

\section{ForM}

Compressed

Conical

Oblate

Oblong

Oval

Round

Halves equal

Halves unequal

\section{Color}

\section{Creamy}

Green

Red

White

Yellow

Mottled

\section{Cavity}

Deep

Medium

Shallow

Narrow

Wide

\section{Suture}

A mere line

Indistinct

Lacking

Prominent

Continuous

Deep

Shallow

\section{A pex}

Depressed

Flattened

Pointed
Prolonged tip

Roundish

Dots

Color.

Conspicuous

Inconspicuous

Few

Numerous

Size

Flesh

Green

Red

White

Yellow

Juice

Dry

Juicy

Color

Clear

Dark

Light

Pink

Texture

Coarse

Crisp

Firm

Fine

Melting

Stringy

Tender

Medium

Tough

Flavor

Flat

Mild

Sour

Sweet

Sub-acid

[188]
Quality

Best

Very good

Good

Fair

Poor

Very poor

UsE

Dessert

Kitchen

Market

PIT

Adhesion

Cling

Free

Half free

Size

Large

Medium

Small

Shape

Angular

Flattened

Necked

Oblique

Obovate

Oval

Ovate

Plump

Blunt

Pointed

Prolonged

Roundish

Winged

Surface

Pitted

Rough

Smooth 


\section{A STUDY OF THE PEACH}

Season

LOCALITY

Productiveness

Greneral Appearance.

DESIRABILITY

HisTORY

REMAKKS

Draw a longitudinal section of the fruit and make a drawing of the seed. 


\section{EXERCISE LXIII}

\section{A STUDY OF THE PEACH}

(Underscore or star the terms that apply to the variety of fruit being studied)

VARIETY

DATE

Group

SyNONYMS

\begin{tabular}{|c|c|c|}
\hline Size & Prolonged tip & Quality \\
\hline Large & Roundish & Best \\
\hline Medium & Dots & Very good \\
\hline & Color $\ldots \ldots \ldots \ldots \ldots \ldots$ & $\begin{array}{l}\text { Good } \\
\text { Fair }\end{array}$ \\
\hline Form & Conspicuous & $\begin{array}{l}\text { Fair } \\
\text { Poor }\end{array}$ \\
\hline Compressed & Inconspicuous & Very poor \\
\hline Conical & $\begin{array}{l}\text { Few } \\
\text { Numerous }\end{array}$ & UsE \\
\hline $\begin{array}{l}\text { Oblate } \\
\text { Oblong }\end{array}$ & 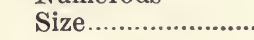 & $\begin{array}{l}\text { USE } \\
\text { Dessert }\end{array}$ \\
\hline $\begin{array}{l}\text { Oblong } \\
\text { Oval }\end{array}$ & & $\begin{array}{l}\text { Dessert } \\
\text { Kitchen }\end{array}$ \\
\hline Round & FLESH & Market \\
\hline $\begin{array}{l}\text { Halves equal } \\
\text { Halves unequal }\end{array}$ & $\begin{array}{l}\text { Green } \\
\text { Red }\end{array}$ & PIT \\
\hline Halves unequal & White & Adhesion \\
\hline Color & Yellow & Cling \\
\hline $\begin{array}{l}\text { Creamy } \\
\text { Green }\end{array}$ & JUICE & $\begin{array}{l}\text { Free } \\
\text { Half free }\end{array}$ \\
\hline Red & Dry & Half free \\
\hline White & Juicy & Size \\
\hline $\begin{array}{l}\text { Yellow } \\
\text { Mottled }\end{array}$ & Color & Large \\
\hline Mottled & $\begin{array}{l}\text { Clear } \\
\text { Dark }\end{array}$ & Medium \\
\hline Cavity & Light & Small \\
\hline Deep & Pink & Shape \\
\hline $\begin{array}{l}\text { Medium } \\
\text { Shallow }\end{array}$ & Texture & Angular \\
\hline $\begin{array}{l}\text { Shallow } \\
\text { Narrow }\end{array}$ & Coarse & $\begin{array}{l}\text { Flattened } \\
\text { Necked }\end{array}$ \\
\hline Wide & Crisp & \\
\hline & Firm & Obovate \\
\hline & Fine & Oval \\
\hline $\begin{array}{l}\text { A mere line } \\
\text { Indistinct }\end{array}$ & Melting & Ovate \\
\hline $\begin{array}{l}\text { Indistinct } \\
\text { Lacking }\end{array}$ & $\begin{array}{l}\text { Stringy } \\
\text { Tender }\end{array}$ & Plump \\
\hline & $\begin{array}{l}\text { Tender } \\
\text { Medium }\end{array}$ & Blunt \\
\hline Continuous & Tough & $\begin{array}{l}\text { Pointed } \\
\text { Prolonged }\end{array}$ \\
\hline Deep & & Roundish \\
\hline Shallow & Flavor & Winged \\
\hline APEX & $\begin{array}{l}\text { Flat } \\
\text { Mild }\end{array}$ & Surface \\
\hline Depressed & Sour & Pitted \\
\hline Flattened & Sweet & Rough \\
\hline Pointed & Sub-acid & Smooth \\
\hline & {$[190]$} & \\
\hline
\end{tabular}




\section{A STUDY OF THE PEACH}

Season

LOCALITY

Productivenfss

General Appearance.

DesirabiLITY

Histor Y

REMARKS

Draw a longitudinal section of the fruit and make a drawing of the seed. 


\section{EXERCISE LXIV}

\section{A STUDY OF THE PEACH}

(Underscore or star the terms that apply to the variety of fruit being studied)

VARIETY

DATE.

Group

SYNONYMS

\section{Size}

Large

Medium

Small

\section{ForM}

Compressed

Conical

Oblate

Oblong

Oval

Round

Halves equal

Halves unequal

\section{Color}

Creamy

Green

Red

White

Yellow

Mottled

\section{Cavity \\ Deep \\ Medium \\ Shallow \\ Narrow \\ Wide}

\section{Suture}

A mere line

Indistinct

Lacking

Prominent

Continuous

Deep

Shallow

\section{Apex}

Depressed

Flattened

Pointed
Prolonged tip

Roundish

\section{Dots}

Color.

Conspicuous

Inconspicuous

Few

Numerous

Size

Flesh

Green

Red

White

Yellow

Juice

Dry

Juicy

Color

Clear

Dark

Light

Pink

Texture

Coarse

Crisp

Firm

Fine

Melting

Stringy

Tender

Medium

Tough

Flavor

Flat

Mild

Sour

Sweet

Sub-acid

[192]
Quality

Best

Very good

Good

Fair

Poor

Very poor

UsE

Dessert

Kitchen

Market

PIT

Adhesion

Cling

Free

Half free

Size

Large

Medium

Small

Shape

Angular

Flattened

Necked

Oblique

Obovate

Oval

Ovate

Plump

Blunt

Pointed

Prolonged

Roundish

Winged

Surface

Pitted

Rough

Smooth 
A STUDY OF THE PEACH

Season

LOCALITY

Pronuctivenfiss

General Appearance

Desirability

HISTORY

REMARKS

Draw a longitudinal section of the fruit and make a drawing of the seed. 


\section{EXERCISE LXV}

\section{A STUDY OF THE PEACH}

(Underscore or star the terms that apply to the variety of fruit being studied)

VARIETY

DATE

GrovP

SYNONYMS

Size

Large

Medium

Small

Form

Compressed

Conical

Oblate

Oblong

Oval

Round

Halves equal

Halves unequal

Color

Creamy

Green

Red

White

Yellow

Mottled

Cavity

Deep

Medium

Shallow

Narrow

Wide

\section{Suture}

A mere line

Indistinct

Lacking

Prominent

Continuous

Deep

Shallow

Apex

Depressed

Flattened

Pointed
Prolonged tip

Roundish

Dots

Color.

Conspicuous

Inconspicuous

Few

Numerous

Size.

Flesh

Green

Red

White

Yellow

Juice

Dry

Juicy

Color

Clear

Dark

Light

Pink

Texture

Coarse

Crisp

Firm

Fine

Melting

Stringy

Tender

Medium

Tough

Flavor

Flat

Mild

Sour

Sweet

Sub-acid
Quality

Best

Very good

Good

Fair

Poor

Very poor

Use

Dessert

Kitchen

Market

PIT

Adhesion

Cling

Free

Half free

Size

Large

Medium

Small

Shape

Angular

Flattened

Necked

Oblique

Obovate

Oval

Ovate

Plump

Blunt

Pointed

Prolonged

Roundish

Winged

Surface

Pitted

Rough

Smooth 


\section{A STUDY OF THE PEACH}

\section{SEASON}

LOCALITY

Productiveness

Greneral Appearance

DESIRABILITY

HISTORY

REMARKS

Draw a longitudinal section of the fruit and make a drawing of the seed. 


\section{EXERCISE LXVI}

\section{A STUDY OF THE PEACH}

(Underscore or star the terms that apply to the variety of fruit being studied)

VARIETY

DATE

Group

SyNoNyMS

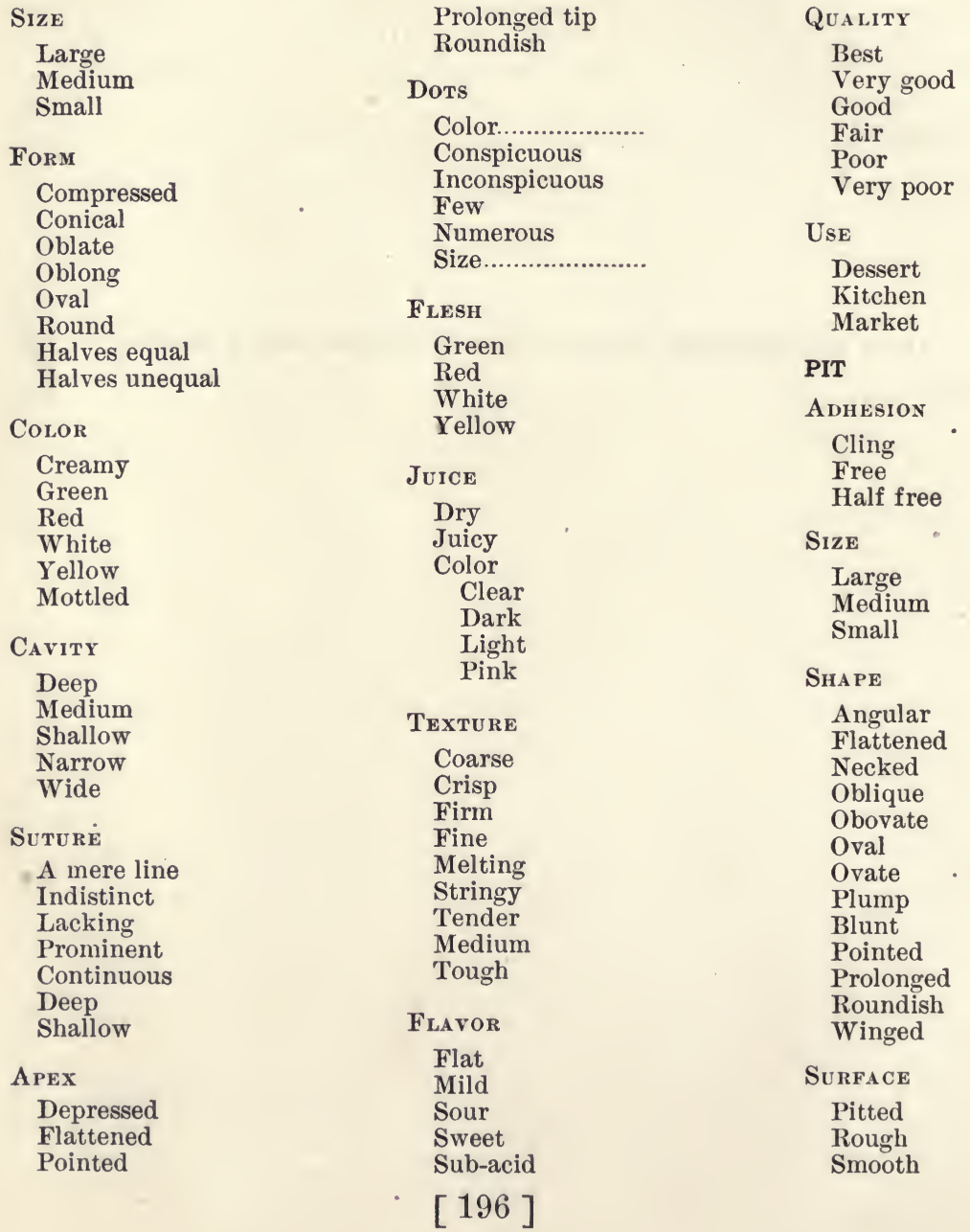




\section{A STUDY OF THE PEACH}

Seasor

LOCALITY

Prodectiveness

Gexeral Appearance

DESIRABILITY

HistoR Y

REMARKS

Draw a longitudinal section of the fruit and make a drawing of the seed. 


\section{EXERCISE LXVII}

\section{A STUDY OF THE PEAR}

(Underscore or star the terms that apply to the variety of fruit being studied)

VARIETY

DATE

Group

SYNONYMS

\begin{tabular}{|c|c|c|c|}
\hline Size & Color & Tough & Stament \\
\hline Large & Ground..... & Waxen & Basal \\
\hline Medium & Overlying & Core & Marginal \\
\hline Small & Blushed & Abaxile & Medial \\
\hline ForM & Striped & Axile & $\begin{array}{l}\text { CARPELS } \\
\text { Cordate }\end{array}$ \\
\hline Acute & 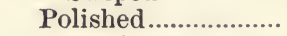 & Large & $\begin{array}{l}\text { Cordate } \\
\text { Emarginate }\end{array}$ \\
\hline Irregular & Prevailing effect..... & Medium & Ovate \\
\hline Oblong & CALYX & Closed & Round \\
\hline Obovate & Closed & Open & Tufted \\
\hline Ovate & Open & Distant & SEED \\
\hline Pyriform & Large & Medial & Acuminate \\
\hline Ribbed & Medium & Sessile & Acute \\
\hline Roundish & Small & Core Luve & Flat \\
\hline Sides unequal & Calyx Lobes & CORE LINE & Large \\
\hline Symmetrical & Acuminate & Clasping & Long \\
\hline Turbinate & Acute & Meeting & Medium \\
\hline & Obtuse & Calyx Tube & Narrow \\
\hline NeCK & Long & Conical & Obtuse \\
\hline $\begin{array}{l}\text { Acute } \\
\text { Distinct }\end{array}$ & Medium & Funnel-shaped & $\begin{array}{l}\text { Plump } \\
\text { Small }\end{array}$ \\
\hline $\begin{array}{l}\text { Distinct } \\
\text { Narrow }\end{array}$ & $\begin{array}{l}\text { Short } \\
\text { Narrow }\end{array}$ & Urn-shaped & Tufted \\
\hline $\begin{array}{l}\text { Narrow } \\
\text { Obscure }\end{array}$ & $\begin{array}{l}\text { Narrow } \\
\text { Wide }\end{array}$ & Long & Wide \\
\hline Obtuse & Separated at base & $\begin{array}{l}\text { Short } \\
\text { Narrow }\end{array}$ & Flavor \\
\hline Short & BASIN & Wide & \\
\hline STEM & Abrupt & Dots & $\begin{array}{l}\text { Astringent } \\
\text { Flat }\end{array}$ \\
\hline Long & $\begin{array}{l}\text { Angular } \\
\text { Corrugated }\end{array}$ & Absent & Neutral \\
\hline Medium & Furrowed & Present & Sprightly \\
\hline Short & Obtuse & Flesir & Sour \\
\hline Slender & Symmetrical & Color & Sub-acid \\
\hline Thick & Wrinkled & Color .... & Sweet \\
\hline Cavity & Deep & Texture & $\begin{array}{l}\text { QUALITY } \\
\text { Best }\end{array}$ \\
\hline Acuminate & $\begin{array}{l}\text { Medium } \\
\text { Shallow }\end{array}$ & Buttery & $\begin{array}{l}\text { Best } \\
\text { Very good }\end{array}$ \\
\hline Acute & Narrow & $\begin{array}{l}\text { Coarse } \\
\text { Crisp }\end{array}$ & Good \\
\hline Furrowed & Wide & Dry & Medium \\
\hline Lipped & Skin & Granular & Poor \\
\hline Obtuse & Dull & Fibrous & Very poor \\
\hline Russeted & Glossy & Fine & MARKET \\
\hline Symmetrical & Rough & Firm & Distant \\
\hline Narrow & Russet & Juicy & Local \\
\hline Wide & Smooth & Medium & UsE \\
\hline Deep & Tender & Sweet & Cooking \\
\hline Medium & Thick & Tender & Dessert \\
\hline Shallow & Thin & Tough & Market \\
\hline
\end{tabular}


A STUDY OF THE PEAR

Season

LOCALITY

Productiveness

General Appearance.

Desirabilit Y

HistoR Y

REMARKS

Draw a longitudinal section of the fruit. 


\section{EXERCISE LXVIII}

\section{A STUDY OF THE PEAR}

(Underscore or star the terms that apply to the variety of fruit being studied)

VARIETY

DATE

Group

SyNONYMS

\begin{tabular}{|c|c|c|c|}
\hline SIZE & COLOR & Tough & Stamens \\
\hline Large & Ground ...................... & Waxen & Basal \\
\hline Medium & Overlying & CORE & Marginal \\
\hline Small & Blushed & Abaxile & Medial \\
\hline FORM & Mottled & Axile & Carpels \\
\hline Acute & $\begin{array}{l}\text { Striped } \\
\text { Polished... }\end{array}$ & Large & Cordate \\
\hline $\begin{array}{l}\text { Acute } \\
\text { Irregular }\end{array}$ & Prevailing effect..... & Medium & $\begin{array}{l}\text { Emarginate } \\
\text { Ovate }\end{array}$ \\
\hline Oblong & $\mathrm{C}_{A L Y X}$ & $\begin{array}{l}\text { Small } \\
\text { Closed }\end{array}$ & Round \\
\hline Obovate & Closed & Open & Tufted \\
\hline Ovate & Open & Distant & SEED \\
\hline Pyriform & Large & Medial & Acuminate \\
\hline Ribbed & Medium & Sessile & Acute \\
\hline Roundish & Small & Core Line & Flat \\
\hline Sides unequal & Calyx Lobes & CORE LINE & Large \\
\hline Symmetrical & Acuminate & $\begin{array}{l}\text { Clasping } \\
\text { Meeting }\end{array}$ & Long \\
\hline Turbinate & Acute & & Medium \\
\hline NeCK & Obtuse & Calyx Tube & Narrow \\
\hline Acute & Long & Conical & tuse \\
\hline $\begin{array}{l}\text { Acute } \\
\text { Distinct }\end{array}$ & $\begin{array}{l}\text { Medium } \\
\text { Short }\end{array}$ & Funnel-shaped & Small \\
\hline Narrow & Narrow & Urn-shaped & Tufted \\
\hline $\begin{array}{l}\text { Obscure } \\
\text { Obtuse }\end{array}$ & Wide & Lol & Wide \\
\hline $\begin{array}{l}\text { Obtuse } \\
\text { Short }\end{array}$ & Separated at base & Narrow & Flavor \\
\hline Short & BASIN & Wide & Aromatic \\
\hline STEM & Abrupt & Dots & $\begin{array}{l}\text { Astr1 } \\
\text { Flat }\end{array}$ \\
\hline Long & Corrugated & Absent & Neutral \\
\hline $\begin{array}{l}\text { Medium } \\
\text { Short }\end{array}$ & Furrowed & Present & Sprightly \\
\hline $\begin{array}{l}\text { Short } \\
\text { Slender }\end{array}$ & Obtuse & Flesh & Sour \\
\hline $\begin{array}{l}\text { Slender } \\
\text { Thick }\end{array}$ & $\begin{array}{l}\text { Symmetrical } \\
\text { Wrinkled }\end{array}$ & Color... & $\begin{array}{l}\text { Sub-acid } \\
\text { Sweet }\end{array}$ \\
\hline & Deep & Texture & QUality \\
\hline Cavity & Medium & Buttery & Best \\
\hline Acuminate & Shallow & Coarse & Very good \\
\hline & Narrow & Crisp & \\
\hline Furrowed & $\begin{array}{l}\text { Wide } \\
\text { Skin }\end{array}$ & Dry & $\begin{array}{l}\text { Medium } \\
\text { Poor }\end{array}$ \\
\hline $\begin{array}{l}\text { Lipped } \\
\text { Obtuse }\end{array}$ & $\begin{array}{l}\text { Skiv } \\
\text { Dull }\end{array}$ & $\begin{array}{l}\text { Granular } \\
\text { Fibrous }\end{array}$ & Very poor \\
\hline Russeted & Glossy & Fine & MARKET \\
\hline Symmetrical & Rough & Firm & Distant \\
\hline Narrow & Russet & Juic & Local \\
\hline Wide & Smooth & Medium & UsE \\
\hline Deep & Tender & Sweet & Cooking \\
\hline Medium & Thick & & Dessert \\
\hline Shallow & Thin & Tough & Market \\
\hline
\end{tabular}


A STUDY OF THE PEAR

Seasor

LOCALITY

Productiveness

General Appearance

DesirabiLITY

History

REMARKS

Draw a longitudinal section of the fruit. 


\section{EXERCISE LXIX}

\section{A STUDY OF THE PEAR}

(Underscore or star the terms that apply to the variety of fruit being studied)

VARIETY

DATE

Group

SYNONYMS

SizE

Large

Medium

Small

ForM

Acute

Irregular

Oblong

Obovate

Ovate

Pyriform

Ribbed

Roundish

Sides unequal

Symmetrical

Turbinate

NeCK

Acute

Distinct

Narrow

Obscure

Obtuse

Short

Stem

Long

Medium

Short

Slender

Thick

Cavity

Acuminate

Acute

Furrowed

Lipped

Obtuse

Russeted

Symmetrical

Narrow

Wide

Deep

Medium

Shallow

Color
Ground .....................
Overlying
Blushed
Mottled
Striped
Polished.................
Prevailing effect.....

CALYX

Closed

Open

Large

Medium

Small

Calyx Lobes

Acuminate

Acute

Obtuse

Long

Medium

Short

Narrow

Wide

Separated at base

BASIN

Abrupt

Angular

Corrugated

Furrowed

Obtuse

Symmetrical

Wrinkled

Deep

Medium

Shallow

Narrow

Wide

SkIN

Dull

Glossy

Rough

Russet

Smooth

Tender

Thick

Thin
Tough

Waxen

Core

Abaxile

Axile

Large

Medium

Small

Closed

Open

Distant

Medial

Sessile

Core Line

Clasping

Meeting

Calyx Tube

Conical

Funnel-shaped

Urn-shaped

Long

Short

Narrow

Wide

Dots

Absent

Present

Flesh

Color.

Texture

Buttery

Coarse

Crisp

Dry

Granular

Fibrous

Fine

Firm

Juicy

Medium

Sweet

Tender

Tough
Stamens

Basal

Marginal

Medial

Carpels

Cordate

Emarginate

Ovate

Round

Tufted

SeEd

Acuminate

Acute

Flat

Large

Long

Medium

Narrow

Obtuse

Plump

Small

Tufted

Wide

Flavor

Aromatic

Astringent

Flat

Neutral

Sprightly

Sour

Sub-acid

Sweet

QUALITY

Best

Very good

Good

Medium

Poor

Very poor

MARKET

Distant

Local

UsE

Cooking

Dessert

Market 
A STUDY OF THE PEAR

SeAson

LOCALITY

Productiveness

General Appearance:

DesirabiLity

HistoRY

REMARKS

Draw a longitudinal section of the fruit. 


\section{EXERCISE LXX}

\section{A STUDY OF THE PEAR}

(Underscore or star the terms that apply to the variety of fruit being studied)

VARIETY

DATE

Group

SyNONYMS

\begin{tabular}{|c|c|c|c|}
\hline Size & Color & Tough & Stamens \\
\hline Large & Ground..... & Waxen & Basal \\
\hline Medium & Overlying & Core & Marginal \\
\hline Small & $\begin{array}{l}\text { Blushed } \\
\text { Mottled }\end{array}$ & Abaxile & Medial \\
\hline FORM & $\begin{array}{l}\text { Mottled } \\
\text { Striped }\end{array}$ & Axile & CARPELS \\
\hline Acute & Polished .................... & Large & Cordate \\
\hline Irregular & Prevailing effect..... & $\begin{array}{l}\text { Medium } \\
\text { Small }\end{array}$ & $\begin{array}{l}\text { Emarginate } \\
\text { Ovate }\end{array}$ \\
\hline Oblong & CALYX & Closed & Round \\
\hline Obovate & Closed & Open & Tufted \\
\hline Ovate & Open & Distant & SEED \\
\hline Pyriform & Large & Medial & Acuminate \\
\hline Ribbed & Medium & Sessile & Acute \\
\hline Roundish & Small & Core Line & Flat \\
\hline Sides unequal & $\begin{array}{c}\text { Calyx Lobes } \\
\text { Acuminate }\end{array}$ & Clasping & $\begin{array}{l}\text { Large } \\
\text { Long }\end{array}$ \\
\hline $\begin{array}{l}\text { Symmetrical } \\
\text { Turbinate }\end{array}$ & $\begin{array}{l}\text { Acuminate } \\
\text { Acute }\end{array}$ & Meeting & $\begin{array}{l}\text { Long } \\
\text { Medium }\end{array}$ \\
\hline NeCK & Obtuse & Calyx Tube & Narrow \\
\hline $\begin{array}{l}\text { NeCK } \\
\text { Acute }\end{array}$ & Long & Conical & Obtuse \\
\hline $\begin{array}{l}\text { Acute } \\
\text { Distinct }\end{array}$ & Medium & Funnel-shaped & Plump \\
\hline $\begin{array}{l}\text { Distinct } \\
\text { Narrow }\end{array}$ & $\begin{array}{l}\text { Short } \\
\text { Narrow }\end{array}$ & Urn-shaped & $\begin{array}{l}\text { Small } \\
\text { Tufted }\end{array}$ \\
\hline $\begin{array}{l}\text { Narrow } \\
\text { Obscure }\end{array}$ & $\begin{array}{l}\text { Narrow } \\
\text { Wide }\end{array}$ & Long & Wide \\
\hline Obtuse & Separated at base & $\begin{array}{l}\text { Short } \\
\text { Narrow }\end{array}$ & Flavor \\
\hline Short & BASIN & Wide & Aromatic \\
\hline Stem & $\begin{array}{l}\text { Abrupt } \\
\text { Angular }\end{array}$ & Dots & $\begin{array}{l}\text { Astringent } \\
\text { Flat }\end{array}$ \\
\hline Long & Corrugated & Absent & Neutral \\
\hline Medium & Furrowed & Present & Sprightly \\
\hline Short & Obtuse & FLESH & Sour \\
\hline Slender & Symmetrical & Color..... & Sub-acid \\
\hline Thick & $\begin{array}{l}\text { Wrinkled } \\
\text { Deep }\end{array}$ & Texture & Sweet \\
\hline Cavity & Medium & TeXtuRe & $\begin{array}{l}\text { Quality } \\
\text { Best }\end{array}$ \\
\hline Acuminate & Shallow & $\begin{array}{l}\text { Buttery } \\
\text { Coarse }\end{array}$ & $\begin{array}{l}\text { Best } \\
\text { Very good }\end{array}$ \\
\hline Acute & Narrow & $\begin{array}{l}\text { Coarse } \\
\text { Crisp }\end{array}$ & Good \\
\hline Furrowed & Wide & Dry & Medium \\
\hline Lipped & Skin & Granular & Poor \\
\hline Obtuse & Dull & Fibrous & Very poor \\
\hline Russeted & Glossy & Fine & MARKET \\
\hline Symmetrical & Rough & Firm & Distant \\
\hline Narrow & Russet & Juicy & Local \\
\hline Wide & Smooth & Medium & USE \\
\hline Deep & Tender & Sweet & Cooking \\
\hline Medium & Thick & Tender & Dessert \\
\hline Shallow & Thin & Tough & Market \\
\hline
\end{tabular}




\section{A STUDY OF THE PEAR}

SEASON

LOCALITY

Productiveness

General Appearance

DESIRABILITY

HistoRY

REMARKS

Draw a longitudinal section of the fruit. 


\section{EXERCISE LXXI}

\section{A STUDY OF THE PEAR}

(Underscore or star the terms that apply to the variety of fruit being studied)

VARIETY

DATE

GrouP

SYNONYMS

\begin{tabular}{|c|c|c|c|}
\hline Size & Color & Tough & Stamens \\
\hline Large & Ground........ & Waxen & Basal \\
\hline Medium & Overlying & Core & Marginal \\
\hline Small & Blushed & Abaxile & Medial \\
\hline & Mottled & Axile & Carpels \\
\hline Form & $\begin{array}{l}\text { Striped } \\
\text { Polished }\end{array}$ & Large & Cordate \\
\hline Acute & $\begin{array}{l}\text { Polished.................. } \\
\text { Prevailing effect.... }\end{array}$ & Medium & Emarginate \\
\hline $\begin{array}{l}\text { Irregular } \\
\text { Oblong }\end{array}$ & & Small & Ovate \\
\hline Oblong & $\begin{array}{l}\text { CaLYX } \\
\text { Closed }\end{array}$ & Closed & Round \\
\hline Obovate & $\begin{array}{l}\text { Closed } \\
\text { Open }\end{array}$ & Open & Tufted \\
\hline Ovate & Open & Distant & SEED \\
\hline Pyriform & Large & Medial & Acuminate \\
\hline Ribbed & Medium & Sessile & Acute \\
\hline Roundish & Small & Core Line & Flat \\
\hline Sides unequal & Calyx Lobes & & Large \\
\hline $\begin{array}{l}\text { Symmetrical } \\
\text { Turbinate }\end{array}$ & Acuminate & Clasping & Long \\
\hline Turbinate & Acute & Meeting & Medium \\
\hline NeCK & Obtuse & Calyx Tube & Narrow \\
\hline NECK & Long & Conical & $\begin{array}{l}\text { Obtuse } \\
\text { Plump }\end{array}$ \\
\hline $\begin{array}{l}\text { Acute } \\
\text { Distinct }\end{array}$ & Medium & Funnel-shaped & Small \\
\hline $\begin{array}{l}\text { Distinct } \\
\text { Narrow }\end{array}$ & $\begin{array}{l}\text { Short } \\
\text { Narrow }\end{array}$ & Urn-shaped & Tufted \\
\hline Obscure & Wide & $\begin{array}{l}\text { Long } \\
\text { Short }\end{array}$ & Wide \\
\hline Obtuse & Separated at base & Narrow & Flavor \\
\hline Short & BASIN & Wide & Aromatic \\
\hline Stem & $\begin{array}{l}\text { Abrupt } \\
\text { Angular }\end{array}$ & Dотs & $\begin{array}{l}\text { Astringent } \\
\text { Flat }\end{array}$ \\
\hline Long & Corrugated & Absent & Neutral \\
\hline Medium & Furrowed & Present & Sprightly \\
\hline Short & Obtuse & FLESH & Sour \\
\hline Slender & Symmetrical & Color..... & Sub-acid \\
\hline Thick & Wrinkled & & Sweet \\
\hline & Deep & Texture & QUALITY \\
\hline Cavity & Medium & Buttery & Best \\
\hline Acuminate & Shallow & Coarse & Very good \\
\hline Acute & Narrow & Crisp & Good \\
\hline Furrowed & Wide & Dry & Medium \\
\hline Lipped & SkIN & Granular & Poor \\
\hline Obtuse & Dull & Fibrous & Very poor \\
\hline Russeted & Glossy & Fine & MARKET \\
\hline Symmetrical & Rough & Firm & Distant \\
\hline Narrow & Russet & Juicy & Local \\
\hline Wide & Smooth & Medium & UsE \\
\hline Deep & Tender & Sweet & Cooking \\
\hline Medium & Thick & Tender & Dessert \\
\hline Shallow & Thin & Tough & Market \\
\hline \multicolumn{4}{|c|}{$[206]$} \\
\hline
\end{tabular}


A STUDY OF THE PEAR

Seasox

LOCALITY

Productiveness

General Appearance.

Desirability

HISTORY.

REMARKS

Draw a longitudinal section of the fruit. 


\section{EXERCISE LXXII}

\section{A STUDY OF THE PEAR}

(Underscore or star the terms that apply to the variety of fruit being studied)

VARIETY

DATE

\section{GROUP}

SyNONYMS

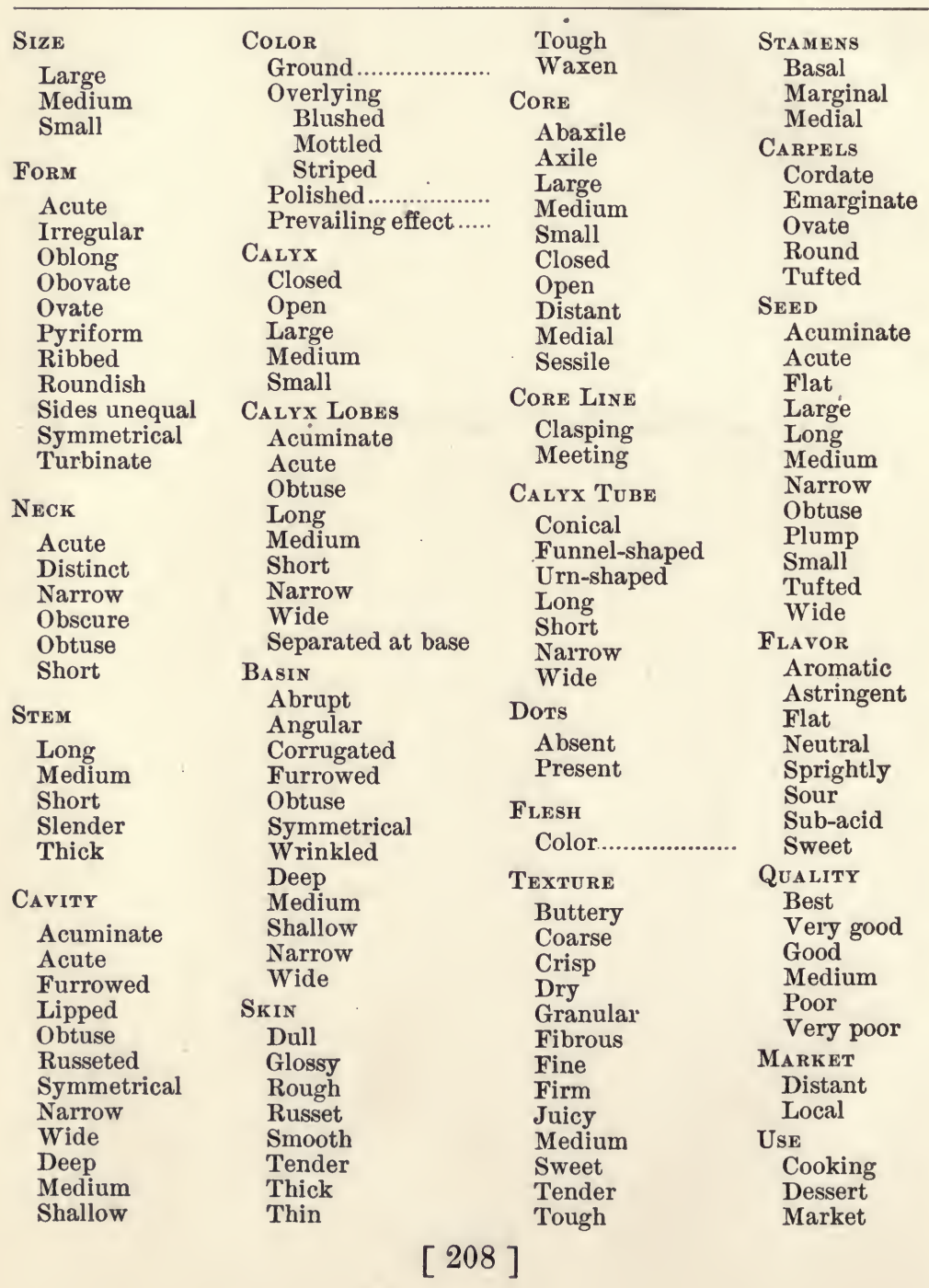


A STUDY OF THE PEAR

\section{Season}

LOCALITY

Productiveness

General Appearance

DesirabiLITY

HISTORY

Remarks

Draw a longitudinal section of the fruit. 


\section{EXERCISE LXXIII}

\section{A STUDY OF THE PLUM}

(Underscore or star the terms that apply to the variety of fruit being studied)

VARIETY

DATE

Group

SYNONYMS

\begin{tabular}{|c|c|c|c|}
\hline SIzE & Pubescent................. & Dots & QUALITY \\
\hline Large & & Few & Best \\
\hline Medium & ANGLE of SteM...... & Many & Very good \\
\hline Small & & Large & Good \\
\hline & Cavity & Small & Fair \\
\hline FORM & Acuminate & Color .................... & Poor \\
\hline Compressed & Acute & Conspicuous......... & Very poor \\
\hline $\begin{array}{l}\text { Conical } \\
\text { Cordate }\end{array}$ & Lipped & Flesh & USE \\
\hline $\begin{array}{l}\text { Coraate } \\
\text { Halves equal }\end{array}$ & Symmetrical & Colorless & Cooking \\
\hline Halves unequal & $\begin{array}{l}\text { Narrow } \\
\text { Wide }\end{array}$ & $\begin{array}{l}\text { Green } \\
\text { Purnle }\end{array}$ & Dessert \\
\hline Necked & Deep & $\begin{array}{l}\text { Purple } \\
\text { Red }\end{array}$ & Market \\
\hline & Medium & White & \\
\hline $\begin{array}{l}\text { Oblong } \\
\text { Oval }\end{array}$ & Shallow & Yellow & PIT \\
\hline Ovate & Suture & JUICE & ADHESION \\
\hline $\begin{array}{l}\text { Pyriform } \\
\text { Roundish }\end{array}$ & A mere line & Dry & Cling \\
\hline $\begin{array}{l}\text { Roundish } \\
\text { Truncate }\end{array}$ & Continuous & Juicy & $\begin{array}{l}\text { Free } \\
\text { Half free }\end{array}$ \\
\hline & Indistinct & Color & \\
\hline Amber & Lacking & Clear & SIzE \\
\hline Amber & Prominent & Dark-colored & Large \\
\hline Black & Deep & Light-colored & Medium \\
\hline Blue & Shallow & Pink & Small \\
\hline Crimson & & Texture & Shape \\
\hline $\begin{array}{l}\text { Mottled } \\
\text { Purple }\end{array}$ & Apex & Coarse & NHATE \\
\hline Red & Depressed & Crisp & $\begin{array}{l}\text { Angular } \\
\text { Blunt }\end{array}$ \\
\hline White & $\begin{array}{l}\text { Flattened } \\
\text { Pointed }\end{array}$ & Fine-grained & Flattened \\
\hline Yellow & $\begin{array}{l}\text { Pointed } \\
\text { Prolonged tip }\end{array}$ & $\begin{array}{l}\text { Firm } \\
\text { Melting }\end{array}$ & Necked \\
\hline BLOOM & Roundish & Stringy & Oblique \\
\hline Blue & & Tender & $\begin{array}{l}\text { Obovate } \\
\text { Oval }\end{array}$ \\
\hline $\begin{array}{l}\text { Gray } \\
\text { Lilac }\end{array}$ & SKIN & $\begin{array}{l}\text { Medium } \\
\text { Tough }\end{array}$ & Ovate \\
\hline $\begin{array}{l}\text { Lilac } \\
\text { White }\end{array}$ & Astringent & & Plump \\
\hline Thick & Medium & Flavor & Pointed \\
\hline Thin & $\begin{array}{l}\text { Thick } \\
\text { Thin }\end{array}$ & Aromatic & Prolonged at \\
\hline & Tender & $\begin{array}{l}\text { Astringent } \\
\text { Flat }\end{array}$ & $\begin{array}{l}\text { ends } \\
\text { Roundish }\end{array}$ \\
\hline $\begin{array}{l}\text { STEM } \\
\text { Slender }\end{array}$ & Tough & Mild & Winged \\
\hline $\begin{array}{l}\text { Slender } \\
\text { Medium }\end{array}$ & Translucent & Sour & SURFACE \\
\hline $\begin{array}{l}\text { Medium } \\
\text { Thick }\end{array}$ & $\begin{array}{l}\text { Adherence to } \\
\text { flesh }\end{array}$ & $\begin{array}{l}\text { Sprightly } \\
\text { Sub-acid }\end{array}$ & Pitted \\
\hline Long & Adherent & Sweet & Rough \\
\hline Short & Free & Tart & Smooth \\
\hline
\end{tabular}




\section{A STUDY OF THE PLUM}

Season

LOCALITY

Productiveness

General Appearance

\section{Desirability}

HISTORY

REMARKS

Draw a longitudinal section of the fruit and a side view of the seed. 


\section{EXERCISE LXXIV}

\section{A STUDY OF THE PLUM}

(Underscore or star the terms that apply to the variety of fruit being studied)

VARIETY

DATE

Group

SyNonyms

\begin{tabular}{|c|c|c|c|}
\hline Size & Pubescent................. & Dots & QUALITY \\
\hline Large & & Few & Best \\
\hline $\begin{array}{l}\text { Medium } \\
\text { Small }\end{array}$ & ANGLE OF STEM...... & $\begin{array}{l}\text { Many } \\
\text { Large }\end{array}$ & Very good \\
\hline & Cavity & Small & $\begin{array}{l}\text { Good } \\
\text { Fair }\end{array}$ \\
\hline FORM & Acuminate & Color ........................ & Poor \\
\hline Compressed & Acute & Conspicuous ......... & Very poor \\
\hline $\begin{array}{l}\text { Conical } \\
\text { Cordate }\end{array}$ & Lipped & Flesh & \\
\hline $\begin{array}{l}\text { Cordate } \\
\text { Halves equal }\end{array}$ & Symmetrical & Colorless & USE \\
\hline Halves unequal & $\begin{array}{l}\text { Narrow } \\
\text { Wide }\end{array}$ & Green & Cooking \\
\hline $\begin{array}{l}\text { Necked } \\
\text { Oblate }\end{array}$ & $\begin{array}{l}\text { Wide } \\
\text { Deep }\end{array}$ & Purple & $\begin{array}{l}\text { Dessert } \\
\text { Market }\end{array}$ \\
\hline $\begin{array}{l}\text { Oblate } \\
\text { Oblong }\end{array}$ & Medium & $\begin{array}{l}\text { Red } \\
\text { White }\end{array}$ & \\
\hline $\begin{array}{l}\text { Oblong } \\
\text { Oval }\end{array}$ & Shallow & Yellow & PIT \\
\hline $\begin{array}{l}\text { Ovate } \\
\text { Pyriform }\end{array}$ & & JUICE & AdHesion \\
\hline $\begin{array}{l}\text { Pyriform } \\
\text { Roundish }\end{array}$ & $\begin{array}{l}\text { SUTURE } \\
\text { A mere line }\end{array}$ & Dry & Cling \\
\hline $\begin{array}{l}\text { Roundish } \\
\text { Truncate }\end{array}$ & $\begin{array}{l}\text { A mere line } \\
\text { Continuous }\end{array}$ & Juicy & Free \\
\hline & Indistinct & CoLor & Half free \\
\hline $\begin{array}{l}\text { Color } \\
\text { Amber }\end{array}$ & Lacking & Clear & Size \\
\hline $\begin{array}{l}\text { Amber } \\
\text { Black }\end{array}$ & Prominent & Dark-colored & Large \\
\hline $\begin{array}{l}\text { Black } \\
\text { Blue }\end{array}$ & Deep & Light-colored & Medium \\
\hline $\begin{array}{l}\text { Blue } \\
\text { Crimson }\end{array}$ & Shallow & Pink & Small \\
\hline Crimson & & Texture & Shape \\
\hline Purple & APEX & $\begin{array}{l}\text { Coarse } \\
\text { Crisp }\end{array}$ & Angular \\
\hline $\begin{array}{l}\text { Red } \\
\text { White }\end{array}$ & $\begin{array}{l}\text { Depressed } \\
\text { Flattened }\end{array}$ & $\begin{array}{l}\text { Fine-grained } \\
\text { Fine }\end{array}$ & Blunt \\
\hline $\begin{array}{l}\text { White } \\
\text { Yellow }\end{array}$ & Pointed & Firm & Flattened \\
\hline & Prolonged tip & Melting & Necked \\
\hline $\begin{array}{r}\text { Bцoом } \\
\text { Blue }\end{array}$ & Roundish & $\begin{array}{l}\text { Stringy } \\
\text { Tender }\end{array}$ & $\begin{array}{l}\text { Oblique } \\
\text { Obovate }\end{array}$ \\
\hline Blue & Skin & Medium & Oval. \\
\hline $\begin{array}{l}\text { Lilac } \\
\text { White }\end{array}$ & Astringent & Tough & Ovate \\
\hline $\begin{array}{l}\text { White } \\
\text { Thick }\end{array}$ & Medium & Flavor & Pointed \\
\hline $\begin{array}{l}\text { Thick } \\
\text { Thin }\end{array}$ & Thick & Aromatic & Prolonged \\
\hline Stem & Thin & Astringent & ends \\
\hline $\begin{array}{l}\text { STEM } \\
\text { Slender }\end{array}$ & $\begin{array}{l}\text { 1ender } \\
\text { Tough }\end{array}$ & $\begin{array}{l}\text { Flat } \\
\text { Mild }\end{array}$ & $\begin{array}{l}\text { Roundish } \\
\text { Winged }\end{array}$ \\
\hline $\begin{array}{l}\text { Slender } \\
\text { Medium }\end{array}$ & Translucent & Sour & Surnor \\
\hline $\begin{array}{l}\text { Medium } \\
\text { Thick }\end{array}$ & Adherence to & Sprightly & SuRface \\
\hline Thick & flesh & Sub-acid & Pitted \\
\hline $\begin{array}{l}\text { Long } \\
\text { Short }\end{array}$ & Adherent & Sweet & Rough \\
\hline Short & Free & Tart & Smooth \\
\hline
\end{tabular}




\section{A STUDY OF THE PLUM}

Season

LOCALITY

Productiveness

General Appearance.

DESIRA BILITY

History

REMARKS

Draw a longitudinal section of the fruit and a side view of the seed. 


\section{EXERCISE LXXV}

\section{A STUDY OF THE PLUM}

(Underscore or star the terms that apply to the variety of fruit being studied)

VARIETY

DATE

GroUP

SyNONYMS

\begin{tabular}{|c|c|c|c|}
\hline Size & Pubescent............... & Dots & QUALITY \\
\hline Large & & Few & Best \\
\hline Medium & Angle of Stem...... & Many & Very good \\
\hline Small & & Large & Good \\
\hline & Cavity & Small & Fair \\
\hline ForM & Acuminate & Color ................... & Poor \\
\hline Compressed & Acute & Conspicuous......... & Very poor \\
\hline Conical & Lipped & Flesh & UsE \\
\hline $\begin{array}{l}\text { Cordate } \\
\text { Halves equal }\end{array}$ & Symmetrical & Colorless & Conkino \\
\hline Halves unequal & $\begin{array}{l}\text { Narrow } \\
\text { Wide }\end{array}$ & Green & Cooking \\
\hline Necked & $\begin{array}{l}\text { Wide } \\
\text { Deep }\end{array}$ & Purple. & $\begin{array}{l}\text { Dessert } \\
\text { Market }\end{array}$ \\
\hline Oblate & Medium & $\begin{array}{l}\text { Red } \\
\text { White }\end{array}$ & \\
\hline $\begin{array}{l}\text { Oblong } \\
\text { Oval }\end{array}$ & Shallow & Yellow & PIT \\
\hline Ovate & Suture & JUICE & ADHESION \\
\hline Pyriform & A mere line & Dry & Cling \\
\hline $\begin{array}{l}\text { Roundish } \\
\text { Truncate }\end{array}$ & $\begin{array}{l}\text { A mere line } \\
\text { Continuous }\end{array}$ & Juicy & Free \\
\hline 1 runcate & Indistinct & Color & \\
\hline Color & Lacking & Clear & Size \\
\hline Amber & Prominent & Dark-colored & Large \\
\hline Black & Deep & Light-colored & Medium \\
\hline Blue & Shallow & Pink & Small \\
\hline Crimson & & Texture & Shape \\
\hline Mottled & APEX & Coarse & $\begin{array}{l}\text { SHAPE } \\
\text { Angular }\end{array}$ \\
\hline $\begin{array}{l}\text { Purple } \\
\text { Red }\end{array}$ & Depressed & Crisp & Angular \\
\hline $\begin{array}{l}\text { Red } \\
\text { White }\end{array}$ & Flattened & Fine-grained & Blunt \\
\hline Yellow & Pointed & Firm & Flattened \\
\hline & Prolonged tip & Melting & $\begin{array}{l}\text { Necked } \\
\text { Oblique }\end{array}$ \\
\hline $\begin{array}{r}\text { BцоOм } \\
\text { Blue }\end{array}$ & Roundish & $\begin{array}{l}\text { Stringy } \\
\text { Tender }\end{array}$ & Obovate \\
\hline Brae & Skin & Medium & Oval \\
\hline Lilac & Astringent & Tough & $\begin{array}{l}\text { Ovate } \\
\text { Plump }\end{array}$ \\
\hline White & Medium & Flavor & Pointed \\
\hline Thick & Thick & Aromatic & Prolonged at \\
\hline Thin & Thin & Astringent & ends \\
\hline Stem & Tender & Flat & Roundish \\
\hline & Tough & Mild & Winged \\
\hline $\begin{array}{l}\text { Slender } \\
\text { Medium }\end{array}$ & Translucent & Sour & Surface \\
\hline Thick & $\begin{array}{l}\text { Adnerence to } \\
\text { flesh }\end{array}$ & $\begin{array}{l}\text { Sprightly } \\
\text { Sub-acid }\end{array}$ & Pitted \\
\hline Long & Adherent & Sweet & Rough \\
\hline Short & Free & Tart & Smooth \\
\hline
\end{tabular}




\section{A STUDY OF THE PLUM}

Season

LOCALITY

Productiveness

General Appearance

Desirability

History

REMARKS

Draw a longitudinal section of the fruit and a side view of the seed. 


\section{EXERCISE LXXVI}

\section{A STUDY OF THE PLUM}

(Underscore or star the terms that apply to the variety of fruit being studied)

VARIETY

DATE

Group

SyNONYMS

\begin{tabular}{|c|c|c|c|}
\hline Size & Pubescent.................. & Dots & QUALITY \\
\hline Large & & Few & Best \\
\hline Medium & ANGLE OF STEM...... & Many & Very good \\
\hline Small & Cavity & $\begin{array}{l}\text { Large } \\
\text { Small }\end{array}$ & $\begin{array}{l}\text { Good } \\
\text { Fair }\end{array}$ \\
\hline ForM & Acuminate & Color .................... & Poor \\
\hline Compressed & Acute & Conspicuous ......... & Very poor \\
\hline Conical & Lipped & FLesh & UsE \\
\hline $\begin{array}{l}\text { Cordate } \\
\text { Halves equal }\end{array}$ & Symmetrical & Colorless & \\
\hline $\begin{array}{l}\text { Halves equal } \\
\text { Halves unequal }\end{array}$ & $\begin{array}{l}\text { Narrow } \\
\text { Wide }\end{array}$ & Green & Cooking \\
\hline Necked & Deep & Purple & $\begin{array}{l}\text { Dessert } \\
\text { Market }\end{array}$ \\
\hline Oblate & Medium & $\begin{array}{l}\text { Red } \\
\text { White }\end{array}$ & \\
\hline $\begin{array}{l}\text { Oblong } \\
\text { Oval }\end{array}$ & Shallow & Yellow & PIT \\
\hline Ovate & & JUICE & Adhesion \\
\hline $\begin{array}{l}\text { Pyriform } \\
\text { Roundish }\end{array}$ & SUTURE & Dry & Cling \\
\hline $\begin{array}{l}\text { Roundish } \\
\text { Truncate }\end{array}$ & $\begin{array}{l}\text { A mere line } \\
\text { Continuous }\end{array}$ & Juicy & Free \\
\hline Truncate & Indistinct & Color & Half free \\
\hline Color & Lacking & Clear & Size \\
\hline Amber & Prominent & Dark-colored & Large \\
\hline $\begin{array}{l}\text { Black } \\
\text { Blue }\end{array}$ & Deep & Light-colored & Medium \\
\hline $\begin{array}{l}\text { Blue } \\
\text { Crimson }\end{array}$ & Shallow & Pink & Small \\
\hline $\begin{array}{l}\text { Crimson } \\
\text { Mottled }\end{array}$ & & Texture & Shape \\
\hline $\begin{array}{l}\text { Purple } \\
\text { Red }\end{array}$ & APEX & $\begin{array}{l}\text { Coarse } \\
\text { Crisp }\end{array}$ & Angular \\
\hline $\begin{array}{l}\text { Red } \\
\text { White }\end{array}$ & $\begin{array}{l}\text { Depressed } \\
\text { Flattened }\end{array}$ & $\begin{array}{l}\text { Crisp } \\
\text { Fine-grained }\end{array}$ & Blunt \\
\hline $\begin{array}{l}\text { White } \\
\text { Yellow }\end{array}$ & Pointed & Firm & Flattened \\
\hline Jenow & Prolonged tip & Melting & Necked \\
\hline Bцоом & Roundish & Stringy & $\begin{array}{l}\text { Oblique } \\
\text { Obovate }\end{array}$ \\
\hline $\begin{array}{l}\text { Blue } \\
\text { Gray }\end{array}$ & SkIN & $\begin{array}{l}\text { Tender } \\
\text { Medium }\end{array}$ & Oval \\
\hline $\begin{array}{l}\text { Gray } \\
\text { Lilac }\end{array}$ & DKIN & Tough & Ovate \\
\hline $\begin{array}{l}\text { Lilac } \\
\text { White }\end{array}$ & $\begin{array}{l}\text { Astringent } \\
\text { Medium }\end{array}$ & Flavor & Plump \\
\hline Thick & Thick & Aromatic & Prolonged at \\
\hline Thin & Thin & Astringent & ends \\
\hline STEM & Tender & Flat & Roundish \\
\hline $\begin{array}{l}\text { STEM } \\
\text { Slender }\end{array}$ & Tough & Mild & Winged \\
\hline $\begin{array}{l}\text { Slender } \\
\text { Medium }\end{array}$ & $\begin{array}{l}\text { Translucent } \\
\text { Adherence to }\end{array}$ & $\begin{array}{l}\text { Sour } \\
\text { Sprightly }\end{array}$ & Surface \\
\hline Thick & flesh & Sub-acid & Pitted \\
\hline Long & Adherent & Sweet & Rough \\
\hline Short & Free & Tart & Smooth \\
\hline
\end{tabular}




\section{A STUDY OF THE PLUM}

SEASON

LOCALITY

Productiveness

General Appearance:

DEsira BILITY

HISTORY

REMARKS

Draw a longitudinal section of the fruit and a side view of the seed. 


\section{EXERCISE LXXVII}

\section{A STUDY OF THE PLUM}

(Underscore or star the terms that apply to the variety of fruit being studied)

VARIETY

DATE

Grour

SYNONYMS

\begin{tabular}{|c|c|c|c|}
\hline SIZE & Pubescent.................. & Dots & QuaLity \\
\hline Large & & Few & Best \\
\hline Medium & ANgle of Stem...... & Many & Very good \\
\hline Small & & Large & Good \\
\hline Form & Cavity & $\begin{array}{l}\text { Small } \\
\text { Color }\end{array}$ & Fair \\
\hline Compressed & $\begin{array}{l}\text { Acuminate } \\
\text { Acute }\end{array}$ & 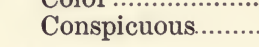 & $\begin{array}{l}\text { Poor } \\
\text { Very poor }\end{array}$ \\
\hline Conical & Lipped & FLESH & \\
\hline Cordate & Symmetrical & Colorless & UsE \\
\hline Halves equal & Narrow & Green & Cooking \\
\hline $\begin{array}{l}\text { Halves unequal } \\
\text { Necked }\end{array}$ & Wide & Purple & Dessert \\
\hline $\begin{array}{l}\text { Necked } \\
\text { Oblate }\end{array}$ & $\begin{array}{l}\text { Deep } \\
\text { Medium }\end{array}$ & Red & Market \\
\hline Oblong & $\begin{array}{l}\text { Medium } \\
\text { Shallow }\end{array}$ & White & PIT \\
\hline $\begin{array}{l}\text { Oval } \\
\text { Ovate }\end{array}$ & & Juice & AdHesion \\
\hline Pyriform & SUture & Dry & Cling \\
\hline $\begin{array}{l}\text { Roundish } \\
\text { Truncate }\end{array}$ & A mere line & Juicy & Free \\
\hline Truncate & $\begin{array}{l}\text { Continuous } \\
\text { Indistinct }\end{array}$ & Color & Half free \\
\hline Color & Lacking & Clear & SizE \\
\hline Amber & Prominent & Dark-colored & Large \\
\hline Black & Deep & Light-colored & Medium \\
\hline Blue & Shallow & Pink & Small \\
\hline $\begin{array}{l}\text { Crimson } \\
\text { Mottled }\end{array}$ & & Texture & Shape \\
\hline Purple & $\begin{array}{l}\text { APEX } \\
\text { Denressed }\end{array}$ & $\begin{array}{l}\text { Coarse } \\
\text { Crisp }\end{array}$ & Angular \\
\hline Red & $\begin{array}{l}\text { Depressed } \\
\text { Flattened }\end{array}$ & Fine-grained & Blunt \\
\hline White & $\begin{array}{l}\text { Faatened } \\
\text { Pointed }\end{array}$ & Firm & Flattened \\
\hline Yellow & Prolonged tip & Melting & Necked \\
\hline Bцоом & Roundish & Stringy & $\begin{array}{l}\text { Oblique } \\
\text { Obovate }\end{array}$ \\
\hline Blue & SkIN & Medium & Oval \\
\hline $\begin{array}{l}\text { Gray } \\
\text { Lilac }\end{array}$ & Astringent & Tough & Ovate \\
\hline White & Medium & Flavor & Pointed \\
\hline Thick & Thick & Aromatic & Prolonged at \\
\hline Thin & Thin & Astringent & ends \\
\hline Stem & Tender & Flat & Roundish \\
\hline $\begin{array}{l}\text { STEM } \\
\text { Slender }\end{array}$ & Tough & Mild & Winged \\
\hline $\begin{array}{l}\text { Slender } \\
\text { Medium }\end{array}$ & Translucent & $\begin{array}{l}\text { Sour } \\
\text { Sprightly }\end{array}$ & Surface \\
\hline $\begin{array}{l}\text { Medium } \\
\text { Thick }\end{array}$ & $\begin{array}{l}\text { Adherence to } \\
\text { flesh }\end{array}$ & $\begin{array}{l}\text {-Sprightly } \\
\text { Sub-acid }\end{array}$ & Pitted \\
\hline Long & Adherent & Sweet & Rough \\
\hline Short & Free & Tart & Sinooth \\
\hline
\end{tabular}


Season

LOCALITY

Productiveness

General Appearance

Desirability

History

REMARKS

Draw a longitudinal section of the fruit and a side view of the seed. 


\section{EXERCISE LXXVIII}

\section{A STUDY OF THE PLUM}

(Underscore or star the terms that apply to the variety of fruit being studied)

VARIETY

DATE

Group

SYNONYMS

\begin{tabular}{|c|c|c|c|}
\hline Size & Pubescent................. & Dots & Quality \\
\hline Large & & Few & Best \\
\hline Medium & ANGLE OF STEM...... & $\begin{array}{l}\text { Many } \\
\text { Large }\end{array}$ & Very good \\
\hline Small & Cavity & Small & Good \\
\hline FORM & Acuminate & Color ................ & $\begin{array}{l}\text { Fair } \\
\text { Poor }\end{array}$ \\
\hline Compressed & Acute & Conspicuous.... & Very poor \\
\hline Conical & Lipped & Flesh & USE \\
\hline $\begin{array}{l}\text { Cordate } \\
\text { Halves equal }\end{array}$ & Symmetrical & Colorless & \\
\hline $\begin{array}{l}\text { Halves equal } \\
\text { Halves unequal }\end{array}$ & Narrow & Green & Cooking \\
\hline Necked & $\begin{array}{l}\text { Wide } \\
\text { Deep }\end{array}$ & Purple & $\begin{array}{l}\text { Dessert } \\
\text { Market }\end{array}$ \\
\hline Oblate & Medium & $\begin{array}{l}\text { Red } \\
\text { White }\end{array}$ & \\
\hline $\begin{array}{l}\text { Oblong } \\
\text { Oval }\end{array}$ & Shallow & Yellow & PIT \\
\hline Ovate & Suture & JuICE & ADHESION \\
\hline $\begin{array}{l}\text { Pyriform } \\
\text { Roundish }\end{array}$ & A mere line & Dry & Cling \\
\hline $\begin{array}{l}\text { Roundish } \\
\text { Truncate }\end{array}$ & $\begin{array}{l}\text { A mere line } \\
\text { Continuous }\end{array}$ & Juicy & $\begin{array}{l}\text { Free } \\
\text { Half free }\end{array}$ \\
\hline CoLOR & $\begin{array}{l}\text { Indistinct } \\
\text { Lacking }\end{array}$ & Color & Mall 110e \\
\hline Amber & $\begin{array}{l}\text { Lacking } \\
\text { Prominent }\end{array}$ & Clear & SIZE \\
\hline Black & $\begin{array}{l}\text { Prominent } \\
\text { Deep }\end{array}$ & $\begin{array}{l}\text { Dark-colored } \\
\text { Light-colored }\end{array}$ & Large \\
\hline Blue & Shallow & Pink & $\begin{array}{l}\text { Medium } \\
\text { Small }\end{array}$ \\
\hline $\begin{array}{l}\text { Crimson } \\
\text { Mottled }\end{array}$ & & Texture & SHAPE \\
\hline $\begin{array}{l}\text { Mottled } \\
\text { Purple }\end{array}$ & Apex & Coarse & SHAPE \\
\hline Red & Depressed & Crisp & Angular \\
\hline White & Flattened & Fine-grained & $\begin{array}{l}\text { Blunt } \\
\text { Flattened }\end{array}$ \\
\hline Yellow & $\begin{array}{l}\text { Pointed } \\
\text { Prolonged tip }\end{array}$ & $\begin{array}{l}\text { Firm } \\
\text { Melting }\end{array}$ & \\
\hline BLoom & Roundish & Stringy & Oblique \\
\hline Blue & & Tender & Obovate \\
\hline $\begin{array}{l}\text { Gray } \\
\text { Lilac }\end{array}$ & SkIN & Medium & $\begin{array}{l}\text { Oval } \\
\text { Ovate }\end{array}$ \\
\hline $\begin{array}{l}\text { Lilac } \\
\text { White }\end{array}$ & Astringent & Tough & $\begin{array}{l}\text { Ovate } \\
\text { Plump }\end{array}$ \\
\hline $\begin{array}{l}\text { White } \\
\text { Thick }\end{array}$ & Medium & Flavor & Pointed \\
\hline $\begin{array}{l}\text { Thick } \\
\text { Thin }\end{array}$ & Thick & Aromatic & Prolonged at \\
\hline Thin & Thin & Astringent & ends \\
\hline STEM & Tender & Flat & Roundish \\
\hline Slender & $\begin{array}{l}\text { Tough } \\
\text { Translucent }\end{array}$ & $\begin{array}{l}\text { Mild } \\
\text { Sour }\end{array}$ & Winged \\
\hline Medium & Adherence to & Sprightly & SuRface \\
\hline Thick & flesh & Sub-acid & Pitted \\
\hline Long & Adherent & Sweet & Rough \\
\hline Short & Free & Tart & Smooth \\
\hline
\end{tabular}




\section{A STUDY OF THE PLUM}

Season

Locality

Productiveness

General Appearance.

Desirability

History

ReMaRKS

Draw a longitudinal section of the fruit and a side view of the seed. 



\section{GLOSSARY}

\section{DESCRIPTIVE TERMS}

This list is intended to cover most of the important terms which might be confusing to the student. Several general terms used in describing fruit are listed first, and the remaining terms follow in alphabetical order under the various headings.

\section{General Terms}

Acute. Tapering nearly to a point.

Apex. A term understood as applying to the part most remote from the branch or root. (In pears, this part is usually spoken of as the crown.) Axis. A line connecting the base and the apex. A longitudinal section of a fruit is made by cutting it from base to apex; a cross, or transverse, section is made by cutting it at right angles to the axis.

Base (of a fruit). The portion toward the branch or root.

Compressed. With the sides flattened, as in some plums.

Depressed. Sunken, as the apex of peaches.

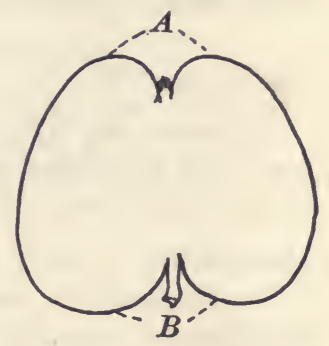

Furrowed (of fruit). More or less regularly Fig. 38. $A$, apex; $B$, base channeled.

Irregular. A term applied to an outline that is elliptical or angular.

Obtuse. Blunt; approximating an obtuse angle.

Pit. A term applied to the seed found in drupaceous fruits.

Regular. When a section through the equatorial diameter shows nearly a circular outline, the fruit is said to be regular.

Ribbed. Having large obtuse and rounded ridges.

Symmetrical. Having parts mutually well proportioned; regular.

Truncate. Abruptly flattened at the end, or (of fruit) appearing as though cut squarely across.

\section{BASIN}

The depression in which the calyx is set is technically called the basin, and several terms are used in describing it.

Abrupt basin. A basin in which the sides show a sudden slope.

Corrugated basin. A basin in which the furrows are wrinkled or folded about the calyx lobes.

Mammiform basin. A basin in which peculiar fleshy protuberances occur about the base of the calyx lobes. 


\section{LABORATORY MANUAL OF HORTICULTURE}

Obtuse basin. A basin in which the sides show a very gradual slope.

Regular basin. A basin in which the sides are smooth.

Ridged, ribbed, and furrowed. Terms expressing slightly different degrees of the condition in which depressed lines extend up the sides of the basin.
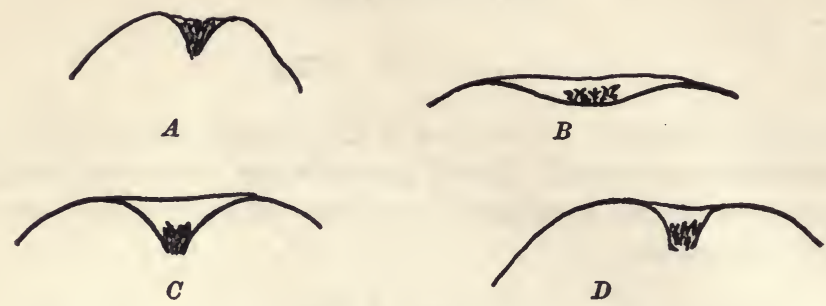

FiG. 39. $A$, narrow basin; $B$, wide basin; $C$, obtuse basin; $D$, abrupt basin

Symmetrical basin. A basin that is nearly round, or uniform in shape. Wavy basin. A basin in which the furrows are indistinct.

\section{CALYX}

The lower part of the flower is called the calyx. The outer green coverings of the flower bud are called the calyx lobes. Calyx lobes remain visible in the mature fruit of some apples, pears, and quinces.

Closed calyx. A calyx whose lobes fold over each other in such a way that the center is completely obscured.

Connivent. A term applied to calyx lobes which are upright and have the tip inclined toward the axis.

Convergent. A term applied to calyx lobes which are flat and inclined toward the axis.

Deciduous. A term applied to calyx lobes which fall away, like those of the Sand Pears and of some pure-Siberian-crab species.

Divergent or reflexed. Terms applied to calyx lobes which turn backward.

Open calyx. A calyx whose lobes flare out in such a way that the center is

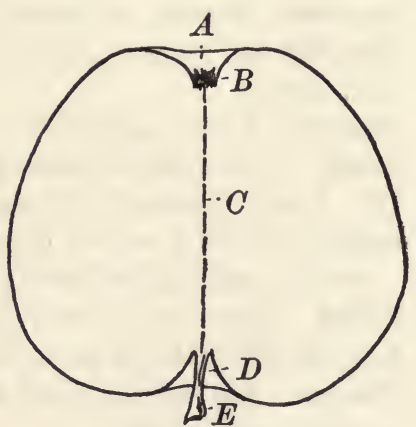

Fig. 40. $A$, basin; $B$, calyx; $C$, axis ; $D$, cavity ; $E$, stem clearly exposed.

Partly open calyx. A calyx whose condition is intermediate between the open and the closed state.

Persistent calyx. A calyx whose lobes remain attached to the fruit, as in some apples, pears, and quinces.

In examining different specimens of the same variety of a species we often find great variation in the above features. 


\section{GLOSSARY}

\section{Calyx Tube}

We recognize three kinds, or shapes, of calyx tubes; namely, the coneshaped, the funnel-shaped, and the urn-shaped.

Cone-shaped calyx tube. A calyx tube resembling, or conforming to, the general shape of a cone.

Funnel-shaped calyx tube. A calyx tube whose general shape resembles that of a funnel, or which has a little tube attached to the base of the cone-shaped tube.

Urn-shaped calyx tube. A calyx tube resembling an urn in shape, or having sides which are neither straight nor funnel-form, but which have a double curve and are comparatively broad and rounded toward the base.

\section{Cavity}

The depression around the stem of a fruit is technically called the cavity.

Acuminate cavity. A cavity in which the stem meets the side of the cavity in a sharp, narrow angle.

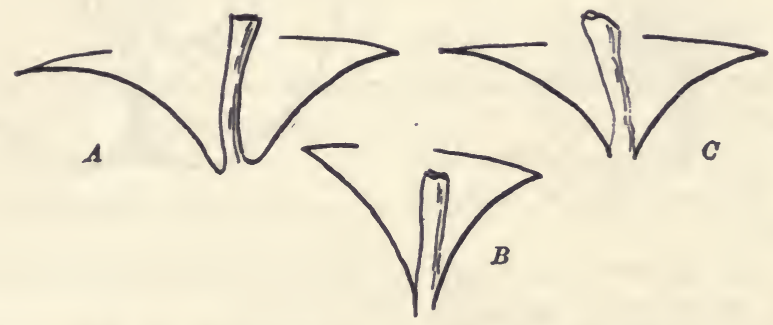

Fra. 41. $A$, obtuse cavity ; $B$, acuminate cavity ;

$C$, acute cavity

Acute cavity. A cavity intermediate between an acuminate and an obtuse cavity, as in the Canada Red apple.

Obtuse cavity. A cavity in which the angle between the stem and the side is wide and blunt, as in the Rome Beauty apple.

In addition to the above we speak of the cavity as being wide or narrow, and deep, medium, or shallow.

\section{Color}

The color of fruit is quite varied and ranges from the light yellow of the white fruits, through the various shades of red, into deep purple. This condition can better be explained by several examples. Thus, we have the white flesh of the snow peach, followed by pale yellows shading gradually into the deeper colors. Again, we find cherries and plums gradually shading from the yellowish tints through to orange and the deeper reds; and the grapes follow with blues, violets, and purples. Amber and fawn with slight mixtures of grays are also found. In addition to solid color in fruits, we find various striped and mottled effects. 


\section{LABORATORY MANUAL OF HORTICULTURE}

Blotched. Having different abrupt shades more or less blended together $\div$ without any order or regularity.

Blushed. Distinguished from mottled, striped, or splashed by having the surface overspread with a red tint that is not much broken.

Clouded. Having blotches broader and more softly shaded and blended together.

Dotted. Having small, distinct dots.

Marbled. Having wide, faint, irregular, or wavy stripes.

Mottled. Covered with dots that run together without any marked lines of distinction.

Scarf skin. A term descriptive of a condition found on fruit (principally on apples), which gives a characteristic appearance to the fruit. It usually extends outward from the base in whitish lines, or stripes, readily distinguished by contrast with the green or yellow color.

Splashed. Having stripes of color which are much broken and of varying widths.

Spotted. Having larger dots than those characterizing a fruit as "dotted."

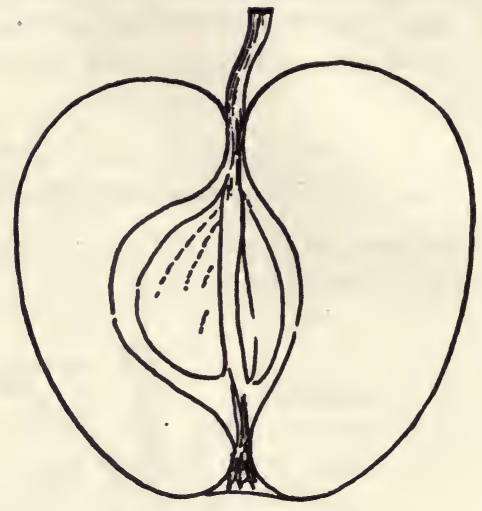

FIG. 42. Abaxile core

Stained. Having the lighter shades of the blotched or clouded effect.

Streaked. Having long and narrow color bands.

Striped. Having one or more shades of color alternating in broad lines.

\section{CORE}

In describing the core, its location in the fruit and the size and character of the carpels and seeds are all considered.

Abaxile. A term used to describe the core when it lies to one side of the axis of the fruit.

Axile. A term used to describe the core when it is equidistant on either side of the axis of the fruit.

Distant. A term used to describe a core which is comparatively far from the stem.

Median. A term used to describe a core which is located at about the center of the fruit.

Sessile. A term used to describe a core which is very close to the stem.

\section{Carpels}

Carpels are the parchmentlike walls of the seed cells. They vary in form somewhat as leaves do, and the terms used in describing leaves may well be applied in describing the carpels. The two sides of the 


\section{GLOSSAR I}

seed cells correspond to the two halves of a leaf, with the axis of the fruit representing the midrib of the leaf.

Cordate. A term used to describe a carpel whose two halves are heartshaped.

Emarginate. A term used to describe carpels which are indented at the top or bottom, but too narrow to be cordate.

Mucronate. A term used to describe carpels which come to a sharp point.

Obcordate. Reversed cordate.

Round. A term used to describe a carpel whose two halves are nearly circular.

\section{Core Line}

The core line is that portion of the fleshy part of the apple surrounding the seed cavities. It constitutes part of the core and is limited by visible lines.

Clasping core line. A core line which appears to join the calyx tube somewhat above the base.

Meeting core line. A core line which joins the calyx tube near or at its base.

\section{Dots}

Dots are small, irregular specks found on some fruits. They are described by the following terms :

Areolar. A term used to describe dots which are surrounded by a halo of a, paler or brighter color. The halo is

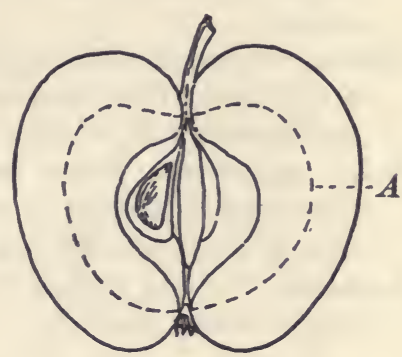

FIg. 43. Axile core

$A$, core line decidedly conspicuous on some varieties and inconspicuous on others. Depressed. A term used to describe dots which are sunken as indicated by touch.

Elongate. A term used to describe dots which are stretched out, or approach the general shape of a rectangle. These dots are often seen on the base of the fruit, along lines radiating from the cavity.

Stellate. A term used to describe dots which approach the form of a star. Submerged. A term used to describe dots which are visible under the epidermis.

\section{FLAVOR}

The flavor of fruit is determined by the acids, sugars, aromatic oils, and other constituents found in the fruit, and it varies slightly with each fruit.

Acid. Possessing a sour taste.

Astringent. Possessing the power of contracting the muscles ; puckery.

Neutral. Neither sweet nor sour, but intermediate between the two.

Perfumed. Possessing pleasing odors.

Spicy. Having an aromatic or fragrant flavor resembling spices.

Vinous. Rich and highly flavored, bordering on acid.

In addition to the above we have sweet, sour, mild, and several other terms that are self-explanatory. 


\section{LABORATORY MANUAL OF HORTICULTURE}

\section{FORM}

The form of a fruit means the shape and is described by the following terms:

Angular. Having sides more or less ribbed.

Conical. Tapering gradually from the base to the apex.

Globose, globular, or round. Terms used to describe fruit which is nearly spherical, as the Fameuse.

Oblate. Flattened, having the height less than the breadth.

Oblique. Having an axis which slants obliquely. This form is sometimes called lopsided.

Oblong. A term used to describe a fruit whose length exceeds its breadth and whose sides are nearly parallel.

Obovate. Reversed ovate; a term used to describe an egg-shaped fruit whose smaller end is at the base instead of at the apex.

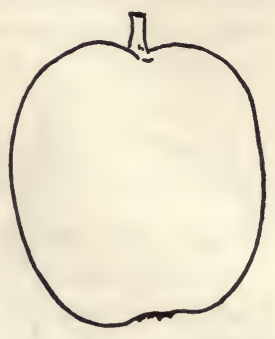

Fig. 44. Oblong

Ovate, egg-shaped. Terms used to describe fruit

whose length somewhat exceeds its breadth, and which has a slightly rounded taper from the base to the apex.

Roundish. Varying slightly from round, or having the length and the breadth nearly equal.

\section{SkIN}

The skin of the different fruits becomes much modified because of the varying conditions under which they are grown. The texture, form, color, and any other characteristics should be noted.

Bloom. A delicate powdery substance, varying in color and found on many fruits. It is seen most frequently on grapes and plums, and occasionally on apples.

Pubescence. Hairiness; a condition sometimes found on the skin of certain fruit. This condition is particularly noticeable on certain portions of the fruit; for example, around the calyx.

Rough skin. A term applied to the surface of fruit when minute capillary russet netted veins or russet dots or both are scattered over the skin.

Russet skin. A condition found on some apples in which all or most of the surface is covered with russet, as seen on the Golden Russet.

Waxy, or oily, skin. Found on some fruits, particularly the apple. This character can best be determined by the sense of touch, the feeling of such a skin much resembling that of a greasy surface.

\section{Size}

Fruits are usually graded into seven sizes as follows: very small, small, medium, below medium, above medium, large, very large.

It is apparent that, owing to the great variation in fruits, no definite line can be drawn between these terms, and they must of necessity be only 


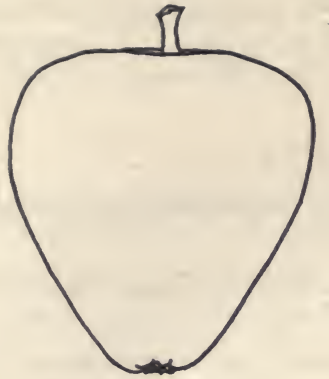

Frg. 45. Conical

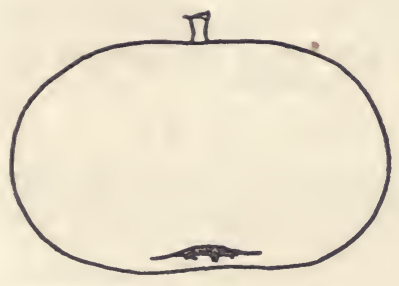

FIg. 47. Oblate

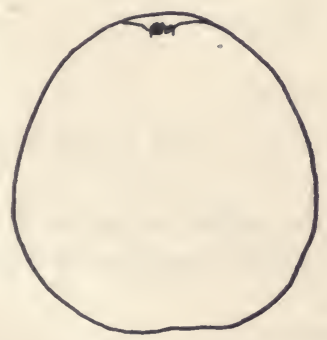

Fig. 49. Ovate

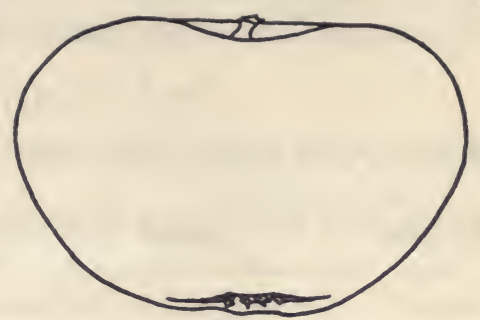

FIG. 46. Oblate-conical

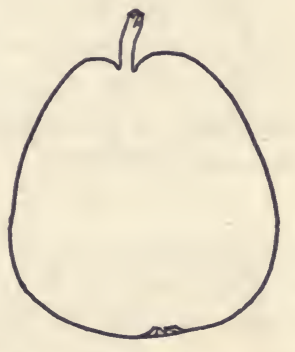

Fig. 48. Obovate

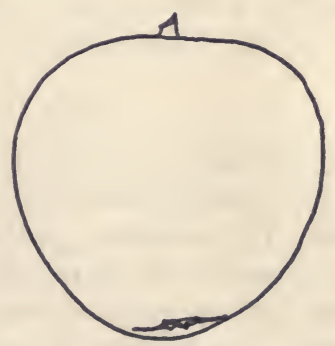

Fig. 50. Round-ovate 


\section{LABORATORY MANUAL OF HORTICULTURE}

comparative. Among apples the crabs are usually referred to as being small or very small, the Jonathan or Baldwin as medium, and the Wolf River as large or very large. The other varieties of apples can be gauged according to these already mentioned.

\section{Stamens}

Basal. A term applied to the stamens when they are located near the base of the calyx tube.

Marginal. A term applied to the stamens when they are located near the outer margin of the calyx tube.

Medial. A term applied to the stamens when they are located about the middle of the calyx tube.

\section{STEM}

The character of the stem is of some importance, although it varies much on different individual fruits of the same variety. Unfortunately, however, there are comparatively few varieties which show a stem so characteristic that the fruit may be recognized by this character alone. In this case, as with the size, the descriptive terms must of necessity only be comparative. We speak of a stem as being long or short, medium, slender, thick, fleshy, or warty. Lipped is a term which signifies that the flesh forms a protuberance, or lip, under which the stem is inserted; for example, the Pewaukee apple.

\section{Suture}

Suture (meaning "seam") is more conspicuous on the stone fruits than on any other class. It is a furrow, or depression, extending from the base to the apex on either one or both sides of the fruit.

Distinct. A term used to describe a suture in which the seam is clear and well defined.

Large. A term used to describe a suture in which the seam is wide and deep.

Obscure. A term used to describe a suture in which the seam is faint or indistinct.

Obsolete. A term used to describe fruit in which the suture either does not exist or exists only as a faint line on the surface.

\section{Special Terms for the Grape}

Foxy. Possessing a sour, unpleasant taste, as found in some grapes which have a coarse flavor, like the fox grapes.

Brush. The bristlelike portion left attached to the pedicel when the berry is removed; the central portion of the berry, which usually pulls out of the flesh and remains attached to the pedicel.

Pedicel. The divisions or branches of the peduncle.

Peduncle. A flower stalk; the stem that supports the flowers or fruit.

Pigment. Opaque coloring matter deposited in the plant cell or tissue.

Raphe. The seamlike union of two halves of an organ; in anatropous ovules, that part of the funicle adnate to the integument forming a ridge 


\section{GLOSSARY}

along the body of the ovule. A medium line, or suture, between two pericarps. The line found on the seed of the grape.

Chalaza. The depression found near the center of the seed. The point at which the nucellus and integuments of the ovule are united.

\section{Special Terms for the Pear}

Neck. The narrow part toward the stalk. The neck may be long, narrow, short, obtuse, acute, distinct, or obscure.

Body. The larger part of the fruit toward the crown. The body may be small, large, oblate, round, conical, or ovate.

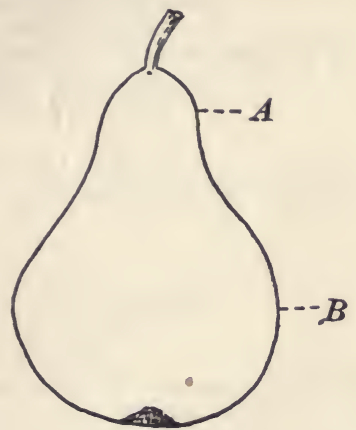

Fig. 51. $A$, neck; $B$, body

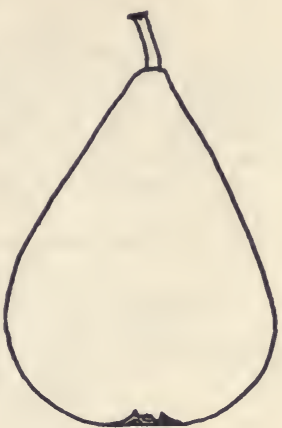

Frg. 52. Acute

Pyriform. A term used to describe the shape of a pear when the sides formed by the body and the neck are more or less concave, or hollowed out. Turbinate. Top-shaped, or having the body nearly round. 



\section{INDEX}

Absorption of water by seeds, 12

Alcoholic grafting-wax, 110

Ammoniacal solution of copper carbonate, 146

Amygdalus persica, 60, 62, 64

Amygdalus platycarpa, 64

Annular budding, 104

Apple, buds of, 66 ; pruning of, 80 ; systematic study of, 154-173

Arsenate of lead, 150

Bark grafting, 118, 122

Beeswax and resin grafting-wax, 108

Begonia, 36

Bigarreau, 54

Blackberry, 38

Brambles, pruning of, 90

Bridge grafting, 126

Bryophyllum, 36

Budding, shield, 94; prong, or twig, 96; plate, 98 ; H-, 100 ; flute, 102 ; ring, or annular, 104; chip, 104

Buds: Prunus domestica, 48; Prunus americana, 50; Prunus triflora, 50; Prunus hortulana, 52; Prinus munsoniana, 52; Prunus avium, 54, 56, 58 ; Prunus cerasus, 54, 58; Amygdalus persica, 60, 62, 64; Amygdalus platycarpa, 64; Malus sylvestris, 66; Pyrus communis, 68; Pyrus sinensis, 68; Cydonia vulgaris, 70; Vitis labrusca, 72 ; Vitis vinifera, 74

Bulbil, 28

Bulbs, 28

Bush fruits, pruning of, 92

Cactus, 32

Carnation, 32

Chemicals, effect on germination' of seeds, 20

Cherry, buds of, $54,56,58$; pruning of, 84

Chip budding, 104

Chrysanthemum, 32

Cleft grafting, 118, 120

Coleus, 32

Commercial fertilizers, effect on seeds, 24

Corms, 30

Crocus, 30

Currant, 40, 42

Cuttings, soft or green wood, 32,34 ; leaf, 36 ; root, 38 ; hardwood, or dormant, 40 ; one-eye, two-eye, threeeye, 44 ; mallet, 44,46 ; heel, 44,46
Dicotyledons, 18

Dinner-plate seed-tester, 2

Dormant cuttings, $\mathbf{4 0}$

Double-whip grafting, 116

Drought, effect on germinating seeds, 18

Flute budding, 102

Fungicides : effect on seeds, 26 ; Bordeaux mixture, 132 ; lime-sulphur, $138,140,142$; self-boiled lime-sulphur, 144; ammoniacal solution of copper carbonate, 146

Geneva seed-tester, 2, 4, 8

Geranium, 32

Germinating chamber, 2

Germinating cup, 2

Germination, hastened by soaking, 16

Gladiolus, 30

Gloxinia, 36

Gooseberry, 40, 42

Grafting, splice, 112 ; whip, or tongue, 114 ; double-whip, 116 ; cleft, 118 , 120 ; bark, 118,122 ; bridge, 126 ; side, 128 ; veneer, 130

Grafting-cord, 108

Grafting-wax, 108, 110

Grape, cuttings of, 44,46 ; buds of, 72,74 ; pruning of, 88 ; systematic study of, 174-185

Green wood cuttings, 32, 34

Hardwood cuttings, 40, 42, 44

H-budding, 100

Heel cutting, 44, 46

Horse radish, 38

Hyacinth, 28

Hydrangea, 34

Hypothesis, 20, 21

Insecticides : Paris green, 148; arsenate of lead, 150 ; lime-sulphur, 138, 140, 142; self-boiled lime-sulphur, 144 ; kerosene emulsion, 152

Kerosene emulsion, 152

Leaf cuttings, 36

Lily, 28

Lime-sulphur, 138 ; self-boiled, 144

Mallet cutting, $\mathbf{4 4 ,} 46$

Monocotyledons, 18

Morello, 58 


\section{LABORATORY MANUAL OF HORTICULTURE}

Oleander, 32

One-eye cutting, 44

Onion, 28

Paris green, 148

Peach, buds of, 60,62, 64; pruning of, 86 ; systematic study of, $186-197$

Pear, buds of, 68 ; pruning of, 82 ; systematic study of, 198-209

Pitch wax, 110

Plate budding, 98

Plum, buds of, $48,50,52$; pruning of, 84 ; systematic study of, 210,221

Pomaceous fruits, 66

Prong budding, 96

Quince, buds, 70

Ring budding, 104

Root cuttings, 38

Rose, 32

Scion, 122

Seed vitality limited by age, 10

Seed-testers, 2

Seed-testing, 6

Seeds, amount of water absorbed by, 12; determining volume of, 12 ; germination of, 16 ; of dicotyledons,
18; effect of drought on, 18; of monocotyledons, 18 ; treated with chemicals, 20 ; effect of commercial fertilizers on, 24

Shield budding, 94

Side grafting, 128

Soaking of seeds, 16

Soft wood cuttings, 32

Splice grafting, 112

Sprouting-chamber, 6

Systematic study, of apple, 154-173; of grape, $174-185$; of peach, 186197 ; of pear, 198-209; of plum, 210-221

Three-eye cutting, 44

Tile germinator, 2,4

Tongue grafting, 114

Tulip, 28

Twig budding, 96

Two-eye cutting, 44

Veneer grafting, 130

Vine fruits, 72

Vitis labrusca, 72

Vitis vinifera, 74

Volume of seeds, 12

Whip grafting, 114 



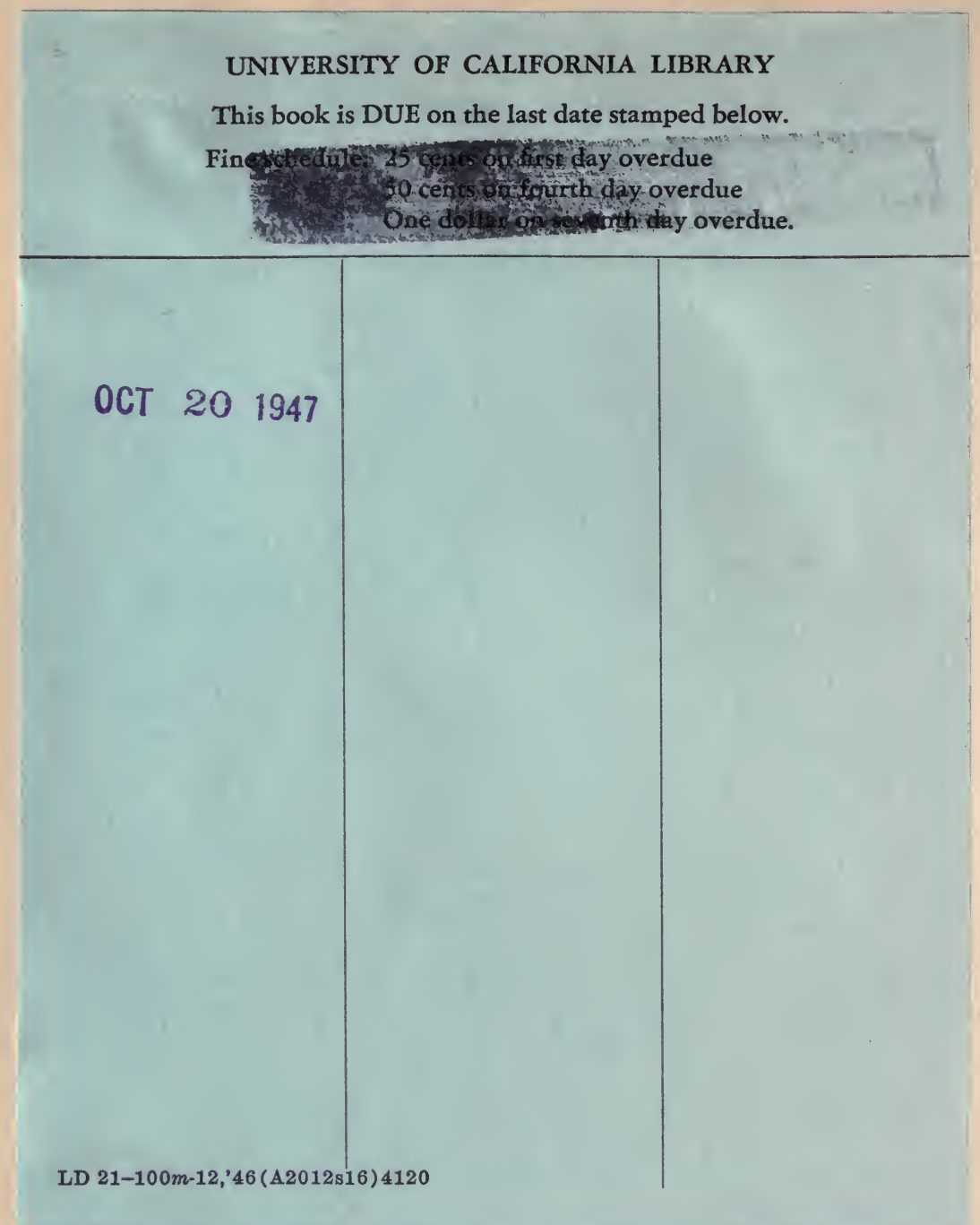




\section{YC 62059}

xy

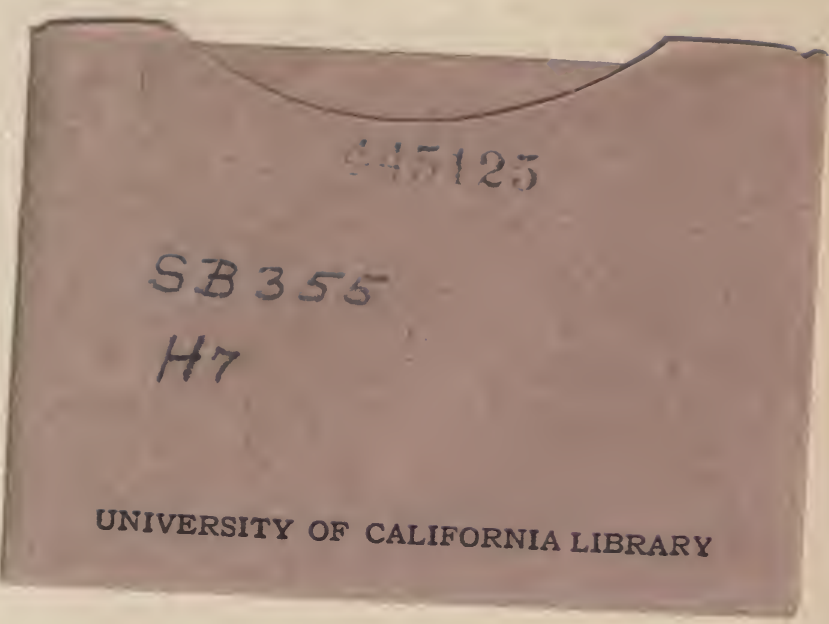


